\title{
3. EL REFERÉNDUM EN EL SISTEMA CONSTITUCIONAL ESPAÑOL
}

\author{
JOAN OLIVER ARAUJO \\ Universidad de las Islas Baleares
}




\section{SUMARIO}

I. ALgUNAS CONSIDERACIONES INTRODUCTORIAS EN TORNO A LA INSTITUCION DEL REFERENDUM.-1. Democracia representativa y democracia directa: ¿complementariedad o antagonismo?. 2. Concepto y evolución histórica del referéndum. 3. Clases de referéndums. 4. La crítica al referéndum y las condiciones necesarias para lograr su validez democrática.-II. LA INSTITUCIÓN DEL REFERÉNDUM EN EL SISTEMA CONSTITUCIONAL ESPAÑOL.-1. Clases de referéndums previstos en el ordenamiento juridico español. 1.1. Cuestiones preliminares. 1.1.1. El referéndum en el proceso constituyente. 1.1.2. Normativa reguladora de la institución del referéndum. 1.2. Referéndums de reforma constitucional. 1.2.1. Introducción. 1.2.2. Modalidades del referéndum de reforma constitucional. 1.2.2.1. Referéndum de reforma constitucional facultativo (art. 167). 1.2.2.2. Referéndum de reforma constitucional obligatorio (art. 168). 1.2.3. Algunas cuestiones procedimentales en torno a los referéndums de reforma constitucional. 1.3. Referéndum consultivo (art. 92). 1.3.1. Introducción. 1.3.2. Procedimiento que debe seguirse para convocar un referéndum consultivo. 1.3.3. Objeto de la consulta: «decisiones politicas de especial trascendencia". 1.2.4. Alcance y significado del término "consultivo" aplicado a esta modalidad de referéndum. 1.4. Referéndums autonómicos. 1.4.1. Introducción. 1.4.2. Referéndum para que una proyectada comunidad autónoma pueda acceder a la autonomía plena por la via rápida sin reunir los requisitos que exige la disposición transitoria segunda (art. 151-1). 1.4.3. Referéndum para aprobar los estatutos de autonomía de los territorios que sigan la vía rápida (art. 151-2). 1.4.4. Referéndum para modificar los estatutos de autonomia de las comunidades autónomas que hayan seguido la vía rápida (art. 152-2). 1.4.5. Referéndum para la incorporación de Navarra a la Comunidad Autónoma Vasca (disposición transitoria cuarta). 1.5. Referéndum municipal. 2. El extraordinario protagonismo de los partidos políticos en los procesos referendarios. Valoración crítica. BIBLIOGRAFIA EN TORNO A LA INSTITUCION DEL REFERENDUUM. 
Revista de Derecho Político, núm. 29, 1989, pp. 115-182

\title{
3. EL REFERÉNDUM EN EL SISTEMA CONSTITUCIONAL ESPAÑOL
}

\author{
POR \\ JOAN OLIVER ARAUJO \\ Universidad de las Islas Baleares
}

I. ALGUNAS CONSIDERACIONES INTRODUCTORIAS EN TORNO A LA INSTITUCIÓN DEL REFERÉNDUM

1. Democracia representativa y democracia directa: ¿complementariedad 0 antagonismo?

Aunque no podemos ni debemos entrar en el estudio en profundidad de las nociones de "democracia representativa» y «democracia directa", ni tampoco en las relaciones entre ambos conceptos, temas de por sí todos ellos muy complejos, sí que creemos conveniente, para poder centrar correctamente el objeto de nuestra exposición, hacer una somera referencia a dichas nociones que, en alguna medida, son básicas dentro de la teoría constitucional.

Como ha afirmado con acierto el profesor AGUIAR DE LUQUE ', utilizando la terminologia del profesor Jorge DE ESTEBAN ${ }^{2}$, el pensamiento liberal, desde sus orígenes, se vio «escindido en dos versiones inicialmente irreconciliables» de participación política: «la participación directa y la participación representativa.»

1977, p. 4

- Cfr. Luis Aguiar de Luque: Democracia directa y Estado constitucional, Edersa, Madrid español», en Cuadernos para el Diálogo, número extraordinario XXXV, junio, 1973. 
a) El sistema representativo, como es sabido, se basa «en la sustitución del pueblo como teórico soberano por minorías que actúan en su nombre en virtud generalmente de un procedimiento electivo" ${ }^{3}$. El fundamento de dicho sistema, que tiene en Montesquieu y Sieyès sus primeros teóricos, consiste en identificar la voluntad de los representados con la de los representantes. MONTESQUIEU, en EI espiritu de las Leyes, defiende la total conveniencia del sistema representativo, argumentando que el pueblo está incapacitado "para tomar personalmente decisiones" de índole política ${ }^{4}$; y SIEYĖS irá todavía más lejos, elevando «la representación a la categoría de elemento esencial del concepto de nación» ${ }^{5}$.

b) Frente a la democracia representativa, se levanta doctrinalmente la democracia directa, que puede ser definida como «aquel régimen político en que la adopción de decisiones de interés general para la comunidad corresponde a la totalidad de los ciudadanos, que se pronuncian respecto a ellas de modo personal e individualizado, esto es, el clásico

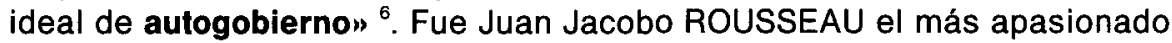
defensor de dicho modelo político, argumentando que la libertad sólo es posible en aquellas comunidades en donde la representación no es necesaria, pues - a su juicio- «desde que un pueblo delega su soberanía en representantes, pierde libertad y soberanía" ${ }^{7}$. Rousseau, como ha afirmado el profesor AGUIAR ${ }^{8}$, condenaba «el sistema representativo al rechazar el principio que le sirve de fundamento", esto es, «la idea de que la voluntad de una Asamblea elegida por los ciudadanos puede ser la voluntad del pueblo»; y, al mismo tiempo, "sentaba las bases para la participación directa». No debe olvidarse que para Rousseau la voluntad general soberana es «inalienable» $y$, en consecuencia, no puede ejercitarse a través de unos representantes, por tanto es indispensable que todos los ciudadanos participen directamente en la elaboración y aprobación de las leyes ${ }^{9}$. «El pueblo inglés — dirá Rousseau-cree ser libre, pero se engaña:

3 Cfr. José María Elizalde Pérez en el trabajo colectivo Apuntes de Derecho Político 1, Universidad de Extremadura, Facultad de Derecho, Departamento de Derecho Político, Cáceres. 1979-1980, vol. II, p. 64.

4 Cfr. Barón de Montesquieu: De l'Esprit des Lois, libro II, cap. 2. Citado por Luis AguiAR DE LUQUE: Democracia..., op. cit., p. 22.

5 SiEYE en su conocida obra ¿Qué es el Tercer Estado? se pregunta: “¿Qué es una Nación? Un cuerpo de asociados que viven bajo una ley común y representados por la misma legislatura". Citado por Luis AGUIAR de LuQUe: Democracia..., op. cit., p. 28.

6 Cfr. Luis Aguiar de Luque: Democracia..., op. cit., p. $3 \uparrow 1$.

Cfr. José María Elizalde Perez: Apuntes..., op. cit., p. 66.

- Cfr. Luis Aguiar de LuQue: Democracia..., op. cit., pp. 25-26.

9 Cfr. Luis SÁnChez Agesta: «Prólogo» a la obra de Luis AgUIAR DE LuQUe, Democracia directa y Estado Constitucional, Edersa, Madrid 1977, p. XX; Antonio TORRES DEL MORAL: “Democracia y representación en los orígenes del Estado constitucional", en Revista de Estudios Politicos, núm. 203, 1975, p. 152; Luis Agular de Luque: Democracia..., op. cit., pp. $26-27$. 
lo es sólo durante la elección de los diputados, volviendo luego a la esclavitud, a la nada» ${ }^{10}$.

No obstante lo anterior, hoy es opinión generalizada que este ideal de autogobierno, apasionada y brillantemente defendido por Rousseau, es totalmente impracticable en comunidades políticas extensas, en donde la complejidad de la vida moderna comporta la necesidad de adoptar decisiones rápidas y altamente tecnificadas, que no pueden someterse constantemente a la deliberación y fallo de todos los ciudadanos. Precisamente por estos motivos, los Estados modernos, prácticamente sin excepción, se han organizado de acuerdo con el principio representativo.

En la primera etapa del liberalismo, como ya hemos indicado, democracia directa y Estado representativo se concibieron como dos modelos incompatibles y contrapuestos ${ }^{11}$. Sin embargo, tras la generalización del sistema representativo y el consiguiente olvido del modelo de democracia directa, por las razones que hemos apuntado, se dejó sentir progresivamente la necesidad de ampliar los cauces de participación del ciudadano en la vida política. EI marqués de CONDORCET refleja gráficamente esta tensión dialéctica, al afirmar que el sistema político deseable es «aquel en el que tiene cabida el máximo de participación directa compatible con una Constitución representativa» ${ }^{12}$. Haciendo un notable esfuerzo de síntesis, Condorcet «mostrará la utilidad de una adecuada combinación de la tesis rousseaunianas con el sistema representativo, configurando las primeras instituciones de participación directa en un marco constitucional» ${ }^{13}$.

A tenor de lo anterior, podemos concluir que «si en el mundo contemporáneo el gobierno representativo sigue siendo modelo irremplazable, el desarrollo tecnológico parece haber propiciado unas posibilidades para las instituciones de participación directa que no es posible desconocer " ${ }^{14}$. Sin olvidar además que, tal como ha señalado la doctrina unánimemente ${ }^{15}$, los instrumentos de participación directa complementan los mecanismos tradicionales de la democracia representativa, y les aportan "un plus de legitimidad» ${ }^{16}$.

10 Cfr. Antonio Torres del MORAL: «Democracia y...», op. cit., p. 165.

11 Cfr. Luis Aguiar de Luque: Democracia..., op. cit., pp. 311-312.

12 Citado por Antonio ToRres del Moral en su obra Principios de Derecho Constitucional español 1, Atomo Ediciones, Madrid 1985, p. 70.

13 Cfr. Luis Aguiar de LuQue: Democracia..., op. cit., p. 29.

${ }^{14}$ Cfr. Luis AguIAR DE LUQUE: "Referéndum», en Diccionario del sistema político español (dirigido por J. J. González Encinar), Akal, Madrid 1984, p. 791.

15 Cfr., entre otros, Adolfo HERNANDEZ LAFUENTE: «Los referéndums de autonomia en la II República", en Revista de Estudios Politicos, núm. 5, de 1978, p. 98; María Rosa Ripollés SERRANO: «Notas acerca de la Ley Orgánica sobre regulación de las distintas modalidades de referéndum", en Comentarios sobre la Constitución española de 1978, Universidad de Valencia, Valencia 1980, p. 315; Luis SANCHEZ AgeSTA: «Prólogo», op. cit., p. XIX.

${ }_{10}$ Cfr. Antonio TORRES Del MORAL: Principios..., op. cit., p. 64. 
Tras haber expuesto, en apresurada sintesis, el tema de las relaciones entre participación directa y participación representativa en términos generales, queremos analizar cómo se planteó esta cuestión en nuestro último proceso constituyente y cuál fue la solución finalmente adoptada en el Texto Constitucional. La discusión en el Congreso de los Diputados de los artículos referentes a la iniciativa popular y al referéndum provocó varios debates de alto nivel en torno a los «dos grandes principios políticos de representación y de participación» ${ }^{17}$. Lo que en el fondo se dilucidaba en los mismos era determinar en qué grado los instrumentos de participación directa debían "sobresalir en el juego político o ser meros correctores de la democracia representativa" ${ }^{18}$. $Y$ hemos de afirmar que aunque el Anteproyecto de Constitución recogía una amplia gama de modalidades de participación directa, durante el proceso parlamentario fueron sensiblemente cercenadas, ante el temor de que fueran utilizadas demagógicamente por grupos minoritarios, y ante la imperiosa necesidad de consolidar y fortalecer los partidos políticos tras cuatro décadas de gobierno autoritario. En resumen, pues, a pesar de la oposición del diputado Fraga Iribarne y de su Grupo Parlamentario, los constituyentes optaron «por un total predominio» de las instituciones de derrocracia representativa» ${ }^{19}$.

Esta clara opción a favor de la democracia representativa aparece, sin embargo, algo disfrazada en el artículo 23 de la Constitución, al afirmar que “los ciudadanos tienen el derecho a participar en los asuntos públicos, directamente o por medio de representantes, libremente elegidos en elecciones periódicas por sufragio universal». Y digo que este artículo es algo engañoso porque puede hacer pensar que estamos ante una "constitución mixta», que «pretende armonizar el principio representativo con el ejercicio" de amplias formas de democracia directa ${ }^{20}$, cuando en realidad lo que se ha consagrado es un sistema casi exclusivamente representativo. La Constitución de 1978, como afirma el profesor GARRORENA MORALES, responde "a una filosofía o concepción de la democracia que está - para decirlo apretadamente- más cerca de Montesquieu que de Rousseau, más próxima a la confianza en los representantes y a la traslación incondicionada de la propia capacidad de participar, que al ejercicio directo de dicha capacidad" ${ }^{21}$. Esta opción del constituyente comporta, como ha indicado el profesor RAMÍREZ ${ }^{22}$, que el juego político queda prácticamente monopo-

1T Cfr. Oscar Alzaga Villaamil: La Constitución española de 1978, Ediciones del Foro, Madrid 1978, p. 585.

1a Ibidem.

19 Cfr. Antonio TORRes del MORAL: Principios..., op. cit., p. 108.

20 Cfr. Pedro CRUZ VILLALÓN: «El referéndum consultivo como modelo de racionalización constitucional», en Revista de Estudios Políticos, núm. 13, 1980, p. 165.

21 Cfr. Ángel GarRoRena MORAles: El Estado español como Estado social y democrático de Derecho, Tecnos, Madrid 1984, p. 148.

22 Cfr. Manuel Ramirez JiméneZ: La participación politica, Tecnos, Madrid 1985, pp. 51$52,54-55,66,117$ y 147; Idem. «Democracia directa y Constitución: problemática y desarrollo 
lizado por los partidos políticos; lo cual, por otra parte, ya podía deducirse del tenor literal con que el artículo 6 los incorpora a nuestro sistema constitucional ${ }^{23}$.

Sentadas las anteriores afirmaciones, hay que añadir que en nuestro ordenamiento constitucional también se recogen, aunque de forma extremadamente cautelosa y restrictiva, algunos instrumentos de participación directa, que, siguiendo al profesor Jorge DE ESTEBAN ${ }^{24}$, podemos sistematizar en cuatro apartados ${ }^{25}$ :

a) La participación directa de carácter local: los concejos abiertos (art. 140).

b) La participación directa en el ámbito legislativo: la iniciativa legislativa popular (art. 87-3) y las peticiones a las Cámaras (art. 77).

c) La participación directa a través del referéndum (arts. 62-c, 92, $149-1-32 .{ }^{a}, 151,152,167,168$ y disposición transitoria $\left.4 .{ }^{a}\right)$.

d) La participación directa en el ámbito judicial: la acción popular, la participación a través de la institución del jurado y la participación en los tribunales consuetudinarios y tradicionales (art. 125).

Como se ve, el referéndum, objeto central de nuestro análisis, es uno de los mecanismos de participación directa del ciudadano en la vida

legislativo", en El desarrollo de la Constitución española de 1978, Pórtico, Zaragoza 1982, pp. $19-20$ y 33.

${ }_{23}$ El artículo 6 de la Constitución está redactado con el siguiente tenor: «Los partidos politicos expresan el pluralismo político, concurren a la formación y manifestación de la voluntad popular y son instrumento fundamental para la participación política». Es la expresión que hemos subrayado la que, tal como afirma el profesor Manuel Ramirez (La participación..., op. cit., pp. 54-55), «barruntaba cómo iban a ir las cosas».

${ }_{24}$ Cfr. Jorge DE ESTEBAN, en la obra colectiva: El régimen constitucional español 1, Labor Universitaria, Barcelona 1980, pp. 88-102.

${ }_{25}$ Incluimos en esta breve clasificación únicamente «las formas de participación política directa en sentido estricto" (Torres del Moral) y, en consecuencia, dejamos fuera otras que, aun constituyendo en alguna medida formas de participación directa, se mueven, sin embargo, "en un ámbito cualitativamente distinto" (Cruz Villalón). Entre estas últimas podemos citar las siguientes: la participación en la enseñanza (art. 27-5 y 7); la participación «de la juventud en el desarrollo politico, social, económico y cultural» (art. 48); la participación de los consumidores y usuarios, mediante sus organizaciones específicas, en aquellas cuestiones que puedan afectarles (art. 51-2); la participación de los ciudadanos en la Administración (art. 105-a, b y c); la participación de los ciudadanos «en la Seguridad Social y en la actividad de los organismos públicos cuya función afecte directamente a la calidad de la vida o al bienestar general» (art. 129-1); y la participación de los trabajadores en la empresa (art. 129-2). 
política, que le permitirá —al menos a nivel teórico- incidir en ella sin pasar por el tamiz de los partidos políticos.

\section{Concepto y evolución histórica del referéndum}

\section{a) Concepto}

El término "referéndum» aparece en los Parlamentos medievales, especialmente en Suiza. Se utilizaba para designar la técnica a través de la cual los representantes de los territorios, cuando sobre un tema carecian de instrucciones concretas, no tomaban sus decisiones en firme, sino ad referendum, es decir, “refiriendo el asunto a sus mandantes» y bajo la reserva de su ratificación ${ }^{26}$.

La utilización técnica del vocablo «referéndum» en nuestro país es relativamente reciente. El «Discurso leído el día 9 de noviembre de 1895 en el Ateneo Científico y Literario de Madrid sobre el tema del referéndum" ${ }^{27}$. por Segismundo Moret y Prendergast, más tarde Presidente del Gobierno, es, sin duda, una de las primeras ocasiones en que este término es utilizado en un ámbito académico. Tres años más tarde, Ángel GANIVET, en sus Cartas finlandesas, conceptúa al referéndum como un tema de moda ${ }^{28}$. Sin embargo, hasta 1917 no se publica en España un trabajo científico dedicado especificamente a este mecanismo de participación directa, en concreto me estoy refiriendo al libro de Julián DE REPARAZ y ASTEIN titulado, precisamente, El referéndum ${ }^{29}$. Añadamos, para concluir estas breves ideas sobre la introducción del vocablo "referéndum» en España, que en el Diccionario Manual de la Real Academia de 1927 se incluye, por primera vez, "una definición de referéndum como consulta que se hace al pueblo sobre asuntos de interés común» ${ }^{30}$.

Ofrecer una definición precisa de lo que debe entenderse por «referéndum» no es una tarea exenta de dificultades, pues, como tendremos ocasión de estudiar con detenimiento, existe una pluralidad de modalidades de referéndums, con requisitos y efectos específicos. Esta polémica institución, que constituye «un verdadero exponente de las tensiones y contra-

26 Cfr. Antonio Torres del Moral: Principios..., op. cit., p. 106; Luis AgUiAR de LuQue: Democracia..., op. cit., pp. 50-51; Adolfo HERNANDEZ LAFUENTE: “Los referéndums...», op. cit., p. 98; H. Duval: Référendum et Plébiscite, Armand Colín, Paris 1970, p. 6; Nicolás Pérez SERRANo: Tratado de Derecho Politico, Civitas, Madrid 1976, p. 700.

${ }_{27}$ Esti. Imp. Sucesores de Ribadeneyra, Madrid 1895.

${ }_{28}$ Cfr. Ángel Ganivet: Cartas finlandesas, Madrid 1898, p. 31. Citado por Luis AguIAR de LuQue: Democracia..., op. cit., p. 240.

29 Hijos de Reus, Madrid 1917.

30 Citado por Luis Aguiar de Luque: Democracia..., op. cit., p. 243. 
dicciones que traspasan al Estado de Derecho democrático" ${ }^{31}$, permite, ocasionalmente y bajo ciertas condiciones, ejercer la soberanía al pueblo, "depositario último de la misma», de modo que sus resultados se impongan, sin excepción, a todos los órganos del Estado ${ }^{32}$. En una primera aproximación, podemos definir el referéndum diciendo que es uno de los mecanismos de participación directa del ciudadano en la vida política, consistente en formular una pregunta al cuerpo electoral para que éste se pronuncie, con un sí o un no, sobre la misma, sin ningún tipo de intermediarios. Gilbert BORTOLI, en un notable trabajo sobre la práctica del referéndum en Francia, nos da la siguiente definición: «procedimiento por el que el conjunto de los ciudadanos se pronuncia directamente sobre una cuestión de gobierno (texto o medida puesta en acción o que se está a punto de poner), en lugar de que esta cuestión sea resuelta por los representantes de los ciudadanos y los poderes constituidos" ${ }^{33}$.

Las relaciones entre los términos "referéndum" y "plebiscito" han motivado numerosas páginas en la literatura científica, sin que se haya llegado a alcanzar un total acuerdo. El constiłucionalismo francés, sobre todo después de recibir la positiva experiencia Suiza antagónica a la vivida en Francia en las dos etapas napoleónicas ${ }^{34}$, empieza a distinguir entre referéndum y plebiscito, atribuyendo a este último un marcado tono peyorativo. En efecto, en el último cuarto del siglo XIX, surge en Francia «la necesidad de buscar una denominación para las consultas populares helvéticas en que se respetan los valores demoliberales por contraposición a la manipulación de dicho tipo de votaciones por el bonapartismo", que, siguiendo la tradición latina, se venian denominando plebiscitos ${ }^{35}$. Así, junto al término "plebiscito" empieza a usarse el de «referéndum», surgiendo entonces la célebre distinción entre «el buen referéndum y el mal plebiscito" ${ }^{36}$. Frente a ello, un importante sector de la doctrina alemana,

31 Cfr. Luis AguIAR de LUQUE: «Referéndum», op. cit., p. 791.

32 Cfr. Enrique LINDE PANIAgua y Miguel HerRero LeRA: «El referéndum en la Constitución española de 1978", en Boletín Informativo del Departamento de Derecho Politico, núm. 3, primavera 1979, p. 19. Paris 1965, p. 1.

${ }^{33}$ Cfr. Gilbert BonToLI: Sociología del referéndum en la Francia moderna, L.G.D.J.,

${ }_{34}$ Me estoy refiriendo, principalmente, a las «consultas populares" que se llevaron a cabo en tiempos de Napoleón I para establecer el Consulado vitalicio y el Imperio hereditario, y a las que se celebraron - cinco décadas más tarde- para legitimar el golpe de Estado de Napoleón III y proclamarle Emperador. Los resultados en todas las ocasiones «fueron abrumadoramente afirmativos, pues además de la elección adecuada del momento de la convocatoria, tampoco se ahorraron medios para presionar y condicionar el voto afirmativo. Jacques ELLUL, en relación a Napoleón I, indica algunos de los más significativos: violación del voto secreto mediante la votación pública sobre listas, votación por aclamación, computar como votos afirmativos las abstenciones, comunas en que se consideraban todos los votos afirmativos por el solo voto del alcalde, etc. Análogas presiones se podrían citar en relación a Napoleón III» (cfr. Luis AgUIAR DE LUQUE: Democracia..., op. cit., p. 61).

${ }_{35}$ Cfr. Luis Aguiar de LuQue: Democracia..., op. cit., pp. 315, 56-58 y 73-74.

36 Cfr. J. L. PARODY: La science politique, Paris 1971, p. 394. 
que ha tenido cualificados seguidores tanto en nuestro país ${ }^{37}$ como en Italia ${ }^{38}$, ha defendido la necesidad de superar el maniqueísmo francés. Para estos autores, «referéndum» y «plebiscito», aunque coinciden en la mecánica de preguntar al cuerpo electoral para que responda con un sí o un no, son dos figuras objetivamente diferentes. A su juicio, el referéndum es una votación popular que versa exclusivamente sobre la aprobación o rechazo de un texto legislativo. Por el contrario, el objeto de la consulta en el supuesto del plebiscito es una decisión política (vg. anexiones territoriales, adhesión a un régimen político y a su líder, acceso al autogobierno, disolución popular del Parlamento, resolución de conflictos entre órganos constitucionales, cuestiones de política internacional, etc.).

No obstante todo lo anterior, es preciso subrayar que en la actualidad hay una tendencia bastante generalizada, perceptible tanto en la doctrina como en la propia legislación, que propone dar idéntico significado a los términos «referéndum» y «plebiscito» ${ }^{39}$. Lo cual, después de todo, no es de extrañar, pues, como ha afirmado PARODY, se trata de una distinción "históricamente reciente» e “intelectualmente confusa" ${ }^{40}$.

En la Constitución de 1978 se utiliza casi exclusivamente el término referéndum ${ }^{41}$, que engloba tanto las consultas populares sobre temas legislativos (vg. arts. 167 y 168) como sobre decisiones políticas (vg. arts. 92 y 151-1). Tan sóio en la disposición transitoria segunda, refiriéndose a las consultas populares celebradas durante la Segunda República, emplea el vocablo plebiscito ${ }^{42}$. Sin embargo, no es dudable que, en el contexto de nuestra Constitución, este término, desprovisto ya de cualquier significado peyorativo ${ }^{43}$, puede identificarse plenamente con el de referéndum.

'37 Cfr. Nicolás Perez Serrano: Tratado..., op. cit., pp. 701-704; Carlos Ruiz del Castillo: Manual del Derecho Politico, Reus, Madrid 1939, pp. 518 y siguientes.

3e Paolo BIscaretti di Ruffia (Derecho Constitucional, Tecnos, Madrid 1973, p. 425) indica que a pesar de que la doctrina y la legislación usan, con frecuencia, indistintamente "los términos de referéndum y plebiscito, este último... deberia más precisamente referirse a una manifestación del cuerpo electoral no actuada en relación a un acto normativo (como el referéndum), sino, más bien, respecto a un simple hecho o suceso (por ejemplo: Romano, MorTATI), concerniente a la estructura esencial del Estado o de su Gobierno...». El referéndum, como se desprende de lo anterior, «se concreta - para BISCARETTI- en una manifestación del cuerpo electoral respecto' a un acto normativo" (p. 422).

39 Juan Alfonso SANTAMARIA PASTOR ("Artículo 92», en Comentarios a la Constitución, Civitas; Madrid 1985, p. 1317) afirma que, "en cualquier caso, se trata de una cuestión académica»; y Luis SANCHEZ AGESTA ("Prólogo", op. cit., p. XIX) indica que el referéndum y el plebiscito, "como fórmulas de consulta directa al pueblo, prácticamente se confunden».

40 Citado por Antonio ToRres del Moral: Principios..., op. cit., p. 107.

41 Cfr. artículos 62-C, 92, 149-1-32. ${ }^{a}, 151-1,151-2,152-2,167$ y 168, así como la disposición transitoria $4 .^{\mathrm{a}}$

${ }_{42}$ Disposición transitoria 2.": «Los territorios que en el pasado hubiesen plebiscitado afirmativamente proyectos de Estatuto de Autonomía...".

43 Tampoco en la legislación republicana se atribuyó al término "plebiscito" la tradicional carga peyorativa. Cfr. Juan M. LABOA y FrancisCo J. VANACLOCHA: «El referéndum en España», en Historia 16, núm. 7, noviembre 1976, p. 24. 


\section{b) Evolución histórica}

Cuando se investigan los antecedentes históricos de una institución jurídica moderna es imprescindible una actitud de "autolimitación", al objeto de no remontarse hasta figuras pretéritas que sólo muy remotamente pueden guardar alguna conexión con el instituto que se desea estudiar ${ }^{44}$. Por lo que respecta al referéndum, debemos precisar que aunque es posible hallar ciertas analogias con el plebiscitum (plebis-scitum) romano ${ }^{45}$ y con la técnica utilizada en los Parlamentos medievales para asegurar la constante coincidencia de voluntades entre los representantes y los representados ${ }^{46}$, lo cierto es que hasta el pensamiento liberal democrático y su intento de institucionalización a través de la Revolución Francesa no se puede hablar de referéndum en sentido moderno ${ }^{47}$.

En el Proyecto de Constitución francesa de 1793, básicamente elaborado por Condorcet, ya se introdujo el mecanismo de la consulta popular directa. Sin embargo, la realidad es que el siglo XIX supuso, para las instituciones de democracia directa, una auténtica "travesía del desierto" ${ }^{48}$. El referéndum no fue una excepción, y, o bien fue rechazado ante la general adopción del modelo político representativo ${ }^{49}$, o bien se utilizó fraudulentamente para legitimar situaciones de poder irregulares e incluso claramente antidemocráticas ${ }^{50}$. Tan sólo la Confederación Helvética, condicionada por sus peculiares circunstancias, irá introduciendo - en un contexto demoliberal- importantes mecanismos de participación directa, tanto en el marco federal como en el cantonal. Esta particularidad permitirá, ya en el último cuarto del siglo xIX, calificar al régimen suizo de «democracia semidirecta” ${ }^{51}$.

44 Con criterio análogo, cfr. Luis AgUIAR de LUQUE: Democracia..., op. cit., p. 19.

${ }_{45}$ En el Derecho Público romano se designaba con el término plebiscitum el decreto votado por la plebe a propuesta de su tribuno. En un principio los plebiscitos sólo obligaban a los plebeyos, pero a partir de la Ley Hortensia (286 a.C.) fueron asimilados a las leyes, vinculando entonces a todos los ciudadanos. Cir. Luis AgUIAR DE LUQUE: Democracia..., op. cit., pp. 19,56 y 240 .

${ }_{46}$ Como ya hemos indicado, el término referéndum se utilizaba para designar la técnica a través de la cual los representantes de los territorios, cuando sobre un tema carecían de instrucciones concretas, no tomaban sus decisiones en firme, sino ad referendum, es decir, "refiriendo el asunto a sus mandantes" y bajo la reserva de su ratificación. Cfr. supra nota (26).

47 Cfr. Julián Santamaria Ossorio: «Participación política y democracia directa», en Estudios de Ciencia Política y Sociología. Homenaje al profesor Carlos Ollero, Madrid 1972, p. 746.

48 Cfr. Luis Agular de LuQue: «Referéndum», op. cit., p. 791.

49 John Stuart MILL. (1806-1873), en el capitulo III Del gobierno representativo, expresa de manera muy gráfica la que es opinión generalizada en su época. Su razonamiento es del siguiente tenor: «puesto que en toda comunidad que exceda los límites de una pequeña población, nadie puede participar personalmente sino de una porción muy pequeña de los asuntos públicos; el tipo ideal de un gobierno es el gobierno representativo".

so Pensemos, por ejemplo, en los plebiscitos napoleónicos.

51 Cfr. Luis Aguiar de Luque: Democracia..., op. cit., p. 51. 
En los últimos decenios del siglo $\mathrm{xIx}$ y en los primeros del $\mathrm{xx}$ se publicaron numerosos trabajos sobre las instituciones de democracia directa y su posible combinación con el Estado representativo. Las causas principales de este novedoso interés por los mecanismos de participación directa, y especialmente por el referéndum, hay que buscarlas tanto en la buena prensa de la experiencia suiza, como sobre todo en las insuficiencias inherentes al Estado liberal clásico, especialmente para incorporar las masas populares a la vida política ${ }^{52}$. Sin embargo, en este contexto histórico, la introducción del referéndum no sólo pretendía satisfacer exigencias de tipo participativo, sino además mejorar el funcionamiento del sistema parlamentario, al objeto de superar la grave crisis política por la que atravesaba la Europa de entreguerras ${ }^{53}$. Con la constitucionalización del referéndum se pretendió «romper el circuito cerrado Gobierno-Parlamento, característico de la crisis del parlamentarismo» ${ }^{54}$, estructurando el proceso del poder sobre tres vértices: Gobierno-Parlamento-Pueblo ${ }^{55}$. El referéndum vendria asi «a introducir un tercer elemento en el proceso político, que exigía, además de la adecuación de los Gobiernos a los Parlamentos respectivos, la de ambos al electorado" ${ }^{56}$. Este nuevo planteamiento originaria el desarrollo de técnicas adicionales de participación política, «más allá de la, importante pero insuficiente, participación electoral» ${ }^{57}$. Fruto de esta amplia polémica doctrinal, y especialmente de las influencias de Max WE$\mathrm{BER}$, se introdujo el referéndum en la Constitución de Weimar ${ }^{58}$. A través de la cual pasó a diversas constituciones europeas del período de entreguerras (1919-1939), entre las que se encuentra la española de $1931^{59}$.

En Francia, en la misma época, se discutió ampliamente si la introducción de la figura del referéndum podía paliar la peligrosa inestabilidad gubernamental que afectaba a la Tercera República. Las opiniones no fueron coincidentes. ESMEIN negaba esta posibilidad, argumentando que la democracia directa y el Estado representativo son mecanismos políticos antagónicos, pues en tanto que aquélla deriva del principio de soberanía

52 LUIS AgUIAR DE LUQUE: Democracia..., op. cit., pp. 6, 50, 70, 71 y 112.

53 Cfr. Oscar Alzaga VIlLLaAmi: La Constitución..., op. cit., pp. 586-587.

54 Cfr. Luis Aguiar de LuQue: Democracia..., op. cit., p. 71.

55 Cfr. Julián Santamaria Ossorio: «Participación...», op. cit., p. 773.

so Cfr. Enrique Linde Paniagua y Miguel HeRRERo Lera: “El referéndum en la Constitución...", op. cit., p. 25.

Ibidem.

58 La Constitución de Weimar incorporaba, en un régimen parlamentario, una amplia gama de instrumentos de participación directa: iniciativa popular para someter a referéndum un proyecto de ley (art. 73-3), referéndum legislativo (arts. 72, 73-1, 73-2 y 75), referéndum de arbitraje (arts. 74 y 76), referéndum para la revocación del Presidente del Reich (art. 43) y referéndum para alterar las demarcaciones territoriales internas (art. 18). Cfr. Luis AGUIAR DE LUQUE: Democracia..., op. cit., pp. 89-105.

.59 Igualmente incorporaron algún tipo de referéndum la Constitución checoslovaca de 1920 (art. 46), la austríaca del mismo año (art. 43) y la del Estado Libre de Irlanda (arts. 47 y 50). 
popular, éste se vincula al principio de soberanía parlamentaria ${ }^{60}$. Frente a esta interpretación, CARRÉ DE MALBERG creía que la incorporación del referéndum podía favorecer un nuevo equilibrio político al limitar el poder del Parlamento, ya que, a su juicio, «el monopolio de la soberanía por el Parlamento era contradictorio con la necesidad de que la ley expresase la voluntad general» ${ }^{61}$. Mediante el referéndum, dirá Carré de Malberg, «el pueblo puede manifestar un sentimiento contrario a lo manifestado en su nombre por los representantes» ${ }^{62}$. Desde otra perspectiva, Maurice HAURIOU, en sus Principios de Derecho Público y Constitucional, también consideraba que no hay ningún inconveniente para "combinar la organización representativa de los Estados modernos con el referéndum inspirado en la democracia de los Estados antiguos". Más crítico en cuanto a la utilidad de esta combinación se mostró MIRKINE GUETZEVITCH, pues en su opinión el referéndum no es adecuado como «técnica para la libertad" ${ }^{63}$.

En los años posteriores a la Segunda Guerra Mundial, el referéndum fue ampliamente utilizado «como instrumento de legitimación y consenso para los nuevos regímenes constitucionales forjados a partir del vacío jurídico-político producido por la derrota militar del nazismo" ${ }^{64}$. Sin embargo, tras esta primera etapa de expansión, los mecanismos de participación directa languidecieron considerablemente, con las solas excepciones de la Confederación Helvética, en donde siguieron constituyendo un elemento esencial de su sistema político ${ }^{65}$, y de los primeros años de la $V$ República francesa, en donde el degolismo buscó por esta via el fortalecimiento de la figura del Jefe del Estado ${ }^{66}$. En nuestros dias, como afirma el profesor ALZAGA, el debate se ha ido complicando con numerosas aportaciones, «y el hecho es que, aunque en el terreno teórico han hecho importantes progresos los defensores de incrementar las vías de participación directa del pueblo, y más en concreto de extender los supuestos de consultas refe-

6o Cfr. A. Esmein: Elements de Droit Constitutionnel française et comparé, Paris 1921, vol. I, p. 425. Citado por Luis AgUIAR de LuQue: Democracia..., op. cit., p. 75.

Citado por Oscar Alzaga VillaAmil: La Constitución..., op. cit., p. 586.

62 Cfr. Raymond CARRE de MALBerg: «Considerations théoriques sur la question de la combinaison du référendum avec le parlementarisme", en Revue du Droit Public et de la Science Politique, núm. 2 de 1931, p. 232.

63 Cfr. Boris Mirkine Guetzevitch: Les nouvelles tendences du Droit Constitutionnel, Paris 1931, p. 165. Citado por Luis AgUIAR DE LUQUE: Democracia..., op. cit., p. 79.

Justificaba esta valoración afirmando que en aquellos países «en que por falta de educación política el electorado no es disciplinado, el Parlamento está más capacitado para tomar decisiones; en cambio, en los restantes países, el elector con su voto electoral se está pronunciando respecto a un programa, con la ventaja de que expresa su opción para varias medidas conjuntamente". Cfr. Luís Aguiar de LuQue: Democracia..., op. cit., p. 79.

64 Cfr. Luis Aguiar de LuQue: Democracia..., op. cit., p. 8.

65 Ibidem. p. 9.

68 Entre 1958 y 1972 fueron convocados en Francia seis referéndums. Cfr. Antonio Torres del moral: Principios..., op. cit., p. 72; Enrique Linde Paniagua y Miguel Herrero Lera: «El referéndum: de las Leyes Fundamentales al Anteproyecto de Constitución», en Revista de Estudios Políticos, núm. 2, 1978, p. 91. 
rendarias, en la práctica los pasos que se han dado en los países más avanzados de Occidente han sido cautos y, con frecuencia, de éxitos más que dudosos» ${ }^{67}$. En su oscilación, el péndulo político se encuentra hoy en una etapa de "recesión referendaria» " ${ }^{68}$, ya que, como indica el profesor CRUZ VILLALÓN, "la época de los entusiasmos indiscriminados por las supuestas manifestaciones directas de la voluntad popular pasó hace tiempo» 69 .

\section{Clases de referéndums}

Hay que iniciar este apartado recordando que todas las clasificaciones son convencionales, un modo de ir entendiéndose y de ordenar mínimamente el trabajo. La mia, sintesis de muchas otras ${ }^{70}$ y que por tanto no pretende tener el mérito de la originalidad, es necesariamente limitada e imperfecta:

a) Por la necesidad o no de que se celebre el referéndum para la validez del acto, puede ser obligatorio o facultativo ${ }^{71}$. Mientras que el primero «tiene lugar ope legis, por imperativo constitucional», el segundo sólo se celebra cuando lo requiere un órgano (o porción del mismo) legitimado para ello ${ }^{72}$. En España, por ejemplo, es referéndum obligatorio el que se precisa para llevar a cabo una reforma total de la Constitución (art. 168), y es facultativo el que puede celebrarse en el supuesto de una reforma parcial no esencial de la misma (art. 167).

b) Dentro del ámbito de los referéndums facultativos podemos hacer otra clasificación, en función de quién está legitimado para solicitar su convocatoria. Distinguimos entonces entre referéndums a iniciativa de un

at Cfr. Óscar Alzaga VILlaAmIL: La Constitución..., op. cit., p. 587. Con criterio análogo puede verse el trabajo del profesor Manuel RamlREz: La participación..., op. cit., p. 125.

${ }_{68}$ Cfr. M. Boulssou: «La pratique référendaire en France», en Revue Internationale de Droit Comparé, XXVIII, 2, 1976, pp. 265-286.

${ }_{69}$ Cfr. Pedro CRUz VILLALON: «EI referéndum...», op. cit., p. 167. Incluso en países como Italia en donde se recogieron una amplia gama de mecanismos de participación directa, se ha producido un "proceso de racionalización de los mismos», básicamente a través de la legislación ordinaria y de la interpretación constitucional.

70 Para elaborar esta breve clasificación hemos tenido en cuenta las que se han propuesto en los siguientes trabajos: Jorge DE ESTEBAN: El régimen..., op. cit., pp. 93-94; Antonio TORRES del MORAL: Principios..., op. cit., pp. 107-108; Luis AgUIAR DE LUQUe: Democracia..., op. cit., pp. 115, 116, 318 y 319; Pedro CRUz VILLALON: «El referéndum...», op. cit., pp. 146-147; Nicolás Pérez Serrano: Tratado..., op. cit., pp. 700-704; Paolo Biscaretti di RufFia: Derecho..., op. cit., pp. 422-426; María Rosa Ripollés SerRano: «Notas...», op. cit., pp. 321-322.

7 Con análogo criterio, cfr. Antonio ToRReS del MORAL: Principios..., op. cit., p. 107.

72 Cfr. Pedro CRuz VILLALON: «El referéndum...», op. cit., p. 146. 
determinado número de electores, a iniciativa del Gobierno o de su Presidente, a iniciativa del Jefe de Estado y a iniciativa del Parlamento o de una porción del mismo. En España, por ejemplo, es facultativo a instancia del Presidente del Gobierno el referéndum consultivo del art. 92, y es facultativo a propuesta de una porción del Congreso o del Senado el referéndum de reforma parcial no esencial de la Constitución.

c) Atendiendo al «conienido formal de la consulta" ${ }^{73}$, el referéndum puede ser normativo o no normativo. El primero, como es obvio, tiene por objeto una disposición normativa, el segundo, por su parte, versa sobre una decisión política ( $\mathrm{vg}$. anexiones o segregaciones territoriales, adhesiones a organismos internacionales, resolución de conflictos entre órganos constitucionales, etc.). Recordemos ahora que, tal como hemos indicado, un sector de la doctrina denomina plebiscitos a estos referéndums no normativos. En nuestro ordenamiento constitucional, es normativo el referéndum que se exige para aprobar los estatutos de autonomía de los territorios que sigan la vía rápida (art. 151-2), y es no normativo el referéndum que se exige para que una proyectada comunidad autónoma pueda acceder a la autonomía plena por la vía rápida sin reunir los requisitos que exige la disposición transitoria segunda (art. 151-1).

d) Los referéndums normativos, a su vez, pueden clasificarse en constitucionales y legislativos, en función del rango jerárquico de la norma que se somete al veredicto popular. En España, tiene carácter de constitucional el referéndum previsto en el artículo 168 para reformar la Carta Magna, por el contrario se han excluido de nuestro sistema político los referéndums legislativos propiamente dichos ${ }^{74}$.

e) Dentro de los referéndums legislativos, según que el texto normativo esfé o no en vigor, podemos distinguir entre referéndum legislativo de ratificación ${ }^{75}$ y referéndum legislativo abrogatorio. El primero de ellos, que es el referéndum legislativo en sentido estricto, consiste en someter a la decisión del cuerpo electoral un proyecto de ley (en consecuencia, si el resultado es afirmativo se convierte en ley, y si es negativo el proyecto no llega a entrar en el ordenamiento). El segundo, en cambio, tiene por objeto

73 En este caso utilizamos la gráfica fórmula del profesor Antonio TORAES DEL MORAL: Principios..., op. cit., p. 107.

${ }^{74}$ Debemos precisar, al objeto de evitar confusiones, que, en sentido literal, es "legislativo" el referéndum que se exige para aprobar el estatuto de autonomía de un territorio que siga la via rápida (art. 151-2), pues lo que se somete a la decisión popular es una norma con rango de ley (en concreto, orgánica). Sin embargo, este "referéndum autonómico", que guarda importantes analogías con el de reforma constitucional, responde a unos planteamientos muy distintos a los del referéndum legislativo propiamente dicho (cuyo objeto es aprobar o derogar una ley).

${ }_{75}$ Paolo BISCARETI dI RuffiA (Derecho..., op. cit., p. 422) utiliza en este supuesto la denominación referéndum «constitutivo». 
una ley ya en vigor en el momento de celebrarse el referéndum (en consecuencia, en función de cuál sea el resultado, la ley será derogada o mantendrá su vigencia). En el texto definitivo de nuestra Constitución fueron suprimidas, como ya hemos señalado, estas dos modalidades referendarias.

f) Atendiendo a la obligación de los poderes públicos de acatar el resultado, algunos autores han distinguido entre el referéndum vinculante y el meramente consultivo. Sin embargo, como tendremos ocasión de explicar, nos parece una distinción muy problemática, que precisa para ser aceptada de importantes aclaraciones.

g) En función del ámbito territorial en donde se celebra la consulta, podemos hablar de referéndums estatales (vg. los de reforma constitucional), referéndums regionales ( $\mathrm{vg}$. el previsto en el artículo 152-2 para reformar los estatutos de autonomía de las comunidades especiales) y referéndums municipales (vg. los previstos en el artículo 10-2 del Estatuto de Autonomía de Cataluña).

Como indicábamos al iniciar el estudio de la tipología referendaria, hay tantas clasificaciones como posibles perspectivas de análisis, lo que evidentemente obliga a una selección de las que se estimen más útiles e interesantes. Los siete puntos de vista que nosotros hemos utilizado, al habernos aportado un valioso material conceptual, nos facilitarán sensiblemente el análisis del referéndum en nuestro sistema constitucional.

\section{La crítica al referéndum y las condiciones necesarias para lograr su validez democrática}

El referéndum es una institución extremadamente polémica en la doctrina, lo cual no debe extrañar si se tiene en cuenta que ha sido utilizada con finalidades antagónicas y por “los regímenes políticos más dispares» ${ }^{76}$. En efecto, aunque en una primera impresión se podria pensar que el referéndum es el método de decisión democrático por excelencia, pues el pueblo decide sin ningún tipo de intermediarios, hay que ser muy precavidos antes de «pronunciarse sobre su santificación democrática" ${ }^{77}$. "La historia —como afirma Jorge DE ESTEBAN— nos enseña que han sido precisamente los enemigos de la democracia los que han utilizado con más

76 Cfr. Enrique Linde Paniagua: «Artículo 92. Referendum», en Comentarios a las Leyes Politicas. Constitución española de 1978 (dirigidos por Oscar Alzaga Villaamil), Edersa, Madrid 1985, tomo VII, p. 370.

${ }^{7}$ Cfr. Jorge de EsteBAN: El régimen..., op. cit., p. 92. 
frecuencia esta forma de consulta popular» ${ }^{78}$. Y Karl FRIEDRICH, en la misma línea, ha subrayado que «los plebiscitos constituyen uno de los métodos predilectos de los dictadores, buscando en su autoridad un fundamento legítimo" ${ }^{79}$. LOEWENSTEIN, con la fina perspicacia jurídica que caracteriza toda su obra, explica la razón de esta llamativa popularidad del referéndum entre los enemigos de la libertad. A su juicio, dicha razón hay que buscarla en «el hecho de que la votación de (un) referéndum se puede manipular con propaganda y presión mejor que el procedimiento" de elección de una "asamblea representativa, ciertamente más racional»"

En España tenemos varias experiencias de referéndums celebrados en un contexto autoritario ${ }^{81}$. La carencia absoluta de libertades, unida a una cuidada campaña oficial y a la imposibilidad de defender con eficacia respuestas distintas a la del partido único, convirtieron dichas consultas en un burdo mecanismo para legitimar ante la comunidad internacional un régimen político en el que el pueblo carecia de cualquier protagonismo.

Los reparos que, desde posiciones democráticas, se han formulado al referéndum pueden sintetizarse en tres puntos ${ }^{82}$ : primero, distinta lógica a la que responden la democracia representativa y el referéndum; segundo, facilidad de manipular el referéndum por quienes están en el Poder; y tercero, pérdida de utilidad y significado del referéndum en los regímenes políticos occidentales. Detengámonos, muy brevemente, en su análisis.

1) En primer lugar, se destaca la «distinta lógica» a la que responden la democracia representativa y el referéndum. Pues en tanto que aquélla se basa en la sustitución del pueblo por minorías que actúan en su nombre, éste constituye una clara manifestación de las concepciones democráticas radicales de Juan Jacobo Rousseau, críticas del sistema representativo y favorables al autogobierno. O dicho con otras palabras, en tanto que el Estado representativo se vincula al principio de soberanía parlamentaria, el referéndum deriva del principio de soberania popular ${ }^{83}$.

2) En segundo lugar, se afirma que el referéndum es, tal como demuestra la historia, fácilmente manipulable por quienes ocupan el Poder, y además favorece soluciones de carácter conservador, obstaculizando las decisiones de signo progresista. El primero de estos dos aspectos parece bastante indiscutible pues, desde Napoleón al general Pinochet, muchos

78 Jorge oeEsteban: El régimen..., op. cit. p. 92.

79 Cfr. Karl Friedrich: La démocratie constitutionnelle, P.U.F., París 1958, p. 513.

so Cfr. Karl Loewenstein: Teoría de la Constitución, Ariel, Barcelona 1976, p. 329.

ar En concreto, nos referimos a los plebiscitos de 1947 y 1966.

az Seguimos básicamente la exposición del profesor Luis AGUIAR DE LUQUE: «Referéndum», op. cit., pp. 791-792.

83 Cfr. A. EsMein: Elements..., op. cit., p. 425. 
dictadores lo han utilizado «para buscar - y forzar - un voto de adhesión incondicional» a su persona y a su sistema político ${ }^{84}$. Las predilecciones, por ejemplo, de Hitler, Franco o Nasser por el referéndum no han hecho sino aumentar los recelos con que es contemplada esta institución. Por lo que se refiere al segundo aspecto de esta crítica, esto es, que el referéndum favorece respuestas de carácter conservador, me parece ya más discutible ${ }^{85}$. El movimiento obrero francés, influido por las experiencias bonapartistas, participó durante muchos años de este recelo, hasta el extremo de rechazar decididamente la práctica referendaria ${ }^{86}$. A nuestro entender, esta crítica debe matizarse, pues el referéndum es conservador sólo en el sentido literal de la palabra, esto es, tiende a favorecer el mantenimiento del statu quo existente al tiempo de celebrarse la consulta (sea éste objetivamente de derechas o de izquierdas). $Y$ aún con esta precisión, esta crítica debe aceptarse con bastantes cautelas.

3) Finalmente, el profesor AGUIAR recuerda que para algunos autores el referéndum ha perdido todo significado en los sistemas políticos occidentales, ya que «las consultas electorales (sobre la base de la rigidez de las estructuras partidistas) se han tornado en una fórmula que conjuga la designación de gobernantes con la elección de opciones politicas alternativas» ${ }^{87}$. Dicho con otras palabras, cuando hay elecciones generales, y en la sociedad hay algún tema de especial trascendencia fuertemente controvertido (vg. legalización del aborto, ingreso en una estructura militar internacional, etc.), cada partido politico en su programa electoral debe pronunciarse sobre el mismo. De esta manera, cada ciudadano no sólo elige determinados gobernantes, sino que también, simultáneamente, opta por una u otra solución al tema objeto de la controversia. Siendo, por tanto, a juicio de estos autores, innecesario e incluso perturbador la introducción del referéndum.

A nuestro juicio, sin negar que algunos de los reparos que se han dirigido contra el instituto del referéndum son realmente preocupantes, parece fuera de toda duda el carácter genuinamente democrático del mismo ${ }^{88}$. Es cierto que su utilización ha servido con mucha frecuencia a regímenes políticos autocráticos y despóticos, pero también lo es que ni por su naturaleza ni por sus orígenes históricos se puede calificar al re-

"Cfr. Juan M. LaBOA y Francisco J. VANACLOCHA: «El referéndum...», op. cit., p. 24. Con análogo criterio, cfr. Jose María ElizALde Pérez: Apuntes..., op. cit., p. 68.

${ }_{85}$ En el mismo sentido, cfr. Luis AGUIAR DE LUQUE: «Referéndum», op. cit., p. 792.

B6 El líder socialista francés Jules Guesde sintetiza gráficamente este planteamiento con la siguiente frase: «entre el cólera, que es el régimen parlamentario, y la peste, que es el plebiscitario, no se elige: se dice que no a uno y a otro". Citado por Antonio TORRES DEL MORAL: Principios..., op. cit., p. 69.

${ }^{a 7}$ Cfr. Luis AguiAR DE LuQue: "Referéndum», op. cit., p. 792.

so Ibidem, p. 791. 
feréndum de antidemocrático, sino todo lo contrario ${ }^{89}$. «Sin dejar de reconocer, pues, la ambivalencia que en la práctica política ha comportado acudir a fórmulas referendarias, y siendo también conscientes de la dificultad que encierra el ejercicio de la democracia directa o semidirecta en los Estados contemporáneos, el referéndum nos sigue pareciendo no sólo una fórmula inserta en la legitimidad democrática», sino también "un instrumento útil en la toma de decisiones colectivas» que requieran un especial consenso ${ }^{90}$.

El profesor Jorge DE ESTEBAN, desde una perspectiva teórica, ha señalado las tres condiciones necesarias para lograr que el referéndum tenga "una validez realmente democrática» ${ }^{91}$. En primer lugar, es imprescindible que la consulta se lleve a cabo en un Estado de Derecho, con todas las garantias formales y materiales que esta fórmula politica implica. Esto comporta, como es obvio, «que el referéndum no es, ni puede ser, más que otra de las varias instituciones utilizables en una democracia en donde exista ya un pluralismo político y unos derechos fundamentales garantizados. Pero, en ningún caso, puede ser la única vía de participación popular» en la vida política ${ }^{92}$. En segundo lugar, es necesario que el referéndum recaiga sobre una materia adecuada y que la pregunta esté correctamente formulada. "Un referéndum mal planteado o excesivamente técnico no supondrá la aclaración del tema" controvertido, ni dará «legitimidad a la consulta" ${ }^{93}$. No es posible desconocer que la respuesta depende en gran medida «de los términos, más o menos hábiles, en que la interrogación al pueblo se haya formulado" ${ }^{94}$. Finalmente, en tercer lugar, para la validez democrática de las consultas referendarias, se exige un adecuado control de los medios de comunicación de masas de titularidad pública $y$, muy especialmente, de la televisión cuando ésta emite en régimen de monopolio ${ }^{95}$. En aras de la libertad de expresión, es imprescindible garantizar que las diversas organizaciones políticas, sociales, económicas, religiosas y culturales podrán acceder de forma equitativa a estos medios de comunicación públicos $\mathrm{y}$, al mismo tiempo, habrá que adoptar todas las

89 Opinión coincidente puede encontrarse, entre otros, en los siguientes trabajos: Enrique Linde Paniagua y Miguel HeRRero LeRA: «El referéndum en la Constitución...», op. cit., p. 28; Antonio TORRES DEL MORAL: Principios..., op. cit., p. 71.

9o Cfr. Enrique Linde Paniagua y Miguel Herrero Lera: «El referéndum en la Constitución...", op. cit., p. 24.

91 Cfr. Jorge de Esteban: El régimen..., op. cit., p. 92.

92 Ibidem.

93 lbidem.

94 El profesor Nicolás Pérez Serrano (Tratado..., op. cit., p. 703) plantea este tema entre interrogantes.

${ }_{95}$ Sobre el uso de los medios de comunicación de masas, cfr., entre otros, Jorge DE Esteban: Por una comunicación democrática, Fernando Torres editor, Valencia 1977; Jesús GARCIA JIMÉNEZ (compilador): Radiotelevisión española y la Constitución, Universidad Internacional Menéndez Pelayo, Madrid 1981; Miguel Angel AgulLaR (compilador): Los medios de comunicación en la frontera democrática, Universidad Internacional Menéndez Pelayo, Madrid 1982. 
medidas de control necesarias para que el Gobierno no use de ellos abusivamente.

\section{LAA INSTITUCIÓN DEL REFERÉNDUM EN EL SISTEMA CONSTITUCIO- NAL ESPAÑOL}

\section{Clases de referéndums previstos en el ordenamiento jurídico español}

\subsection{Cuestiones preliminares}

\subsubsection{El referéndum en el proceso constituyente}

La Constitución española de 1978, tras varios debates parlamentarios de alto nivel, ha consagrado tres grandes modalidades de referéndums (de reforma constitucional, consultivo y autonómicos), alguna de las cuales engloba a su vez varias subespecies perfectamente diferenciadas. EI referéndum de reforma constitucional puede ser, en función de la parte de la Ley Fundamental que se quiere modificar, facultativo (art. 167) u obligatorio (art. 168). El referéndum consultivo, que consiste en someter al veredicto popular "decisiones políticas de especial trascendencia», es único en su género (art. 92). Por el contrario, nuestra Constitución recoge, al menos, cuatro tipos de referéndums autonómicos: a) referéndum para que una proyectada Comunidad Autónoma pueda acceder a la autonomía plena por la via rápida sin reunir los requisitos que exige la disposición transitoria segunda (art. 151-1); b) referéndum para aprobar los estatutos de autonomia de los territorios que sigan la vía rápida (art. 151-2); c) referéndum para modificar los estatutos de autonomia de las Comunidades Autónomas que hayan seguido la vía rápida (art. 152-2); y d) referéndum para la incorporación de Navarra a la Comunidad Autónoma Vasca (disposición transitoria cuarta). A estas tres grandes modalidades de referéndums - constitucional, consultivo y autonómico- podemos añadir una cuarta: el referéndum municipal. Pues aunque la Constitución no la reconoce expresamente, parece clara su admisión en virtud de lo dispuesto en el artículo 149-1-32. ${ }^{a}$ de la misma ${ }^{96}$.

Esta pluralidad de tipos de referéndum que acabamos de enumerar es bastante engañosa, y no debe llevarnos a pensar que el mecanismo de las consultas populares directas tiene asignado un papel importante en

96 Análoga interpretación puede verse en Luis AGUIAR DE LUQUE: «Referéndum», op. cit., p. 798; Antonio Torres del Moral: Principios..., op. cit., pp. 110, 111 y 125. 
nuestro sistema político. Por el contrario, a lo largo del proceso constituyente se fue haciendo patente que, en los principales partidos políticos, existía una notable dosis de desconfianza hacia los instrumentos de participación directa en general, y hacia el referéndum en particular. El resultado ha sido que en el Texto Constitucional definitivo el referéndum ha aparecido sensiblemente devaluado en todos los sentidos, lo que, en principio, no parece muy de acuerdo con los amplios términos con que el artículo 23 consagra el derecho a participar directamente en los asuntos públicos $^{97}$.

Los aspectos más llamativos de esta desconfiada y restrictiva trayectoria constitucional son tres: la supresión del referéndum legislativo de ratificación y del referéndum legislativo abrogatorio, la restricción de los sujetos legitimados para solicitar la celebración de un referéndum y la calificación de "consultivo" al referéndum sobre decisiones políticas de especial trascendencia.

\section{1) Supresión del referéndum legislativo de ratificación y del referéndum legislativo} abrogatorio.

Lo más destacado del último proceso constituyente en lo que afecta a la institución del referéndum es, sin ninguna duda, la supresión del referéndum legislativo de ratificación y del referéndum legislativo abrogatorio, modalidades que, amén de gozar de cierta tradición en el Derecho comparado ${ }^{98}$, cuentan con algunos precedentes en el Derecho histórico

97 Cfr. Luis AguIAR DE LuQue: «La Ley Orgánica de Referéndum: Un comentario», en Revista de la Facultad de Derecho de la Universidad Complutense, núm. 58, 1980, p. 168; Idem: «Referéndum», op. cit., p. 793.

${ }_{98}$ El articulo 75 de la Constitución ítaliana recoge, con bastante detalle, el mecanismo del referéndum legislativo abrogatorio o derogatorio. El Presidente de la República debe convocar el referéndum «para decidir sobre la derogación (abrogazione) total o parcial de una ley o de un acto con fuerza de ley (esto es, un decreto-ley o una ley delegada) cuando lo soliciten 500.000 electores o cinco consejos regionales". Hay una serie de materias que, por su peculiar naturaleza, quedan excluidas de esta técnica: las leyes tributarias y presupuestarias, las de amnistia e indulto y las de autorización para ratificar los tratados internacionales. Precisamente para asegurar que estos límites sean respetados, la Ley reguladora de la Corte Constitucional, de 11 de marzo de 1953, otorga a este Tribunal la competencia para determinar qué peticiones de referéndum son admisibles y cuáles no en función de la materia. El derecho al sufragio en dichos referéndums se reconoce a todos los ciudadanos llamados a elegir la Cámara de Diputados. Además, para garantizar el respaldo popular a la propuesta de derogación, se exige que en la votación hayan participado la mayoría de los electores y que la posición favorable a la abrogación de la norma haya alcanzado la mayoría de los votos válidamente expresados (no computándose, en consecuencia, las papeletas en blanco o nulas). Cfr., entre otros, E. BETTINELLI: «Itineraria della razionalizzazione della convenzione antireferendaria», en Politica del Diritto, IX, 5, 1978, pp. 513-559; Pedro Cruz VILLALON: «El referéndum...", op. cit., pp. 151-152; Paolo BISCARETTI DI RuffIA: Derecho..., op. cit., pp. 423-424; 
español ${ }^{99}$. En efecto, tanto en el Anteproyecto de Constitución (BOC 5-I1978) como en el Informe de la Ponencia (BOC 17-IV-1978), el artículo que se corresponde con el número 92 del texto definitivo recogía tres clases de referéndums: sobre leyes aprobadas por las Cortes y aún no sancionadas, sobre decisiones políticas de especial trascendencia y sobre leyes en

U. Rescigno: «Referendum e istituzioni», en Politica del Diritto, IX, 5, 1978, pp. 605-627.

Por otro lado, el artículo 11 de la Constitución francesa de 1958 introduce, con importantes limitaciones, el referéndum legislativo de ratificación: «El Presidente de la República podrá, a propuesta del Gobierno durante los periodos de sesiones o a propuesta conjunta de las dos Cámaras, publicadas una u otra en el Diario Oficial, someter a referéndum cualquier proyecto de ley que se refiera a la organización de los poderes públicos, que entrañe la aprobación de un acuerdo de la Comunidad o tienda a autorizar la ratificación de un tratado que, sin ser contrario a la Constitución, pueda afectar al funcionamiento de las instituciones. Cuando el resultado del referéndum sea favorable a la adopción del proyecto, el Presidente de la República lo promulgará dentro del plazo previsto en el artículo anterior». Cfr., entre otros, Luis AgUIAR DE LUQUE: Democracia..., op. cit., pp. 149-183; Gilbert BorToli: Sociologia..., op. cit.; M. BouIssou: "La pratique...", op. cit., pp. 265-286; J. CADART: «Les inconvénients et les dangers plebiscitaires du référendum d'initiative présidentielle et gouvernementale en France dépuis 1958 et les remèdes désiderables", en Revue Internationale de Droit Comparé, XXVIII, 2, 1976; Jean-Marie GARRIGoU-LAGRANGE: «Le dédoublement constitutionnel. Essai de rationalisation de la pratique référendaire de la $V$ République", en Revue du Droit Public et de la Science Politique, núm. 4 de 1969, pp. 641-685.

${ }_{99}$ El artículo 66 de la Constitución republicana de 1931 introducía en nuestro ordenamiento la figura del referéndum legislativo, al afirmar que el pueblo podia "atraer a su decisión mediante referéndum las leyes votadas por las Cortes". Este mecanismo de participación directa -que nunca se utilizó pues ni siquiera se llegó a dictar la ley que debía regular su procedimiento y garantias - presentaba las siguientes características: 1. EI referéndum tenía por objeto «leyes votadas por las Cortes". Sin embargo, en su laconismo, aquel precepto no llegaba a precisar el plazo de que disponia el pueblo para poner en marcha este mecanismo $y$, en consecuencia, no quedaba claro si era un referéndum sobre leyes votadas por las Cortes y aún no promulgadas, o si, por el contrario, la consulta versaba sobre leyes ya en vigor. 2. ${ }^{a}$ La iniciativa correspondia exclusivamente al pueblo, en concreto debía solicitarlo el 15 por 100 del cuerpo electoral. Se trataba de una cifra bastante elevada (aproximadamente 1.900 .000 ciudadanos), con el fin de evitar la proliferación de este tipo de consultas directas. 3. ${ }^{a}$ Había una serie relativamente amplia de materias que no podian ser objeto de referéndum: “la Constitución, las leyes complementarias de la misma, las de ratificación de convenios internacionales inscritos en la Sociedad de Naciones, los Estatutos regionales" y «las leyes tributarias". $4 .{ }^{a}$ La regulación de este instituto se encomendó a una ley especial (art. 66 in fine) que, como ya hemos dicho, no llegó a dictarse a causa de las especiales circunstancias en las que se desarrolló la breve etapa republicana.

Por otra parte, ya en la autocracia franquista, la Ley de Referéndum Nacional de 22 de octubre de 1945 introdujo de nuevo la figura del referéndum legislativo, aunque en este nuevo contexto político la iniciativa se atribuía exclusivamente al Jefe del Estado. De acuerdo con el artículo primero de esta Ley, cuando la trascendencia de determinadas leyes lo aconsejase o el interés público lo demandase, el Jefe del Estado podia, "para mejor servicio de la Nación, someter a referéndum los proyectos de leyes elaborados por las Cortes". Precisar con claridad la naturaleza de este mecanismo de participación directa no es fácil, pues la Ley de Referéndum era técnicamente muy deficiente, y sus tres artículos, breves y confusos, parecian buscar intencionadamente la vaguedad (cfr. Enrique Linde Paniagua y Miguel Herrero Lera: "El referéndum: de las Leyes...", op. cit., pp. 94-95). Ello no obstante, podemos sintetizar en cuatro puntos sus rasgos jurídico-políticos más destacados: $1 .^{\circ}$ Se trataba de un referéndum facultativo (a diferencia del previsto en el artículo 10 de la Ley de Sucesión en la Jefatura del Estado) y no vinculante. $2 .^{\circ}$ Este referéndum - que sólo podía recaer sobre proyectos de leyes "elaborados" y aún no aprobados- estaba configurado como un trámite «excepcional en el 
vigor ${ }^{100}$. Sin embargo, al llegar a la Comisión de Asuntos Constitucionales del Congreso, la institución del referéndum sufrió una drástica restricción, fruto de una enmienda in voce del profesor Solé Tura consensuada entre todos los Grupos Parlamentarios a excepción del de Alianza Popular. El profesor Jordi Solé Tura al defender dicha enmienda, por la que se suprimian las dos modalidades de referéndum legislativo (el de ratificación y el abrogatorio), inició un interesante y denso debate que se prolongaría hasta el Pleno del Congreso de los Diputados. A su juicio, el referéndum sobre leyes aprobadas por las Cortes y aún no sancionadas «abre una extraña posibilidad de que la soberanía del Parlamento sea absolutamente menoscabada y establece, sobre todo, la posibilidad de conflictos muy serios entre Gobierno, Rey y Parlamento, puesto que se trata de leyes que ya han sido aprobadas pero que antes de ser sancionadas pueden ser sometidas a referéndum" ${ }^{101}$. Por lo que se refiere al referéndum abrogatorio, el diputado de UCD José Pedro Pérez-Llorca, al intervenir para apoyar la enmienda, afirmó que es una técnica que «plantea problemas similares, cuando no más delicados» que el referéndum legislativo de ratificación. En su opinión -expresando un temor que ya había puesto de relieve el diputado socialista Cordero en las Cortes Constituyentes de la Segunda República- el referéndum abrogatorio era nocivo para la estabilidad y el "armónico desarrollo» del sistema político, especialmente en el momento en que el Parlamento debía aprobar las leyes complementarias de la Constitución ${ }^{102}$. En turno en contra, intervino el profesor Fraga Iribarne para mostrar su total disconformidad con estas supresiones, pues a su juicio el referéndum es una ventana abierta a la participación de las fuerzas sociales en la vida política sin tener que pasar por el tamiz de los partidos políticos, evitando

proceso de elaboración de leyes ordinarias» (/bidem, p. 97). 3. ${ }^{a}$ Es opinión mayoritaria en la doctrina que con esta institución no se pretendia crear una vía directa de comunicación entre el Jefe del Estado y el pueblo, sino que, por el contrario, dicho «referéndum era un instrumento más del Gobierno para controlar la actividad legislativa de las Cortes, para que éstas se sintieran intimidadas ante la sola expectativa de su utilización y de este modo adecuaran su actuación a los dictados del Gobierno" (Ibidem, p. 96). 4." A nuestro juicio, lejos de ser un mecanismo democratizador del régimen, la Ley de Referéndum -publicada inmediatamente después de la derrota de las potencias fascistas en la Segunda Guerra Mundial- aparecía con la finalidad de legitimar ante la comunidad internacional un régimen politico fundamentado esencialmente en la fuerza de las armas.

${ }_{100}$ El artículo 85-1 del Anteproyecto de Constitución (BOC de 5 de enero de 1978) ofrecia la siguiente redacción: "La aprobación de las leyes votadas por las Cortes Generales y aún no sancionadas, las decisiones políticas de especial trascendencia y la derogación de leyes en vigor, podrán ser sometidas a referendum de todos los ciudadanos".

El Informe de la Ponencia de la Comisión de Asuntos Constitucionales del Congreso (BOC de 17 de abril de 1978), aceptando las enmiendas número 416 del Grupo Socialista y 529 del Grupo Mixto, modificó ligeramente el primer inciso del artículo 85-1 del Anteproyecto, aunque mantuvo sin variación las tres modalidades de referéndum: "Las leyes aprobadas por las Cortes y aún no sancionadas, las decisiones políticas de especial trascendencia y la derogación de las leyes en vigor, podrán ser sometidas a referéndum de todos los ciudadanos". ${ }_{101}$ Diario de Sesiones del Congreso de los Diputados (Comisión de Asuntos Constitucionales y Libertades Públicas), núm. 81, 6 de junio de 1978, p. 2937.

${ }_{102}$ lbidem, p. 2940. 
caer en la dañina "partitocracia» ${ }^{103}$. A esta última objeción, el profesor Solé Tura replicó diciendo que, en un país donde precisamente los partidos políticos han estado prohibidos durante cuarenta años, contemplar o denunciar el peligro de la partitocracia «es un mal servicio a la causa de la consolidación de la democracia que intentamos llevar adelante». Y añadió: "Aquí el problema que tenemos hoy no es el de la partitocracia, sino conseguir que los partidos funcionen, conseguir que los partidos sean representativos, que los partidos tengan fuerza, que los partidos sean reconocidos como intérpretes concretos de las grandes masas de la población, $y$ eso es lo fundamental»" ${ }^{104}$.

Sometida a votación, la enmienda fue aprobada por treinta y tres votos a favor $y$ dos en contra, sin abstenciones ${ }^{105}$. En consecuencia, el primer apartado del entonces artículo 86 quedaría —con redacción que ya iba a ser definitiva - con el siguiente tenor: «Las decisiones políticas de especial trascendencia podrán ser sometidas a referéndum consultivo de todos los ciudadanos» (BOC de 1 de julio de 1978). En el Pleno del Congreso de los Diputados se reprodujo el debate en términos muy similares, como consecuencia de la propuesta del profesor Fraga Iribarne de volver al texto de la Ponencia ${ }^{106}$. Por 243 votos contra 16 dicha pretensión fue rechazada.

${ }^{103}$ Ibidem, pp. 2939, 2941 y 2945. Define la «partitocracia» como aquel «momento en el cual los partidos no actúan como promotores de corrientes de opinión, de programas y de candidatos, sino como monopolizadores del proceso políticon.

104 Ibidem, p. 2942. Barrera Costa.

${ }^{105}$ Ibidem, p. 2945. Los dos votos en contra fueron de los diputados Fraga Iribarne y

${ }_{106}$ El profesor Manuel Fraga Iribarne solicitó con énfasis que se volvieran a consagrar las dos modalidades de referéndum suprimidas. De su interesante intervención entresacamos los siguientes fragmentos: “... entramos en una discrepancia absolutamente fundamental sobre cuáles son las relaciones entre el ciudadano y el Estado y cuál es su posibilidad, además de un medio normal, que es la democracia representativa, de actuar por vías de democracia semi-directa... nosotros no somos jacobinos ni rousseaunianos... no buscamos la democracia sin partidos; lo que queremos es completarla y compensarla... Se trata de que... de vez en cuando, haya una base para un rearme ciudadano, que es la base de la democracia y que además de los partidos haya una constante — ya lo dijo Tocqueville -, una gran constante plural de asociaciones voluntarias que... puedan promover sus causas paralelamente a esa síntesis y mediación que de ellas hacen los partidos... Creo... que sólo cuando hay un equilibrio... entre democracia representativa y democracia directa y semidirecta existe un sistema capaz de funcionar con realismon.

En turno de réplica, le contestó el diputado José Pedro Pérez-Llorca: «... En el fondo estamos aquí ante un problema valorativo de si vale más la pena que asentemos con nitidez el sistema parlamentario en toda su pureza, en nuestra Constitución, o lo podamos hacer convivir en ella con otros sistemas cuya eficacia en un sistema parlamentario no está bien probada... si con carácter constitucional adjuntáramos al sistema parlamentario unos instrumentos de democracia directa o semidirecta, estaríamos haciendo un régimen híbrido... estariamos haciendo un régimen extraordinariamente frágil. Es evidente que si constitucionalizamos los supuestos que plantea el señor Fraga... todos ellos podrían producir conflictos graves; conflictos graves entre las Cámaras y el pueblo, conflictos graves entre las Cámaras y el Gobierno. Y hay que evitar estos conflictos; hay que dejar que el sistema parlamentario 


\section{2) Restricción de los sujetos legitimados para solicitar la celebración de un} referéndum

En los tres primeros textos del iter constituyente, la legitimación para pedir la convocatoria de alguno de los tres tipos de referéndums facultativos reconocidos en el entonces artículo 85 (esto es, el legislativo de ratificación, sobre decisiones políticas de especial trascendencia y el legislativo abrogatorio) estaba atribuida a una pluralidad de sujetos. Así, en el Borrador de Constitución divulgado por la prensa en noviembre de 1977 se otorgaba -en todas las modalidades- al Gobierno, al Congreso, al Senado, a tres Asambleas regionales y a 500.000 electores ${ }^{107}$. En el Anteproyecto de Constitución, publicado en el $B O C$ el 5 de enero de 1978, se conferia dicha iniciativa al Congreso, al Senado y a tres Asambleas de Territorios Autónomos en las tres clases de referéndums, y a 750.000 electores en el supuesto del referéndum legislativo abrogatorio. La Ponencia en su Informe (BOC de 17 de abril de 1978), tras reestructurar el precepto con la oposición de UCD, legitimaba, en todos los supuestos, al Gobierno, al Congreso y al Senado, $y$, para convocar referéndums abrogatorios, a tres Comunidades Autónomas y a los electores en número no inferior a 750.000 .

Aunque en estas primeras fases del proceso constituyente ya se apreciaba una tendencia progresivamente restrictiva en el tema de la iniciativa de los referéndums, especialmente si eran legislativos derogatorios, y aunque también es innegable que algunas de las enmiendas formuladas al artículo 85 acentuaban notablemente esta impresión ${ }^{108}$, lo cierto es que "ninguna de ellas hacía presentir la drástica cirugía» a la que dicho artículo sería sometido en la Comisión de Asuntos Constitucionales del Congreso ${ }^{109}$. En efecto, al ser aprobada la enmienda in voce presentada en este trámite por el profesor Solé Tura, que ya hemos analizado parcialmente al estudiar la supresión de los dos tipos de referéndums legislativos, la facultad de solicitar la celebración de una consulta popular quedó restringida exclusivamente al Presidente del Gobierno ${ }^{110}$.

funcione, se enraice —cosa difícil- en el pueblo...". Diario de Sesiones del Congreso de los Diputados, núm. 109, 13 de julio de 1978, pp. 4210-4219.

${ }_{107} \mathrm{Cfr}$. «Las actas de la Ponencia Constitucional» publicadas en la Revista de las Cortes Generales, núm. 2, 1984, pp. 295 y 297.

108 La enmienda número 35 de D. Licinio de la Fuente (AP) proponía excluir de la legitimación para solicitar un referéndum a las Comunidades Autónomas. La enmienda 529 de D. Raúl Morodo (Grupo Parlamentario Mixto) excluía al Gobierno y a las Cámaras Legislativas, y la enmienda número 703 de D. Tomás Garcia (Grupo Parlamentario Comunista) a estas últimas, pero no al Ejecutivo. Desde otra perspectiva, la enmienda 736 de D. José Miguel Orti (UCD) elevaba a cinco el número de Asambleas regionales precisas para solicitar la celebración de un referéndum y exigía un determinado quórum de participación. En esta misma línea restrictiva, la enmienda número 779 del Grupo Parlamentario de Unión de Centro Democrático pretendía excluir la iniciativa popular y la de las Comunidades Autónomas.

109 Cfr. Pedro Cruz Villalón: «El referéndum...», op. cit., p. 151.

110 El segundo apartado del entonces artículo 86 , con redacción que aún iba a experimentar importantes alteraciones, rezaba así: «El referéndum será convocado por el Rey con refrendo del Presidente del Gobierno y previo debate del Congreso de los Diputados". 
Lo más Ilamativo -y posiblemente discutible- de este proceso restrictivo es la supresión de la iniciativa popular para exigir la celebración de un referéndum. Los argumentos de Heribert Barrera en el Pleno del Congreso de los Diputados oponiéndose a esta exclusión nos parecen especialmente sólidos. A su juicio, el que un determinado número de ciudadanos pudiera pedir la convocatoria de un referéndum evitaría «un posible divorcio entre la clase política y el país». Y añadía: «los partidos son sin duda instrumentos indispensables de la democracia, pero la oligarquía de los partidos o de los estados mayores de los partidos... me parece no solamente injusta, sino peligrosa para el futuro de la democracia, sobre todo si esto va acompañado de sistemas electorales que eliminan también, en gran parte, el contacto directo» con los representantes ${ }^{111}$. José Pedro Pérez-Llorca, con argumentos mucho más pragmáticos, justificaba la supresión de la iniciativa popular para demandar un referéndum afirmando que esta facultad otorgaría a los grupos minoritarios, e incluso extraparlamentarios, un poder extraordinario que podria «crear conflictos graves al funcionamiento adecuado del sistema» ${ }^{112}$.

\section{3) Calificación de "consultivo" al referéndum sobre decisiones políticas de es- pecial trascendencia}

La tantas veces citada enmienda in voce del profesor Solé Tura, además de suprimir las dos modalidades de referéndum legislativo y de restringir al Presidente del Gobierno la facultad de solicitar su convocatoria, calificó de "consultivo» al referéndum sobre "decisiones políticas de especial trascendencia». No vamos a analizar ahora el significado y el alcance jurídico-político de la agregación de este adjetivo, tema que trataremos con detalle al estudiar precisamente el referéndum consagrado en el artículo $92{ }^{113}$. Lo que sí debemos destacar en este momento es que el propósito de los constituyentes al introducirlo fue, sin ninguna duda, el de recortar la eficacia decisoria de este mecanismo de participación directa ${ }^{114}$.

De cuanto antecede se deduce claramente que bajo esta polémica, que aquí no hemos hecho más que apuntar, subyacía el problema de determinar en qué medida los mecanismos de participación directa debían «sobresalir en el juego político o ser meros correctores de la democracia

111 Diario de Sesiones del Congreso de los Diputados (Sesión Plenaria), núm. 109, 13 de julio de 1978, p. 4215.

112 lbidem, p. 4213.

${ }^{113}$ Cfr. infra 1.3.4.: «Alcance y significado del término consultivo aplicado a esta modalidad de referéndum".

${ }^{114}$ Cfr. las intervenciones de D. Jordi Solé Tura (DSCD, núm. 81, 6 de junio de 1978, pp. 2937, 2938 y 2942) y de D. José Pedro Perez-Llorca (DSCD, núm. 81, 6 de junio de 1978, p. 2940; y $D S C D$, núm. 109, 13 de julio de 1978, p. 4213). 
representativa” ${ }^{115}$. Este giro radical que experimentó la institución del referéndum en la Comisión de Asuntos Constitucionales del Congreso - similar al que habia experimentado en el mismo trámite la regulación de la iniciativa popular - responde, como afirma certeramente el profesor Santamaría Pastor, «a la asunción decidida de una opción política nítida, consistente en el reforzamiento de los mecanismos de la democracia representativa. Frente a una primera postura, un tanto ingenua, de democratización a ultranza, los constituyentes apreciaron con toda claridad los peligros de un posible abuso de la apellatio ad populum" ${ }^{116}$. Las causas principales de este giro espectacular, apoyado por todos los partidos políticos a excepción de Alianza Popular, fueron básicamente cuatro ${ }^{117}$ :

1. El recuerdo ínmediato de las connotaciones autoritarias y antipartidistas del referéndum en el régimen franquista. Fue precisamente el profesor Solé Tura quien, en el Pleno del Congreso, recordó que las consultas populares durante la autocracia del general Franco, lejos de ser un instrumento de participación directa, fueron montajes propagandísticos encaminados a legitimar un sistema político en el que el pueblo no tenia ningún poder efectivo ${ }^{118}$.

2. La polémica experiencia italiana del referéndum abrogatorio. EI hecho de que la práctica totalidad de las fuerzas políticas presentes en el proceso constituyente valorasen negativamente la experiencia italiana en el tema del referéndum abrogatorio ${ }^{119}$, pesó decisivamente en su supresión. Los parlamentarios españoles estimaban que el referéndum abrogatorio italiano había "generado no pocos problemas y (había) enturbiado un tanto el ambiente político, facilitando un campo de juego idóneo a los partidos políticos marginales y extraparlamentarios, y permitiendo saçar de los muros de los edificios que albergan. las Cámaras las contiendas políticas, para llevarlas a la calle" a través de la recogida de firmas y subsiguiente referéndum ${ }^{120}$. Además, estos recelos hacia el modelo italiano se vieron acentuados, en la Comisión del Congreso, por las peculiares características de la campaña que precedió a los dos referéndums que se celebraron en este país el 11 de junio de 1978 , cuyo objeto era pronunciarse

115 Cfr. Oscar Alzaga Villaamil: La Constitución..., op. cit., p. 585, 115.

116 Cfr. Juan Alfonso Santamaria Pastor: «Articulo 92», op. cit., p. 1315

117 Ibidem.

119 Diario de Sesiones del Congreso de los Diputados (Sesión Plenaria), núm. 109, 13 de julio de 1978, p. 4218.

119 Manuel Fraga Iribarne (DSCD, núm. 109, 13 de julio de 1978, p. 4212) y Heribert Barrera Costa (DSCD, núm. 109, 13 de julio de 1978, pp. 4216-17), en su pretensión de mantener el referéndum derogatorio en el Texto Constitucional, valoraron positivamente la experiencia italiana del 11 de junio de 1978.

${ }_{120}$ Cfr. Oscar Alzaga Villaamil: La Constitución..., op. cit., p. 581. 
sobre la Ley de medidas de orden público y sobre la Ley de financiación de los partidos políticos ${ }^{121}$.

\section{3..$^{a} \quad$ La repetida utilización del referéndum en la $\mathbf{V}$ República fran-} cesa con fines carismáticos. Parece evidente que la convocatoria de cinco referéndums en once años (1958-1969), buscando fortalecer la figura de su primer Presidente, también se dejó sentir negativamente en el ánimo de los legisladores españoles ${ }^{122}$.

4. $\quad$ La imperiosa necesidad de fortalecer y potenciar los partidos políticos en España tras cuatro décadas de estar prohibidos. Una vez más fue el profesor Solé Tura quien hizo oír su voz en el Parlamento. En esta ocasión, respondiendo a las críticas del profesor Fraga Iribarne en el sentido de que la supresión del referéndum era un «camino de servidumbre hacia la partitocracia", afirmó que fomentar el fortalecimiento de los partidos políticos nunca puede ser conceptuado de servidumbre, pues no es otra cosa que desarrollar el contenido del artículo 6 de la propia Constitución. Tras reconocer implícitamente que esta restricción del referéndum favorecía, en alguna medida, el protagonismo de los partidos políticos, agregó: "Queremos que los partidos se fortalezcan, que los partidos se desarrollen, que los partidos sean cada vez más representativos, más auténticamente representantes de lo que son las diversas formas de voluntad popular» ${ }^{123}$.

Los redactores de la Constitución española, muy influidos por los cuatro temas que acabamos de indicar, regularon el referéndum con un espíritu marcadamente restrictivo, lo que ha conducido a "descafeinar» en buena medida dicha institución ${ }^{124}$. Es indiscutible que en los primeros textos del iter constituyente las diversas modalidades de referéndum aparecían reguladas de "forma torpe e inconveniente», siendo susceptibles de engendrar problemas muy graves para el correcto funcionamiento del sistema ${ }^{125}$. Pero los constituyentes, en lugar de intentar evitar los riesgos mejorando su regulación, optaron por suprimir los dos tipos de referén-

121 Cfr. Pedro Cruz Villalón: “El referéndum...", op. cit., pp. 151-52; A. Manzella: «IJ sistema parlamentare nel proietto costituzionale spagnolo», en Politica del Diritto, IX, 3, 1978, p. 330 .

122 Cfr. Antonio Torres del Moral: Principios..., op. cit., p. 72.

${ }_{123}$ Diario de Sesiones del Congreso de los Diputados (Sesión Plenaria), núm. 109, 13 de julio de 1978, p. 4218. En la Comisión de Asuntos Constitucionales del Congreso (DSCD, núm. 81, 6 de junio de 1978, p. 2942), el profesor Jordi Solé Tura ya se habia pronunciado en términos muy similares.

${ }_{124}$ El profesor Óscar Alzaga VILlaAmIl (La Constitución..., op. cit., p. 587) utiliza esta expresión refiriéndose al referéndum consultivo previsto en el artículo 92.

${ }_{125}$ Cfr. Antonio Torres del Moral: Principios..., op. cit., pp. 109-110; Enrique Linde PANIAGUA y Miguel HeRrero LeRA: “El referéndum en la Constitución...», op. cit., p. 19. 
dums que más poder conferian a los ciudadanos y por restringir muy sensiblemente el referéndum sobre decisiones políticas. Como ha afirmado el profesor TOMÁS VILLARROYA, "si en otros tiempos o lugares se usó indebidamente del referéndum legislativo, lo pertinente no es suprimirlo, sino depurarlo y rescatarlo para la democracia. Pero, además - sigue diciendo el profesor de Valencia-, la democracia representativa, entre nosotros -y en otros lugares - aparece, en buena medida, expropiada por los partidos politicos: justo es que, en determinadas ocasiones, se conceda al pueblo la posibilidad de expresar directamente su voluntad» ${ }^{126}$.

\subsubsection{Normativa reguladora de la institución del referéndum}

Los aspectos esenciales de la institución del referéndum están recogidos en la propia Constitución y en la Ley Orgánica 2/1980, de 18 de enero, sobre regulación de las distintas modalidades de referéndum ( $B O E$ $23-1-1980)^{127}$. Junto a estos dos textos básicos, otras disposiciones como la Ley Orgánica 5/1985, de 19 de junio, del régimen electoral general (BOE $20-\mathrm{VI}-1985)$, la Ley $7 / 1985$, de 2 de abril, reguladora de las bases del régimen local (BOE 3-IV-1985) y el capítulo II del título VII del Reglamento del Congreso de los Diputados, de 10 de febrero de 1982 (BOE 5-III-1982), completan la regulación jurídica de las consultas populares directas en nuestro sistema constitucional. Por otra parte, y a los efectos de reglamentar los temas materiales y organizativos que se planteen en cada consulta referendaria, la disposición final segunda de la Ley Orgánica del referéndum autoriza al Gobierno para dictar las normas «que sean precisas para el cumplimiento y la ejecución” de dicha Ley.

a) Dispersos en diferentes títulos del Texto Constitucional, encontramos numerosos artículos que se refieren al referéndum. Los más importantes son los siguientes: artículo 62-c, facultad regia para convocarlos; artículo 92-1 y 2, referéndum consultivo; artículo 92-3, remisión a una ley orgánica de desarrollo; artículo 149-1-32. ${ }^{a}$, competencia del Estado para su autorización; artículo 151-1, referéndum de iniciativa autonómica; artículo 151-2, referéndum para aprobar estatutos de autonomia; artículo 152-2, referéndum para modificar estatutos de autonomía; artículo 167-3, referéndum de reforma constitucional facultativo; artículo 168-3, referéndum de reforma constitucional obligatorio; y disposición transitoria 4 . $^{a}$ punto 1 , referéndum para la incorporación de Navarra a la Comunidad Autónoma Vasca. Es evidente que algunos de estos preceptos, «a pesar de estar incluidos en el

126 Cfr. Joaquín TOMÁs VILLARROYa: "Comentario al libro El régimen constitucional español 1", en Revista Española de Derecho Constitucional, núm. 3, 1981, p. 346.

127 Su artículo 8-4, como veremos, fue modificado por la Ley Orgánica 12/1980, de 16 de diciembre (BOE 24-XII-1980). 
texto articulado", son normas de Derecho transitorio, que ya "han agotado su eficacia jurídica» al haberse consumado el «proceso de construcción del Estado autonómico» ${ }^{128}$.

b) El tercer párrafo del artículo 92 de la Constitución afirma que «una ley orgánica regulará las condiciones y el procedimiento de las distintas modalidades de referéndum previstas en esta Constitución». El hecho de que el párrafo transcrito forme parte del artículo dedicado al referéndum consultivo, suscitaba la duda de si dicha ley debía referirse exclusivamente al referéndum consultivo y sus posibles variantes o si, por el contrario, debía regular los tres tipos de referéndums previstos en la Constitución (esto es, el constitucional, el consultivo y el autonómico). Esta duda fue, sin embargo, rápidamente aclarada, pues el contenido de la Ley Orgánica reguladora del referéndum, de 18 de enero de 1980, afecta indubitadamente a aquellas tres modalidades ${ }^{129}$. Por el contrario, su disposición adicional precisa que "las disposiciones de la presente Ley no alcanzan en su regulación a las consultas populares que puedan celebrarse por los Ayuntamientos, relativas a asuntos relevantes de índole municipal, en sus respectivos territorios». En resumen, pues, el contenido de la L.O. 2/1980 es aplicable a los referéndums constitucionales, consultivos y autonómicos, pero no a los municipales.

Como es sabido, el iter parlamentario seguido por el Proyecto de Ley Orgánica sobre regulación de las distintas modalidades de referéndum estuvo estrechamente ligado al proceso autonómico andaluz ${ }^{130}$. En efecto, para poder entender el porqué de aquel precipitado e irregular procedimiento legislativo, a medio camino entre "la razón de Estado y la disciplina de partido" ${ }^{131}$, no hay que olvidar el compromiso político adquirido por el Presidente Suárez de celebrar el referéndum de iniciativa autonómica para Andalucía el 28 de febrero de 1980. Se produjo entonces, como han afirmado los profesores LINDE PANIAGUA y HERRERO LERA, «una falta de sincronia entre los compromisos personales adquiridos por el Presidente del Gobierno y las previsiones legales en que se debía enmarcar el cumplimiento

128 Cfr. Antonio Torres del Moral: Principios..., op. cit., p. 110.

129 Antes de aprobarse la L.O. 2/1980, esta solución ya habia sido defendida por diversos autores: Enrique LINDE PANIAGUa y Miguel HeRRERo LeRA: «EI referéndum en la Constitución...», op. cit., p. 30; Oscar AlzAGa VILLAAMIL: La Constitución..., op. cit., p. 587.

130 Cfr., entre otros, Joaquín TomÁs VILLARROYA: «Proceso autonómico y observancia de la Constitución», en Revista Española de Derecho Constitucional, núm. 15, 1985, p. 39; Luis ORTEGa ÁlvarEZ: «La inconstitucionalidad de la reforma de la Ley Orgánica de Referéndum» en Revista de Administración Pública, núm. 97, 1982, p. 175; Enrique Linde Paniagua y Miguel Herrero Lera: "Comentario a la Ley Orgánica de modalidades de referéndum», en Revista del Departamento de Derecho Político, núm. 6, primavera 1980, pp. 85-86; María Rosa RIPOLLÉs SERRANO: “Notas...”, op. cit., pp. 329,330 y 339.

${ }_{131}$ Cfr. Maria Rosa Ripollés Serrano: “Notas...», op. cit., p. 330. 
de aquéllos» ${ }^{132}$, pues esta consulta popular sólo se podía celebrar si previamente había sido aprobada la Ley Orgánica reguladora del referéndum. Ante esta comprometida situación, el Gobierno de UCD remitió al Parlamento el Proyecto de Ley a mediados de noviembre de $1979{ }^{133}$, solicitando que fuera tramitado por el procedimiento legislativo de urgencia. Tras el Informe de la Ponencia, la Comisión de Asuntos Constitucionales del Congreso lo dictaminó en dos sesiones, siendo aprobado por el Pleno -en versión que ya iba a ser definitiva- el 28 de diciembre ${ }^{134}$. En la sesión extraordinaria del 15 de enero de 1980, la Cámara Alta, a los efectos de que el Proyecto no tuviera que volver al Congreso, lo aprobó sin ninguna alteración, aunque para ello fue preciso que los senadores centristas y socialistas retiraran - bajo la presión de sus propios partidos- las enmiendas que habian presentado. No es de extrañar, pues, que, en este contexto, el parlamentario de UCD Antonio Pérez Crespo dijera que como senador «sentía un amargo sabor» por la marginación de que había sido objeto el Senado ${ }^{135}$. A tenor de todo lo anterior, es evidente que la temprana aprobación de la Ley Orgánica del referéndum no se debió al deseo del legislador de articular rápidamente cauces de participación directa, sino a la necesidad de contar con la normativa precisa para poder convocar el referéndum andaluz de iniciativa autonómica (art. 151-1) ${ }^{136}$.

Las consecuencias de esta precipitada aprobación de la Ley Orgánica del referéndum son principalmente tres. En primer lugar, el contenido de esta Norma es claramente desproporcionado, pues en tanto que los referéndums autonómicos previstos en el artículo 151 de la Constitución son reglamentados de forma exhaustiva, los referéndums constitucional y consultivo son objeto de una regulación breve $y$, en muchos aspectos, insuficiente ${ }^{137}$. En segundo lugar, también debemos destacar que se trata de una ley notablemente restrictiva, que desconoce en buena medida «las posibilidades y virtualidades democratizadoras" del referéndum ${ }^{138}$. Finalmente, en tercer lugar, hay que señalar que es una ley técnicamente muy deficiente, hasta el extremo que el profesor TORRES DEL MORAL afirma que sus «errores y defectos técnicos casi se cuentan por palabras» ${ }^{139}$.

132 Cfr. Enrique Linde Paniagua y Miguel Herrero Lera: “Comentario a la Ley...», op. cit., p. 85.

${ }^{133}$ El Proyecto remitido por el Gobierno fue publicado en el Boletín Oficial de las Cortes, núm. 97-I, serie A, de 23 de noviembre de 1979.

${ }_{134}$ Diario de Sesiones del Congreso de los Diputados (Sesión Plenaria), núm. 59, 28 de diciembre de 1979. La votación arrojó el siguiente resultado: 258 votos a favor, 17 en contra y tres abstenciones.

${ }_{135}$ Diario de Sesiones del Senado (Sesión Plenaria), núm. 38, 15 de enero de 1980.

136 Con criterio análogo, cfr. Luis AGUIAR DE LuQUE: «La Ley Orgánica...», op. cit., p. 168.

137 Cfr. Enrique Linde Paniagua y Miguel Herrero Lera: “Comentario a la Ley...", op. cit., pp. 87 y 89 .

${ }^{138}$ Cfr. Luis Aguiar de LuQUe: «Referéndum», op. cit., p. 793; Idem: “La Ley Orgánica...”, op. cit., pp. 170-71.

${ }_{139}$ Cfr. Antonio Torres del Moral: Principios..., op. cit., p. 109. 
Si el proceso de elaboración de la Ley Orgánica del referéndum fue, como hemos visto, anómalo y polémico, sin que faltaran reiteradas acusaciones de inconstitucionalidad, debemos añadir ahora que el debate no se cerró con la aprobación de dicha Ley. Por el contrario, a raíz del insuficiente resultado producido en la provincia de Almería el 28 de febrero de 1980, que impedía a Andalucía constituirse en Comunidad Autónoma por la vía del artículo 151, se modificó el párrafo cuarto del artículo octavo de la Ley Orgánica $2 / 1980$, de 18 de enero. Esta reforma - a la que se dio efectos retroactivos para poder considerar positivos los resultados negativos del referéndum andaluz - se formalizó en la Ley Orgánica 12/1980, de 16 de diciembre (BOE 24-XII-1980) ${ }^{140}$.

\subsection{Referéndums de reforma constitucional}

\subsubsection{Introducción}

«Desde sus mismos orígenes doctrinales, el referéndum ha sido considerado como instrumento adecuado para la ratificación de procesos de reforma constitucional» ${ }^{141}$. Fue el marqués de CONDORCET (1743-1794) quien, llevando hasta sus últimas consecuencias los planteamientos de Sieyès, elaboró la «primera formulación de los modernos referéndums constitucionales" ${ }^{142}$. En su opúsculo.publicado en 1789 bajo el título Sur la nécessité de faire ratifier la Constitution par les citoyens, Condorcet afirma que es preciso que la Constitución sea elaborada por unos representantes extraordinarios, como defiende el abate Sieyès, pero añade que ello no es suficiente, sino que es necesario además que el conjunto de ciudadanos la ratifique. «El pueblo -escribe Condorcet- no ha delegado más que la función de redactar la Constitución, función que él no puede ejercer; pero (en) el rechazo o la aceptación expresa su verdadero deseo" ${ }^{143}$.

Las influencias del pensamiento democrático de Condorcet son muy claras en el proceso revolucionario francés. Así, el Decreto de 21 de septiembre de 1972, buscando un fundamento legítimo al nuevo orden político, declaraba que «no puede haber Constitución que no haya sido aceptada por el pueblo". Este Decreto, como ha afirmado el profesor AGUIAR, constituye el primer «reconocimiento juridico» de «la participación popular directa en el poder constituyente» ${ }^{144}$. Sin embargo, la plasmación más com-

140 Cfr. infra 1.4.2.: «Referéndum para que una proyectada Comunidad Autónoma pueda acceder a la autonomia plena por la vía rápida sin reunir los requisitos que exige la disposición transitoria segunda (art. 151-1)".

${ }^{141}$ Cfr. Luis Aguiar de LUQUe: «Referéndum», op. cit., p. 793.

142 Cfr. Luis AgUIAR DE LuQUE: Democracia..., op. cit., p. 30.

${ }_{143}$ Cfr. Marqués de CONDORCET: Sur la nécessité de faire ratifier la Constitution par les citoyens, oeuvres completes, tomo XV, Paris 1804, capitulo II.

${ }^{144}$ Cfr. Luis Aguiar de Luque: Democracia..., op. cit., p. 42. 
pleta de las ideas de Condorcet la encontramos en el Proyecto de Constitución girondino de 1793, del que fue su principal artífice. En este texto se prevé la participación directa como mecanismo para aprobar y modificar la Constitución. En concreto, el artículo 10 del título IX afirmaba que la reforma constitucional sólo entraría en vigor cuando el nuevo texto hubiera sido aprobado por el pueblo ${ }^{145}$.

Un rápido repaso a las vicisitudes de la institución referendaria durante estos dos últimos siglos, demuestra que ha sido precisamente en el tema de la aprobación y reforma de las Constituciones donde ha sido aceptada con menos dificultad. Quizá, como afirma el profesor Julián SANTAMARÍA ${ }^{146}$, porque reconcilia «la noción democrática de la participación directa con la noción conservadora de la rigidez constitucional» ${ }^{147}$.

Desde la Constitución de Bayona de 1808 hasta la de la Segunda República de 1931, en ningún texto fundamental español se introdujo la necesidad de ratificación popular para modificario. En unos casos esta facultad de reforma se reconocia a las Cortes a través del procedimiento legislativo ordinario (vg. Constituciones de 1837 y 1876), en otros se establecian unos trámites agravados (vg. Constituciones de 1812 y 1869), pero en ninguna de ellas, repito, se preveía la consulta directa al pueblo. Fue durante el régimen del general Franco cuando, al objeto de ofrecer una imagen de legitimidad en el interior y ante la comunidad internacional, se incorporó la figura del referéndum constitucional. Asi, el artículo 10 de la Ley de Sucesión en la Jefatura del Estado de 1947 preveía el referéndum obligatorio para modificar o derogar las Leyes Fundamentales ${ }^{148}$. Esta técnica se utilizó en dos ocasiones: en julio de 1947 para aprobar la propia Ley de Sucesión (aunque esta consulta tenia su fundamento juridico en el artículo 1 de la Ley de Referéndum Nacional de 1945) y en diciembre de

145 Cfr. Luis Aguiar de LuQUe: Democracia ..., op. cit., p. 43

146 Cfr. Julián Santamarla OssoRIO: «Participación pölítica...», op. cit., p. 755.

${ }_{147}$ En el marco del Derecho comparado son numerosas las Constituciones que, con mayor o menor amplitud, incorporan el referéndum a su proceso de reforma. A título de ejemplo, cfr. artículo 88 de la Constitución danesa de 1953, artículo 89 de la Constitución francesa de 1958, artículos 46 y 47 de la Constitución irlandesa de 1937 y artículo 138 de la Constitución italiana de 1947.

${ }_{148}$ El artículo 10 de la Ley de Sucesión en la Jefatura del Estado de 26 de julio de 1947 decía así: «Para derogarias o modificarlas (a las Leyes Fundamentales) será necesario, además del acuerdo de las Cortes, el referéndum de la Nación». Por su parte, el artículo 7 de la Ley Orgánica del Estado de 10 de enero de 1967 establecía que acorresponde, particularmente, al Jefe del Estado: (...) c) Someter a referéndum de la Nación los proyectos de ley a que se refiere el párrafo segundo del artículo 10 de la Ley de Sucesión».

La convocatoria de estos referéndums, a diferencia de los previstos en la Ley de Referéndum de 1945, estaba configurada como un acto debido del Jefe del Estado, ya que dicha consulta -que debía recaer sobre un texto previamente aprobado por las Cortes - era un trámite preceptivo en el proceso de reforma de las Leyes Fundamentales. Cfr. Enrique LINDE Paniagua y Miguel Herrero Lera: «El referendum: de las Leyes...», op. cit., pp. 97-98. 
1966 para aprobar la Ley Orgánica del Estado ${ }^{149}$. Por otra parte, al comienzo de la transición democrática, la Ley para la Reforma Política de 1976 volvía a introducir esta técnica, al afirmar que «el Rey, antes de sancionar una ley de reforma constitucional», debía «someter el proyecto a referéndum de la nación» (art. 3-3).

La Constitución española de 1978 está dotada de una fuerte rigidez, pues su título décimo (arts. 166-169), al regular los procedimientos de reforma constitucional, yuxtapone una serie de trámites y requisitos que muy raramente se encuentran juntos en el Derecho comparado (SANTAOLALLA LÓPEZ). Se puede afirmar, sin duda, que la vigente es «la más rígida de todas las constituciones españolas» a excepción de la gaditana de $1812{ }^{150}$. Antes de seguir adelante, hemos de precisar que no vamos a entrar en el estudio de los diversos trámites que deben seguirse para modificar la Constitución, ya que, como es obvio, es un tema ajeno al objeto de nuestro análisis, circunscrito a la institución del referéndum.

En nuestra Carta Magna se regulan dos procedimientos de reforma constitucional: el ordinario (art. 167), para las modificaciones menos importantes, que puede concluir o no con un referéndum; y el extraordinario (art. 168), para las alteraciones esenciales o totales, que necesariamente deberá finalizar con una consulta popular. Como vemos, se han incluido en nuestro sistema político dos tipos de referéndums de reforma constitucional: uno facultativo y otro obligatorio. Aunque ambas modalidades pretenden «acentuar el carácter rígido de la Constitución» ${ }^{151}$, parecen responder a finalidades políticas distintas: «protección de las minorias en el referéndum previsto en el artículo 167, legitimación popular de la reforma en el supuesto contemplado por el artículo $168 »{ }^{152}$.

Los referéndums de reforma constitucional están consagrados, en sus aspectos esenciales, en los artículos 167-3 y 168-3 de la Ley Fundamental, y escuetamente reglamentados en el artículo 7 de la Ley Orgánica sobre regulación de las distintas modalidades de referéndum. Tal como ya hemos señalado, esta Ley, precipitadamente aprobada con el objeto de resolver el problema autonómico andaluz, muestra un preocupante desin-

149 El procedimiento para la celebración de estos dos referéndums se fijó por los Decretos de 8 de mayo de 1947 y 21 de noviembre de 1966.

150 Cfr. Antonio TORRES DEL MORAL: Principios de Derecho Constitucional español 2, Atomo Ediciones, Madrid 1986, p. 434.

151 Cfr. Pedro CRUz VILLALON: «El referéndum...», op. cit., p. 165.

152 Cfr. Luis AgUIAR DE LuQUE: «Referéndum», op. cit., p. 793. Desde una perspectiva teórica, el profesor Cruz Villalón ha destacado el «contrapuesto significado político» del referéndum obligatorio y del referéndum facultativo: «mientras el primero se limita a perfilar el peso decisorio directo del cuerpo electoral, el facultativo se configura muy predominantemente como una facultad trascendental que la Constitución pone en manos de un determinado órgano (incluida una fracción de aquél), la de provocar la manifestación de la voluntad inmediata del pueblo, la consulta popular, l'appel au peuple». Cfr. Pedro CRUz VILLALÓN: «EI referéndum...", op. cit., p. 146. 
terés por resolver las diversas cuestiones que suscitan los referéndums de reforma constitucional ${ }^{153}$.

\subsubsection{Modalidades del referéndum de reforma constitucional}

\subsubsection{Referéndum de reforma constitucional facultativo (art. 167)}

El artículo 167 de la Constitución establece lo que podriamos denominar el procedimiento de reforma constitucional ordinario, que debe seguirse cuando la modificación que se quiere introducir es parcial y no afecta al título preliminar, ni a la sección primera del capítulo II del título I, ni al título II. En estos casos, tras haber seguido los trámites procedimentales preceptuados ${ }^{154}$, la reforma aprobada por las Cortes podrá ser sometida a referéndum para su ratificación. Es preciso para ello que lo «soliciten, dentro de los quince días siguientes a su aprobación, una décima parte de los miembros de cualquiera de las Cámaras» (art. 167-3).

Según se desprende de lo anterior, aunque en principio la celebración del referéndum no es un requisito indispensable para consumar la reforma constitucional, sí que lo es cuando lo solicitan en el plazo indicado un 10 por 100 de los diputados o de los senadores. En cuyo caso, como es obvio, el texto reformado sólo entrará a formar parte del ordenamiento constitucional si obtiene el respaldo necesario del pueblo español. El porcentaje de parlamentarios exigido para provocar la convocatoria de este referéndum es, a nuestro juicio, moderadamente bajo, y lo convierte en un «trámite obligado» para cualquier reforma mínimamente controvertida ${ }^{155}$. Como afirma el profesor CRUZ VILLALÓN, «habrá de tratarse de enmiendas constitucionales eminentemente técnicas o cuidadosamente pactadas para que no surja en ninguna de las dos Cámaras una décima parte de sus miembros dispuestos a provocar el referéndum» ${ }^{156}$.

Un tema de particular interés es el de precisar si el Presidente del Gobierno puede disolver las Cortes antes de que hayan transcurrido los quince días dentro de los cuales los parlamentarios pueden solicitar la ce-

153 Cfr. Manuel RamíRez Jiménez: La participación..., op. cit., p. 139; Enrique Linde PaNIAGUA y Miguel HeRrero LeRA: «Comentario a la Ley...", op. cit., pp. 87-88.

${ }_{154}$ El procedimiento ordinario de reforma constitucional está establecido en los dos primeros apartados del artículo 167: «1. Los proyectos de reforma constitucional deberán ser aprobados por una mayoría de tres quintos de cada una de las Cámaras. Si no hubiera acuerdo entre ambas, se intentará obtenerlo mediante la creación de una Comisión de composición paritaria de diputados y senadores, que presentará un texto que será votado por el Congreso y el Senado. 2. De no lograrse la aprobación mediante el procedimiento del apartado anterior, y siempre que el texto hubiere obtenido el voto favorable de la mayoria absoluta del Senado, el Congreso por mayoría de dos tercios podrá aprobar la reforma».

155 Cfr. Luis AguiaR de LuQue: “Referéndum», op. cit., p. 794; Manuel RAmIREZ Jiménez: La participación..., op. cit., p. 128.

${ }^{156}$ Ctr. Pedro Cruz VILLALON: «El referéndum...», op. cit., p. 165. 
lebración del referéndum. Aunque algún autor ha defendido esta posibilidad ${ }^{157}$, a nuestro juicio debe rechazarse decididamente, pues tal práctica constituiría un auténtico fraude de ley. Como ha indicado el profesor TORRES DEL MORAL, no es «constitucionalmente admisible que la mayoría, por medio del Gobierno, cercene esta garantía que la Norma Suprema ofrece a las minorias" ${ }^{158}$.

El referéndum facultativo que prevé el artículo 167 es «defendible desde el prurito de hacer a la revisión lo más democrática posible». Sin embargo, como advierte el profesor DE ESTEBAN, «hay que tener en cuenta que sólo merecerá la pena de poner en marcha el costoso gasto de la consulta popular si la modificación que se propone es sustancialmente importante" ${ }^{159}$.

\subsubsection{Referéndum de reforma constitucional obligatorio (art. 168)}

El artículo 168 de la Ley Fundamental introduce un procedimiento de reforma constitucional extraordinariamente agravado ${ }^{160}$, que deberá seguirse en el caso de revisiones totales o parciales que afecten al título preliminar (arts. 1-9), a la sección primera del capítulo segundo del título primero (arts. 15-29) o al título segundo (arts. 56-65) ${ }^{161}$. Este procedimiento, que exige entre otros trámites la aprobación de la reforma por dos Parlamentos sucesivos ${ }^{162}$, concluye preceptivamente con un referéndum de ratificación (art. 168-3). Se trata, pues, de un referéndum de carácter obli-

157 El profesor Enrique Álvarez CONDE (El régimen político español, Tecnos, Madrid 1983 , p. 316) ha escrito: "... los partidos mayoritarios... pueden impedir el ejercicio de esta facultad disolviendo, por medio del Presidente del Gobierno, las Cortes nada más aprobada la reforma, con lo cual el referéndum ya no podría ser solicitadom.

158 Cfr. Antonio Torres del Moral: Principios..., op. cit., vol. II, pp. 436-37.

159 Cfr. Jorge de Esteban: El régimen..., op. cit., p. 96.

160 Según los profesores Jorge DE ESTEBAN (El régimen... op. cit., p. 96) y Antonio ToRRES del Moral (Principios..., op. cit., vol. II, p. 442) será muy difícil, sino imposible, que esta vía llegue a utilizarse.

${ }_{161}$ Estos tres bloques comprenden: los principios políticos fundamentales de nuestro sistema constitucional (título preliminar), los derechos fundamentales y las libertades públicas (sección 1." del capítulo II del título I) y la regulación de la Corona (título II).

Esta selección de materias es, según algunos autores, poco afortunada, pues incluye algunas de orden secundario (vg. las incompatibilidades del tutor del Rey o el reconocimiento de las banderas de las Comunidades Autónomas) y deja fuera, en cambio, otras de capital importancia (vg. el principio de igualdad o las garantías de los derechos fundamentales). Cfr., en este sentido, Antonio TORRES DEL MORAL: Principios..., op. cit., vol. II, p. 437; Enrique Álvarez CONDE: El régimen..., op. cit., p. 317.

${ }_{162}$ El Congreso y el Senado deberán aprobar el principio de revisión constitucional por mayoría de dos tercios de cada Cámara, produciéndose acto seguido la disolución inmediata de las Cortes. Las nuevas Cámaras elegidas deberán ratificar la decisión adoptada por las anteriores sobre el principio de revisión y «proceder al estudio del nuevo texto constitucional, que deberá ser aprobado por mayoria de dos tercios de ambas Cámaras'. Posteriormente, el texto así aprobado deberá ser sometido a referéndum para su ratificación. 
gatorio, que tiene lugar ope legis, por mandato constitucional, sin que sea preciso que algún órgano solicite su convocatoria.

Aunque resulta lógico y encomiable que «se involucre al cuerpo electoral» siempre que se quiera modificar algún aspecto fundamental de la Constitución ${ }^{163}$, creemos que el referéndum exigido en el último párrafo del artículo 168 ofrece algunas notas de incoherencia. En efecto, después de que las primeras Cortes hayan aprobado el principio de revisión constitucional serán inmediatamente disueltas y se convocarán nuevas elecciones, que «tendrán como punto central de la campaña la conveniencia o la inoportunidad de la revisión». "Si ésta resulta nuevamente aprobada por el Parlamento es porque los electores han dado su visto bueno a la iniciativa de reforma constitucional, otorgando su voto a los partidos que la defienden; de esta manera la exigencia adicional de un referéndum posterior fijada en el artículo 168 resulta superflua, y se convierte exclusivamente en un obstáculo más para desalentar el proceso revisionista" ${ }^{164}$.

\subsubsection{Algunas cuestiones procedimentales en torno a los referéndums de reforma constitucional}

De acuerdo con el artículo 7 de la Ley Orgánica reguladora de las distintas modalidades de referéndum, "en los casos de referéndum constitucional previstos en los artículos 167 y 168 de la Constitución, será condición previa la comunicación por las Cortes Generales al Presidente del Gobierno del proyecto de reforma aprobado que haya de ser objeto de ratificación popular». «Recibida la comunicación se procederá, en todo caso, a la convocatoria dentro del plazo de treinta días y a su celebración dentro de los sesenta días siguientes». Añadamos que si se tratara de un referéndum facultativo, la referida comunicación debería ir acompañada de la preceptiva solicitud del 10 por 100 de los diputados o de los senadores.

Al hilo de este precepto, podemos plantearnos dos cuestiones: primera, ¿quién es el responsable de la convocatoria de estos referéndums?; y segunda, ¿puede subsanar el resultado afirmativo del referéndum los eventuales errores procedimentales que se hayan podido producir?

a) El primer tema, esto es el de precisar quién es el responsable de la convocatoria de los referéndums de reforma constitucional, se plantea a partir de la consideración de que el Presidente del Gobierno, una vez que ha recibido la comunicación de las Cortes, está obligado a refrendar la convocatoria del referéndum en los plazos indicados, sin que pueda entrar

163 Cfr. Jorge DE EsTEBAN: El régimen..., op. cit., p. 96.

164 Cfr. Joaquín TOMÁs VILLARROYA: "Comentario...», op. cit., pp. 342-43. Con criterio análogo puede verse Enrique Álvarez Conde: El régimen..., op. cit., p. 319. 
a fiscalizar la corrección o incorrección del procedimiento seguido hasta entonces. Con lo cual resulta que el Jefe del Ejecutivo, al refrendar el acto regio de convocatoria, asume automáticamente la responsabilidad del mismo, sin que haya podido practicar ni tan siquiera el control de legalidad. A juicio de los profesores LINDE PANIAGUA y HERRERO LERA, esta incoherencia se habria podido evitar si el artículo 64-1 de la Constitución, al determinar los casos en que el refrendo debe proceder del Presidente del Congreso, hubiera incluido la convocatoria de estos referéndums ${ }^{165}$.

b) Otro tema de indudable interés es el de determinar si un referéndum con resultado positivo puede subsanar los eventuales errores cometidos en el procedimiento parlamentario que ha conducido al texto de reforma constitucional finalmente sometido a ratificación popular. A juicio del profesor TORRES DEL MORAL, si el referéndum obtiene resultado positivo, "los defectos formales habidos con anterioridad quedan subsanados con la posterior intervención del pueblo" siempre que se den tres condiciones: 1. ${ }^{a}$ que la voluntad popular se haya expresado a través de sufragio universal, libre, directo y secreto; $2 .^{a}$ que el resultado afirmativo del referéndum conste de forma fehaciente; y $3 .^{a}$ que el defecto formal «no haya sido determinante del resultado". Defiende esta solución invocando el principio de conservación de los actos políticos y los amplios términos con que el artículo 1-2 de la Constitución consagra la titularidad popular de la soberania ${ }^{166}$.

\subsection{Referéndum consultivo (art. 92)}

\subsubsection{Introducción}

La modalidad más novedosa y a su vez problemática de la institución referendaria ${ }^{167}$ la consagra la Constitución en su artículo 92-1, al afirmar que «las decisiones politicas de especial trascendencia podrán ser sometidas a referéndum consultivo de todos los ciudadanos». Añadiendo, el segundo apartado de este mismo precepto, que «el referéndum será convocado por el Rey, mediante propuesta del Presidente del Gobierno, previamente autorizado por el Congreso de los Diputados». El referéndum consultivo es, a nuestro juicio, una "figura interesante», tanto por sí misma como, sobre todo, por lo que significa de nuevo intento de incorporar a una

165 Cfr. Enrique Linde Paniagua y Miguel Herrero Lera: “Comentario a la Ley...», op. cit., pp. 95-97.

166 Cfr. Antonio Torres del Moral: Principios..., op. cit., vol. Il, pp. 444-45.

167 Cfr. Luis Aguiar de LuQue: «Referéndum», op. cit., p. 794. 
Constitución eminentemente representativa algunas fórmulas de democracia directa ${ }^{168}$.

Aunque esta modalidad referendaria aparece escasamente constitucionalizada en el Derecho comparado, debemos referirnos como un claro precedente al modelo sueco ${ }^{169}$. Parece evidente que «el referéndum consultivo español responde al planteamiento de la Constitución de Suecia, es decir, se ha optado por incorporar a la Constitución la figura de la consulta popular, pero sin que ésta interfiera en el carácter representativo de nuestra democracia ni, sobre todo, en el funcionamiento del régimen parlamentario que se pretende implantar» ${ }^{\text {t70. }}$

El artículo 92 de la Constitución, fruto de un laborioso proceso parlamentario que se prolongó hasta la Comisión Mixta Congreso-Senado y que - como hemos visto- restringió muy sensiblemente el alcance de la institución referendaria ${ }^{171}$, es un precepto ambiguo que, desafortunadamente, apenas ha sido desarrollado por la Ley Orgánica reguladora de las distintas modalidades de referéndum. En efecto, el artículo 6 de dicha Ley, único que se refiere a esta clase de referéndum, se limita a precisar que la solicitud del Presidente del Gobierno al Congreso de los Diputados "deberá contener los términos exactos en que haya de formularse la consulta", y que la autorización de la Cámara Baja deberá ser por mayoría absoluta ${ }^{172}$. Aspectos tan importantes como el objeto de la consulta, los efectos vinculantes o no vinculantes del resultado, la precisión de lo que debe entenderse por «decisión política de especial trascendencia» o la posibilidad de celebrar referéndums consultivos de ámbito infraestatal, son algunos de los numerosos temas que pasaron totalmente desapercibidos para los le-

168 Valoración análoga puede verse en el trabajo del profesor Pedro CRUz VILLALÓN: «El referéndum...», op. cit., p. 145.

${ }_{169}$ El actual artículo 4 del capítulo VIII de la Constitución sueca se limita a decir que «la ley establecerá las disposiciones imperativas por las que se regirán los referéndums consultivos organizados en el conjunto del pais». Más explícito era el apartado segundo añadido en 1922 al entonces artículo 49: «En el caso de que la importancia y la naturaleza pairticular de una cuestión exija que la opinión del pueblo sea recabada antes de la decisión definitiva del asunto, el Rey y el Riksdag podrán, por medio de una ley hecha en común, decretar un referéndum general. Esta ley deberá precisar la cuestión o cuestiones a que responderá el referéndum, e indicar el tiempo y la manera del referendum. Tiene derecho a participar en el referéndum cualquiera que tenga derecho a votar para la Segunda Cámara. Cerrado el referéndum, la cuestión será tratada conforme a las leyes fundamentales».

170 Cfr. Pedro CRUz VILLALÓN: «El referéndum...», op. cit., p. 159.

171 Los aspectos más llamativos de esta desconfiada y restrictiva trayectoria constitucional son tres: la supresión del referéndum legislativo de ratificación y del referéndum legislativo abrogatorio, la restricción de los sujetos legitimados para solicitar la celebración de un referéndum, y la calificación de "consultivo" al referéndum sobre decisiones políticas de especial trascendencia. Cfr. supra 1.1.1.: «El referéndum en el proceso constituyente».

${ }_{172}$ El artículo 6 de la Ley Orgánica $2 / 1980$, de 18 de enero, ofrece la siguiente redacción: «El referéndum consultivo previsto en el artículo 92 de la Constitución requerirá la previa autorización del Congreso de los Diputados por mayoría absoluta, a solicitud del Presidente del Gobierno. Dicha solicitud deberá contener los términos exactos en que haya de formularse la consultam. 
gisladores, únicamente preocupados por dar una rápida solución al problema autonómico andaluz.

Aunque no es previsible un uso frecuente de esta modalidad de referéndum, debemos recordar que recientemente ha sido utilizada en un tema extraordinariamente polémico: la decisión política del Gobierno en relación con la Alianza Atlántica ${ }^{173}$. La apasionada campaña electoral que precedió a dicha consulta, unida a lo incierto del resultado hasta el último momento ${ }^{174}$, motivó numerosos artículos y comentarios. En ellos, al tiempo que se ponían de relieve las ambigüedades y los problemas inherentes al referéndum consultivo, se proponian diversas soluciones que, sin duda, nos servirán para perfilar mejor los contornos jurídicos de esta figura.

\subsubsection{Procedimiento que debe seguirse para convocar un referéndum consultivo}

Lo primero que hay que indicar es que el referéndum previsto en el artículo 92 de la Constitución tiene carácter facultativo ${ }^{175}$, lo que significa que los poderes públicos pertinentes podrían adoptar la decisión política de especial trascendencia sin consultar previamente al pueblo. Dicho con otras palabras, se consulta al cuerpo electoral porque se quiere, no porque

173 En el Boletin Oficial del Estado de 7 de febrero de 1986 se publicó el Real Decreto 214/1986, de 6 de febrero, por el que se somete a referéndum de la Nación la decisión politica del Gobierno en relación con la Alianza Atlántica. Para la celebración de este referéndum se dictaron numerosas normas complementarias, las más importantes son las siguientes: Real Decreto 215/1986, de 6 de febrero; Real Decreto 216/1986, de 6 de febrero; Real Decreto 217/ 1986, de 6 de febrero; Real Decreto 218/1986, de 6 de febrero; y Real Decreto 440/1986, de 28 de febrero. Para un estudio de esta consulta puede verse el trabajo del EQUIPO DE SOCIOLOGIA ELECTORAL DE LA UNIVERSITAT AUTONOMA DE BARCELONA titulado: «EI referéndum del 12 de marzo de 1986 sobre la permanencia de España en la OTAN y sus consecuencias para el sistema politico", en Revista de Estudios Politicos, núm. 52, 1986, pp. 183-215.

174 Los resultados que se produjeron el 12 de marzo de 1986 fueron mucho más progubernamentales de lo que era previsible a tenor de las encuestas electorales. En concreto, fueron los siguientes ( $B O E$ de 2 de abril de 1986 y $B O E$ de 11 de abril de 1986):

Electores: 29.024 .494

Votantes: 17.246 .880

Votos afirmativos: 9.054 .509

Votos negativos: 6.872 .421

Votos en blanco: 1.127 .673

Votos nulos: 191.849

175 Cfr. Jorge de Esteban: El régimen..., op. cit., p. 96; Pedro Cruz Villalón: «El referéndum...", op. cit., pp. 149 y 160; Enrique LINDE PANIAGUA y Miguel HERRERO LERA: «El referéndum en la Constitución...", op. cit., p. 37; Enrique Linde PANIAGUA: «Artículo 92...", op. cit., p. 395 . 
haya una obligación jurídica de hacerlo. Sentada esta precisión, debemos señalar que el proceso que conduce a la celebración de un referéndum consultivo se compone básicamente de tres fases: $1 .^{a}$ propuesta del Presidente del Gobierno; $2 .^{a}$ autorización del Congreso de los Diputados; y 3 . $^{\mathrm{a}}$ convocatoria formal del Rey. Analicémoslas por separado.

\section{1. $\quad$ Propuesta del Presidente del Gobierno}

Parece evidente que la iniciativa en este tipo de referéndums corresponde de forma exclusiva al Presidente del Gobierno, quien libremente decidirá si pone en marcha o no el procedimiento que, en su caso, conducirá a la celebración de la consulta. Se trata, como vemos, de un aacto personalísimo" que no precisa siquiera del acuerdo previo del Consejo de Ministros ${ }^{176}$, lo que sin duda contribuirá a fortalecer la figura de su Presidente ${ }^{177}$. Precisamente por esta razón, Pedro CRUZ ha lamentado que no se haya seguido el texto del Anteproyecto de Constitución, que atribuia la iniciativa al Gobierno en su conjunto ${ }^{178}$, con lo cual se hubiera eliminado «un elemento presidencialista suplementario, especialmente innecesario en esta materia» ${ }^{179}$.

Una vez que el Jefe del Gobierno ha adoptado la decisión de proponer la celebración de un referéndum consultivo tiene que solicitar autorización al Congreso de los Diputados, indicando en dicha solicitud "los términos exactos en que haya de formularse la consulta". En cuanto a la valoración política del requisito de que la solicitud contenga expresamente concretada la pregunta que se desea formular, compartimos la opinión del profesor RAMÍREZ, en el sentido de que se ha querido "huir, expresamente, de toda posible ambigüedad y, mucho más, de cualquier tipo de cheque en blanco puesto en manos del Jefe del Ejecutivo» ${ }^{180}$.

\section{2. $\quad$ Autorización del Congreso de los Diputados}

Una vez recibida en la Cámara Baja la solicitud del Presidente del Gobierno, será debatida en el Pleno de la misma. Dicho debate, que deberá ajustarse a las normas previstas para el de totalidad, finalizará con una decisión concreta, que será comunicada por el Presidente del Congreso al

${ }^{176}$ Cfr. Enrique Linde Paniagua y Miguel Herrero Lera: «Comentario a la Ley...», op. cit., p. 95 .

${ }^{177}$ Cfr. Jorge de Esteban: El régimen..., op. cit., p. 97.

178 El artículo 85-3 del Informe de la Ponencia (BOC de 17 de abril de 1978) estaba redactado con el siguiente tenor: «El referéndum será convocado por el Rey, a propuesta del Gobierno, por iniciativa propia o de cualquiera de las Cámaras».

179 Cfr. Pedro CaUz VILLALÓN: “El referéndum...», op. cit., p. 162.

160 Cfr. Manuel RamíRez Jiménez: La participación..., op. cit., p. 134; Idem «Democracia directa...", op. cit., p. 37. 
del Gobierno (art. 161 del Reglamento del Congreso de los Diputados). Sólo si obtiene el voto favorable de la mayoría absoluta de los diputados, el referéndum se entenderá autorizado; en caso contrario, la propuesta del Presidente del Gobierno habrá sido rechazada. Esta regulación suscita algunos comentarios:

- En primer lugar, vemos que el Congreso de los Diputados no sólo debate la conveniencia o no del referéndum, como parecía deducirse del texto del Anteproyecto de Constitución ${ }^{181}$, sino que además tal debate debe concluir necesariamente con una resolución, que de forma inapelable autorizará o prohibirá la convocatoria del referéndum. Como afirma el profesor ALZAGA, en la iniciativa deben coincidir el Gobierno y la Cámara Baja, lo que "evita el peligro de que se convierta en un instrumento al servicio de un Gobierno, más o menos proclive a tentaciones cesaristas, a la hora de afrontar una pugna con las Cortes» ${ }^{182}$.

- En segundo lugar, debemos indicar que la exigencia de que la autorización del Congreso sea por «mayoría absoluta» no venía establecida

181 El artículo 86-2 del Anteproyecto de Constitución una vez dictaminado por la Comisión de Asuntos Constitucionales y Libertades Públicas del Congreso quedó asi: «El referéndum será convocado por el Rey con refrendo del Presidente del Gobierno y previo debate del Congreso de los Diputados" (BOC de 1 de julio de 1978). La expresión "previo debate» era una fórmula extraordinariamente imprecisa que, tal como puso de relieve en el Pleno Heribert Barrera, podía originar grandes ambigüedades: «... es necesario un debate previo en las Cortes. ¿Cómo debe interpretarse esto? ¿El debate tiene que ir seguido de un voto favorable del Congreso o bien basta con que haya debate y la conclusión del debate es indiferente?" (cfr. Diario de Sesiones del Congreso de los Diputados, núm. 109, 13 de julio de 1978, p. 4215).

La Comisión de Constitución del Senado, aceptando la enmienda número 1067 del Grupo Socialista, sustituyó la expresión "previo debate» por «previa autorización» (cfr. Diario de Sesiones del Senado, núm. 50, 6 de septiembre de 1978, pp. 2316, 2317 y 2321). El profesor López Pina justificó este cambio argumentando que era cun servicio a la claridad e inequivocidad que debe caracterizar la relación constitucional entre las instituciones». El artículo, que pasaba a ser el 91, ofrecía la siguiente redacción: «2. El Rey convocará el referéndum, con refrendo del Presidente del Gobierno y previa autorización del Congreso de los Diputados»" ( $B O C$ de 6 de octubre de 1978). Aunque con esta modificación el texto ganaba en claridad, el tema de la iniciativa del referéndum seguía quedando relegado al «limbo de la ambigüedad» (CRUZ VILLALON).

Por último, el Dictamen de la Comisión Mixta Congreso-Senado volvió a retocar la redacción de este precepto, aunque manteniendo las innovaciones introducidas en la Cámara Alta: "El referéndum será convocado por el Rey, mediante propuesta del Presidente del Gobierno, previamente autorizada por el Congreso de los Diputados" (BOC de 28 de octubre de 1978). Lo más novedoso de esta redacción definitiva fue: por una parte, la sustitución de la expresión «con refrendo del Presidente del Gobierno» por la locución «mediante propuesta del Presidente del Gobierno»; y, por otra, el cambio de la fórmula "previa autorización del Congreso" por «previamente autorizada por el Congreso», con lo cual queda claro que la autorización se refiere a la propuesta del Presidente del Gobierno y no a la convocatoria del Rey (CRUZ VILLALON).

${ }_{182}$ Cfr. Oscar Alzaga VILlaAmil: La Constitución..., op. cit., p. 587. 
por la Constitución, sino que fue fijada por el artículo 6 de la Ley Orgánica del Referéndum, lo que suscitó algunas dudas sobre su posible inconstitucionalidad. En nuestra opinión, tal requisito, aunque es evidentemente restrictivo, no puede ser tildado de inconstitucional, pues encuentra cobertura suficiente en los artículos $92-3$ y $79-2$ de la Ley Fundamental ${ }^{183}$. El primero de estos preceptos remite a una ley orgánica la regulación de las "condiciones» de las distintas modalidades de referéndum, y el segundo autoriza a la propia Constitución y a las leyes orgánicas a establecer «mayorías especiales» para adoptar acuerdos en las Cámaras Legislativas. Dejado pues sentado, a la luz de estos preceptos, que esta exigencia de mayoría absoluta no vulnera el Texto Constitucional, debemos añadir que, a nuestro juicio, su introducción resulta altamente positiva, pues supone «un reforzamiento del consenso parlamentario exigido en torno a una consulta de esta naturaleza" ${ }^{184}$. El requisito de la mayoría absoluta es, como afirma el profesor TORRES DEL MORAL, una «garantía» para la oposición y un freno al uso demagógico "de la consulta popular por parte de un Gobierno en dificultades», ya que «impide o dificulta su utilización como un sucedáneo de la confianza parlamentaria” ${ }^{185}$.

- Por otra parte, hay que subrayar que la facultad de autorizar la celebración de un referéndum consultivo se atribuye al Congreso de los Diputados en exclusiva, siendo excluido el Senado como consecuencia del bicameralismo imperfecto que se quiso consagrar. Además, la autorización siempre debe otorgarse con anterioridad a la celebración del referéndum, siendo inadmisibles las hipotéticas convalidaciones a posteriori.

- Finalmente, queremos destacar que el Congreso de los Diputados autoriza o deniega una solicitud del Presidente del Gobierno, pero carece de competencia para proponer de motu proprio la celebración de un referéndum consultivo. Puede, por tanto, impedir su celebración, pero no puede obligar al Presidente del Gobierno a convocarlo ${ }^{186}$.

\section{Convocatoria formal del Rey}

La última fase de este proceso la constituye la convocatoria regia que, como es obvio, tiene carácter totalmente obligatorio ${ }^{187}$. De acuerdo

183 Cfr. Luis AgUIAR dE LUQUE: «La Ley Orgánica...», op. cit., p. 171; Manuel Ramirez JIMÉNEZ: La participación..., op. cit., pp. 134-135; Juan Alfonso SANTAMARIA PASTOR: «Artículo 92», op. cit., p. 1322.

Cfr. Pedro CRuz VILLALON: «El referéndum...", op. cit., p. 163.

185 Cfr. Antonio TorRes del MORAL: Principios..., op. cit., vol. I, p. 122.

186 Con análogo criterio, cfr. Enrique Linde Paniagua y Miguel HerRero Lera: «El referéndum en la Constitución...", op. cit., p. 39; Enrique LINDE PANIAGUA: “Artículo 92...», op. cit., p. 382 .

197 Cfr., entre otros, Jorge de Esteban: El régimen..., op. cit., p. 96. 
con el artículo 2-3 de la Ley Orgánica del Referéndum, dicha convocatoria deberá formalizarse a través de un «Real Decreto acordado en Consejo de Ministros y refrendado por su Presidente».

\subsubsection{Objeto de la consulta: «decisiones políticas de especial trascendencia»}

La delimitación precisa de lo que puede ser objeto de referéndum consultivo es, como se ha puesto de relieve ${ }^{188}$, un tema complejo, pues la fórmula «decisiones políticas de especial trascendencia», que utiliza el artículo 92, adolece de una notable y tal vez premeditada oscuridad. Ya en los debates parlamentarios, Heribert Barrera puso de relieve la ambigüedad que encerraba dicha expresión, preguntándose: «¿Qué quiere esto decir exactamente?, ¿quién puede juzgar de la trascendencia?, ¿con qué criterio?» ${ }^{189}$. A nuestro juicio, los constituyentes consagraron conscientemente un concepto jurídico-político indeterminado, «que evidencia el deseo de dejar en el convocante un margen de libertad de extraordinaria amplitud» ${ }^{190}$. El profesor AGUIAR DE LUQUE ha precisado que por decisión política de especial trascendencia «hay que entender tan sólo eso, decisión básica, cuya puesta en práctica puede implicar tanto una política legislativa acorde, como unas medidas de gobierno congruentes con la voluntad popular expresada en las urnas» ${ }^{191}$. Se ha pretendido, según este mismo autor, que los poderes públicos puedan posteriormente, al concretar la decisión, «ponderar el resultado de la votación popular» ${ }^{192}$.

Es doctrina generalizada ${ }^{193}$ que el referéndum consagrado en el artículo 92 no puede utilizarse para aprobar proyectos de ley ni para derogar leyes en vigor, aunque estos textos contengan decisiones políticas de especial trascendencia. Dos argumentos avalan esta interpretación: por una parte, el propio tenor literal de este precepto» ${ }^{194}$; y, por otra, el desarrollo del proceso constituyente, pues - como sabemos - las dos modalidades de referéndum legislativo fueron expresamente excluidas del Anteproyecto

189 Crf., entre otros, Luis AGUIAR DE LUQUE: «Referéndum», op. cit., p. 794; TORRES DEL Moral, Antonio: Principios..., op. cit., vol. I, pág. 122; Enrique LINDE PANłAGUA: «Artículo 92...», op. cit., pp. 377-78.

${ }_{189}$ Diario de Sesiones del Congreso de los Diputados (Sesión Plenaria), núm. 109, 13 de julio de 1978, p. 4214.

190 Cir. Enrique Linde Paniagua: «Articulo 92...», op. cit., pp. 377-78.

191 Cfr. Luis AgUIAR DE LuQue: «Referendum», op. cit., p. 795.

192 Ibidem, p. 796.

193 En este sentido, cfr. Antonio TORRES MORAL: Principios..., op. cit., vol. I, pp. 121-22; Enrique Linde Paniagua y Miguel Herrero Lera: «El referéndum en la Constitución...», op. cit., pp. 39-40; Luis AGUIAR DE LUQUE: «Referéndum», op. cit., pp. 794-95; Pedro CRUz VILLALÓN: «EI referéndum...», op. cit., pp. 153 y 160; Juan Alfonso SANTAMARIA PASTOR: "Artículo 92», op. cit., pp. 1317-18.

${ }^{194}$ Cfr. Pedro CRuz VILLALÓN: «El referéndum...», op. cit., p. 160; Joaquín TOMÁs VILLARROYA: “Comentario...", op. cit., p. 346. 
de Constitución ${ }^{195}$. En este sentido, debemos indicar que la ubicación del artículo referente al referéndum consultivo en el capítulo dedicado a «la elaboración de las leyes" no tiene ninguna trascendencia jurídica. La razón de esta discutible colocación se debe precisamente a que en los primeros textos del iter legislativo este precepto incluia, junto al referéndum consultivo, el legislativo de ratificación y el legislativo abrogatorio. Al ser suprimidos en la Comisión de Asuntos Constitucionales del Congreso, en vez de repensar el enclave en que debia situarse el ahora ya solitario referéndum consultivo, se mantuvo por inercia en el capítulo dedicado a regular el proceso de elaboración de las leyes, cuando precisamente esta modalidad referendaria no puede tener por objeto textos legislativos.

No obstante lo anterior, debemos señalar que, aunque la pregunta no puede tener un contenido normativo expreso ${ }^{196}$, es muy posible que el resultado del referéndum provoque una determinada actividad legislativa (por ejemplo, en la hipótesis de que el Gobierno sometiera a referéndum su decisión política de despenalizar el aborto, es evidente que el resultado de esta consulta podria motivar la presentación de un proyecto de ley en consonancia con la voluntad popular). Como afirma el profesor TOMÁS VILLARROYA, “el texto literal del artículo 92 puede quedar eludido mediante un expediente fácil: se consulta al pueblo y el resultado de la consulta se articula en un texto legislativo» ${ }^{197}$.

\subsubsection{Alcance y significado del término "consultivo» aplicado a esta modalidad de referéndum}

El tema más importante y a su vez más problemático que plantea el referéndum sobre decisiones políticas del artículo 92, es el de precisar el alcance y significado del término "consultivo", introducido -como sabemos- por la Comisión de Asuntos Constitucionales del Congreso al ser aceptada una enmienda in voce del profesor Solé Tura. Dicho con otras palabras, lo que ahora nos proponemos es determinar si el resultado del referéndum vincula a los poderes públicos o si, por el contrario, sólo tiene carácter orientador, jurídicamente no vinculante.

Para abordar correctamente este problemà resulta imprescindible acudir a los debates parlamentarios, al objeto de saber cuál fue la intención de los constituyentes al calificar de «consultivo» al referéndum sobre decisiones políticas. En primer lugar, hay que subrayar que su propósito fue, sin ninguna duda, el de recortar la eficacia decisoria de este mecanismo de participación directa, aunque no se llegó a precisar claramente en qué

195 Cfr. supra 1.1.1.: «El referéndum en el proceso constituyente».

${ }_{196}$ Cfr. Enrique Linde Paniagua y Miguel Herrero Lera: «El referéndum en la Constitución...", op. cit., p. 39.

${ }_{197}$ Cfr. Joaquín TOMÁs VILLAROYA: “Comentario...”, op. cit., p. 346. 
consistía este recorte. En bastantes momentos de los debates constitucionales, da la impresión de que los parlamentarios que defendian esta innovación (concretamente, Solé Tura y Pérez-Llorca) no se atrevian a decir que el resultado de un referéndum consultivo podia no ser vinculante para los poderes públicos, y soslayaban esta afirmación con diversos rodeos dialécticos ${ }^{198}$. Fue el profesor Fraga Iribarne quien, oponiéndose a la enmienda del profesor Solé Tura, puso el dedo en la llaga, subrayando la "extrema gravedad" que supone someter al pueblo una decisión y luego «no tomar en consideración la opinión expresada» ${ }^{199}$. Ante estas críticas, los defensores de introducir el término "consultivo" precisaron algo más lo que significaba para ellos este vocablo. El profesor Solé Tura parecía concebir el referéndum consultivo como un gran sondeo de opinión. A su juicio, este tipo de referéndum debería utilizarse cuando, ante situaciones extraordinarias, haya que adoptar decisiones politicas de especial trascendencia que ni el Gobierno ni las Cortes «quieran asumir con plenitud sin saber exactamente cuál es el estado de la opinión, y que se pueda levantar acta de esta opinión" ${ }^{200}$. Por su parte, José Pedro Pérez-Llorca fue todavía mucho más claro. A su entender, el calificar de consultivo al referéndum sobre decisiones políticas traía como consecuencia que, si el nivel de abstención era muy elevado, los poderes públicos no estarían obligados a seguir la opinión mayoritaria, pues ésta no reflejaría realmente la voluntad popular ${ }^{201}$. La réplica de Heribert Barrera al diputado de UCD fue inmediata. “¿Cómo puede imaginarse - decía- que se hará una consulta al pueblo, que el pueblo contestará en un cierto sentido y que luego no se le hará caso?». Tras agregar que este mecanismo puede dar lugar a «conflictos gravísimos», concluía diciendo que, en un sistema democrático, es inadmisible «pensar que alguien puede oponerse a la voluntad del pueblo, expresada en referéndum» ${ }^{202}$. Hasta aquí lo que dieron de sí los oscuros

${ }^{198}$ El profesor Jordi Solé Tura se expresó en los siguientes términos: el referéndum sobre "decisiones politicas de especial trascendencia, si no se matiza, puede dar lugar también a que el Parlamento quede abasolutamente colocado en un segundo plano y, desde luego, establecemos una dinámica que puede prácticamente, no sólo establecer grandes conflictos entre los diversos poderes, sino reducir también al Parlamento a un papel absolutamente mínimo". Cfr. Diario de Sesiones del Congreso de los Diputados (Comisión de Asuntos Constitucionales y Liberales Públicas), núm. 81, 6 de junio de 1978, p. 2937.

El diputado centrista José Pedro Pérez-Llorca Rodrigo, al adherirse a la propuesta del profesor Solé Tura, afirmó: "la explicitación del carácter consultivo de este referéndum decisionista, parece también una mejora desde nuestra actual contemplación del problema.» Cfr. Diario de Sesiones del Congreso de los Diputados '(Comisión de Asuntos Constitucionales y Libertades Públicas), núm. 81, 6 de junio de 1978, p. 2940.

${ }_{199}$ Diario de Sesiones del Congreso de los Diputados (Comisión de Asuntos Constitucionales y Libertades Públicas), núm. 81, 6 de junio de 1978, p. 2941; y Diario de Sesiones del Congreso de los Diputados (Sesión Plenaria), núm. 109, 13 de julio de 1978, p. 4212.

200 Diario de Sesiones del Congreso de los Diputados (Comisión de Asuntos Constitucionales y Libertades Públicas), núm. 81, 6 de junio de 1978, p. 2942.

201 Diario de Sesiones del Congreso de los Diputados (Sesión Plenaria), núm. 109, 13 de julio de 1978, p. 4213.

${ }_{202}$ Diario de Sesiones del Congreso de los Diputados (Sesión Plenaria), núm. 13 de julio de 1978, pp. 4214-15. 
debates parlamentarios en torno al significado del término «consultivo» aplicado al referéndum sobre decisiones políticas.

Por otra parte, dentro del ámbito doctrinal, se han defendido tres interpretaciones parcialmente distintas sobre el alcance que hay que atribuir a dicho término:

a) Para algunos autores el resultado de un referéndum consultivo no vincula juridicamente a los poderes públicos que, en consecuencia, podrán actuar en sentido contrario al preferido por la mayoria de los ciudadanos. El profesor ALZAGA VILLAAMIL defiende esta interpretación, pero la matiza afirmando que «si el pueblo se manifiesta en términos muy netos en favor de una determinada opción, no es de prever, en el terreno del realismo político, que» el Gobierno o el Parlamento «se aventuren a ir contra la opinión popular manifestada a través de tal vía» ${ }^{203}$.

b) Para otro sector de la doctrina, el referéndum no tendrá carácter vinculante cuando los resultados del mismo muestren «una ciudadanía escindida a nivel de votos», pero, en cambio, la obligatoriedad será total cuando una de las dos respuestas haya «alcanzado una amplia mayoría en el cuerpo electoral» ${ }^{204}$.

c) Finalmente, para un tercer grupo de autores - cuya opinión nosotros suscribimos - el resultado del referéndum es jurídicamente vinculante, con independencia de que la mayoria haya sido amplia o ajustada, $y$, por tanto, los poderes públicos están totalmente obligados por aquel resultado. Hacer caso omiso del mismo equivaldria - como ha afirmado gráficamente el profesor DE ESTEBAN- a un «verdadero golpe de Estado constitucional, puesto que el sujeto de la soberanía, en última instancia, es el pueblo y él debe ser quien tenga la última palabra en los asuntos de Estado sobre los que se le consulta" ${ }^{205}$. Como señala, en esta misma línea, el profesor TORRES DEL MORAL, «está fuera de lugar que al pueblo se le asigne una función de consejo. Cuando el pueblo habla, no aconseja, ni sugiere, ni recomienda: decide» ${ }^{206}$. Y nosotros añadimos: ¿cómo osarian

203 Cfr. Oscar Alzaga VILlaAmil: La Constitución..., op. cit., p. 587. El profesor Joaquín TOMÁS VILLARROYA ( Comentario...», op. cit., p. 346), también parece suscribir, de forma matizada, esta lectura: «el resultado del referéndum no vincula al órgano que debe adopatar la decisión consultada; pero, politicamente, parece difícil imaginar que tal órgano ignore el resultado."

204 Cfr. Manuel Ramíaez Jiménez: La participación..., op. cit., pp. 125-26. Análoga interpretación parece asumir el profesor Juan Alfonso SANTAMARIA PASTOR («Artículo 92», op. cit., p. 1317), cuando afirma que «resulta impensable que el órgano que hubiese de adoptar la decisión consultada lo hiciese en un sentido contrario al pronunciamiento neto y rotundo de la voluntad popular».

205 Cfr. Jorge oe Esteban: El régimen..., op. cit., p. 97.

206 Cfr. Antonio Torres Moral: Principios..., op. cit., vol. l, p. 122. 
el Gobierno o el Parlamento ir en contra de la opinión mayoritaria del cuerpo electoral, del que ellos son emanación?

Dentro del grupo de autores que defienden el carácter rigurosamente vinculante del resultado de un referéndum consultivo, destaca por su solidez argumental la construcción elaborada por los profesores Jorge ESTEBAN y Luis LOPEZ GUERRA con motivo del referéndum sobre la Alianza Atlántica ${ }^{207}$. Comienzan su exposición precisando que este tipo de referéndum debe recaer siempre sobre decisiones políticas previamente adoptadas por los órganos pertinentes y, fundamentalmente, por el Gobierno de la Nación. El esquema lógico que ha dibujado la Constitución -agregan estos autores - podría «resumirse diciendo que el Gobierno toma o anuncia una decisión y el pueblo se pronuncia sobre ella, favorable o desfavorablemente». El carácter consultivo del referéndum no significa que "el Gobierno haya de limitarse a tomar nota» y todo continúe como si no hubiera ocurrido nada. Por el contrario, a juicio de los profesores DE ESTEBAN y LOPEZ GUERRA, «la fuerza vinculante de un pronunciamiento popular, en un Estado definido constitucionalmente como democrático, no puede ser objeto de discusión, salvo que se cuestione el mismo contenido de la democracia". Sin embargo, acto seguido, aclaran que esta indiscutible fuerza vinculante «debe considerarse desde la perspectiva del objeto mismo del pronunciamiento popular". Aplicando estas premisas al referéndum sobre decisiones políticas del artículo 92, obtienen las siguientes conclusiones:

a) Si la mayoría de los ciudadanos da su apoyo a la decisión adoptada por el Gobierno, éste está obligado a "su cumplimiento o puesta en práctica, en los mismos términos en que se hizo la pregunta».

b) El voto contrario, en cambio, supone «una oposición mayoritaria a una actuación política concreta» del Ejecutivo, sobre un tema que - no lo olvidemos- es de «especial trascendencia». Ante una situación de este tipo, los autores del trabajo que estamos analizando creen que se dan dos posibles salidas constitucionales:

1. ${ }^{a}$ Si el Gobierno considera que aquella decisión que ha sido rechazada por los ciudadanos forma parte esencial de su programa gubernamental, deberá disolver el Parlamento y convocar elecciones generales. Ya que si es evidente que el Ejecutivo está vinculado por la decisión popular, también lo es que no puede ser obligado a actuar contra sus convicciones más profundas, y hay que darle la posibilidad de que abandone

${ }^{207}$ Cfr. Jorge de Esteban y Luis LOPEz GuerRa: «Referéndum consultivo y decisión política», en el diario El País, 30 de enero de 1986, pp. 11-12. 
el Poder. Visto desde otra perspectiva, esta convocatoria de elecciones anticipadas ofrecerá, a esta mayoría de ciudadanos contrarios a la decisión política sometida a referéndum, «la posibilidad de conformar una mayoría parlamentaria y un Gobierno capaces de ejecutar o llevar a cabo una decisión distinta a la que fue objeto de consulta».

2. ${ }^{a} \quad$ La segunda salida constitucional se da cuando el Gobierno que ha perdido un referéndum consultivo considera que dicho resultado adverso "no afecta esencialmente a su programa global» $y$, en consecuencia, en vez de disolver el Parlamento, prefiere urevocar su decisión anterior y adoptar una nueva en consonancia con la voluntad popular mayoritaria».

Tanto si el Gobierno opta por una como por otra solución, es evidente que los resultados del referéndum le han vinculado. Como afirman los profesores DE ESTEBAN y LÓPEZ GUERRA al concluir su trabajo, los electores, a través de este instrumento, "se convierten en sujetos constitucionales, directamente activos respecto a una decisión trascendente».

\subsection{Referéndums autonómicos}

\subsubsection{Introducción}

Llamamos referéndums autonómicos a aquellos que tienen su ámbito territorial y humano circunscrito a una Comunidad Autónoma y que, de una u otra forma, están insertos en el proceso de configuración del Estado autonómico. Se trata, sin duda, de la modalidad referendaria que «mayor eco" ha encontrado en nuestra actual Constitución ${ }^{208}$, ya que se han introducido cuatro variantes de la misma: $1 .^{\mathrm{a}}$ referéndum para que una proyectada Comunidad Autónoma pueda acceder a la autonomía plena por la vía rápida sin reunir los requisitos que exige la disposición transitoria segunda (art. 151-1); $2{ }^{a}$ referéndum para aprobar los Estatutos de autonomía de los territorios que sigan la vía rápida (art. 151-2); $3{ }^{a}$ referéndum para modificar los estatutos de autonomía de las Comunidades Autónomas que hayan seguido la vía rápida (art. 152-2); y $4 .^{a}$ referéndum para la incorporación de Navarra a la Comunidad Autónoma Vasca (disposición transitoria cuarta). Estos cuatro tipos de referéndums autonómicos son rigurosamente obligatorios para poder alcanzar la consecuencia jurídica deseada (es decir, sin referéndum afirmativo no se podrá acceder directamente a la autonomía plena sin ser Comunidad histórica, no se podrá aprobar o reformar el estatuto de autonomía de una Comunidad especial, ni se podrá incorporar Navarra a la Comunidad Autónoma Vasca). 
A pesar de esta pluralidad de referéndums regionales, debemos indicar que realmente no se ha perseguido con ellos incrementar los cauces de participación directa de los ciudadanos en la vida política, sino más bien dar un sólido fundamento democrático a «una decisión de tanta trascendencia como es la que toca al proceso autonómico, base de la descentralización del Estado» ${ }^{209}$. Sin embargo, hay que añadir para ser exactos que las tres modalidades principales de referéndum regional (dejamos ahora aparte el caso sui generis de Navarra) no debian utilizarse en todas las Comunidades, sino sólo en aquellas que habían accedido o pretendían acceder a la autonomía plena por la vía rápida. Es evidente, por otra parte, que, al haberse concluido el proceso de construcción del Estado autonómico, los preceptos que consagran las dos primeras modalidades de referéndum regional ya han agotado sus efectos, pues, aunque están ubicados en el texto articulado, son verdaderas normas de Derecho transitorio ${ }^{210}$.

Por lo que se refiere a la experiencia práctica de los referéndums autonómicos, debemos subrayar que la mayoría de los autores la han valorado en términos negativos, aunque normalmente han precisado que las deficiencias se han debido a causas ajenas a la propia institución referendaria. En esta línea crítica, el profesor TOMÁS VILLARROYA ha señalado que «la convocatoria del referéndum para la ratificación de los Estatutos catalán y vasco se realizó de manera inconstitucional», que el referéndum andaluz de iniciativa autonómica motivó manipulaciones contrarias a la Constitución en la Ley Orgánica $2 / 1980$, y, finalmente, que «la trayectoria del Estatuto gallego rompió literalmente el artículo $151 \mathrm{y}$, a la postre, concluyó en un voto con tal grado de abstención que debiera obligar a la meditación" ${ }^{211}$. Sin ningún propósito de exhaustividad, expondremos, a continuación, algunos de los aspectos más destacados de estos cuatro tipos de referéndums autonómicos.

\subsubsection{Referéndum para que una proyectada Comunidad Autónoma pueda} acceder a la autonomía plena por la vía rápida sin reunir los requisitos que exige la disposición transitoria segunda (art. 151-1)

Los territorios que durante la Segunda República no habian plebiscitado afirmativamente proyectos de estatuto de autonomía sólo podían asumir desde el principio el techo competencial máximo, fijado para las Comunidades históricas, si conseguían superar los obstáculos que establecia

${ }^{209}$ Cfr. Jorge de EsteBAN: El régimen..., op. cit., p. 97.

210 Cfr. Antonio Torres del Moral: Principios..., op. cit., vol. I, p. 110.

211 Cfr. Joaquin Tomas VIllarroya: «Comentario...», op. cit., p. 346; Idem: «Proceso autonómico...", op. cit., pp. 25-64. 
el primer párrafo del artículo 151 de la Constitución ${ }^{212}$. Entre dichos obstáculos, el más dificil de franquear era, sin duda, la necesidad de que la iniciativa fuera «ratificada mediante referéndum por el voto afirmativo de la mayoría absoluta de los electores de cada provincia". El artículo 8-4 de la Ley Orgánica 2/1980, de 18 de enero, sobre regulación de las distintas modalidades de referéndum, precisó que, "celebrado el referéndum, si no llegase a obtenerse la ratificación por el voto afirmativo de la mayoría absoluta de los electores de cada provincia», no podria «reiterarse la iniciativa hasta transcurridos cinco años». Andalucía, como es sabido, inició su proceso autonómico por la vía del artículo 151; sin embargo, el referéndum del 28 de febrero de 1980 se frustró al no obtener el quórum suficiente en la provincia de Almeria ${ }^{213}$. Al objeto de dar una solución definitiva a la delicada situación política que se habia creado, el Parlamento -en medio de tensiones y proposiciones dispares- aprobó la Ley Orgánica 12/1980, de

212 El primer párrafo del artículo 151 de la Constitución está redactado con el siguiente tenor: «No será preciso dejar transcurrir el plazo de cinco años a que se refiere el apartado 2 del articulo 148, cuando la iniciativa del proceso autonómico sea acordada dentro del plazo del articulo 143-2, además de por las diputaciones o los órganos interinsulares correspondientes, por las tres cuartas partes de los municipios de cada una de las provincias afectadas que representen, al menos, la mayoría del censo electoral de cada una de ellas y dicha iniciativa sea ratificada mediante referéndum por el voto afirmativo de la mayoría absoluta de los electores de cada provincia en los términos que establezca una ley orgánica».

«No queda claro - como afirma el profesor DE ESTEBAN — si tal acopio de obstáculos se ha establecido con la idea de poner rotundamente de manifiesto esa mayor conciencia particularista o, por el contrario, de lo que se trataba era de dificultar al máximo esta vía rápida a fin de que fuese prácticamente imposible su utilización». Cfr. Jorge DE ESTEBAN: El régimen constitucional español 2, Labor Universitaria, Barcelona 1982, p. 360.

${ }^{213}$ El referéndum celebrado el 28 de febrero de 1980 en Andalucía fue el único que se convocó para reiterar una iniciativa autonómica. Sus resultados - en porcentajes sobre el censo-fueron los siguientes:

\begin{tabular}{|l|c|c|c|}
\hline \multicolumn{1}{|c|}{ PRovincias } & votos sı & votos No & votos blanco \\
\hline Almería & 47,00 & 4,02 & 4,40 \\
\hline Cádiz & 55,38 & 2,01 & 3,64 \\
\hline Córdoba & 60,09 & 3,90 & 5,29 \\
\hline Granada & 52,73 & 3,78 & 5,38 \\
\hline Huelva & 52,80 & 2,16 & 4,10 \\
\hline Jaén & 50,07 & 6,20 & 6,27 \\
\hline Málaga & 50,77 & 3,08 & 3,24 \\
\hline Sevilla & 65,17 & 2,99 & 4,27 \\
\hline
\end{tabular}

Para el estudio de los aspectos jurídicos y políticos de esta consulta popular, pueden verse, entre otros, los siguientes trabajos: Pilar DEL CASTILLO VERA: "Referéndum en Andalucia en aplicación del artículo 151 de la Constitución», en Revista del Departamento de Derecho Político, núm. 6, primavera 1980, pp. 175-79; Joaquín TOMÁs VILLARROYA: «Proceso autonómico...", op. cit., pp. 37-52; Luis OrTEGa Alvarez: «La inconstitucionalidad de...", op. cit., pp. $171-204$. 
16 de diciembre, que añadía dos nuevos párrafos al artículo 8-4 de la Ley Orgánica 2/1980, reguladora de las distintas modalidades de referéndum:

«Celebrado el referéndum, si no llegase a obtenerse la ratificación por el voto afirmativo de la mayoria absoluta de los electores de cada provincia, no podrá reiterarse la iniciativa hasta trascurridos cinco años.

Esto no obstante, la iniciativa autonómica prevista en el artículo 151 se entenderá ratificada en las provincias en las que se hubiere obtenido la mayoría de votos afirmativos previstos en el párrafo anterior, siempre y cuando los votos afirmativos hayan alcanzado la mayoria absoluta del censo de electores en el conjunto del ámbito territorial que pretenda acceder al autogobierno.

Previa solicitud de la mayoría de los diputados y senadores de la provincia o provincias en las que no se hubiere obtenido la ratificación de la iniciativa, las Cortes Generales, mediante ley orgánica, podrán sustituir la iniciativa autonómica prevista en el artículo 151 siempre que concurran los requisitos previstos en el párrafo anterior» ${ }^{214}$.

Con dicha innovación, calificada de inconstitucional prácticamente por toda la doctrina ${ }^{215}$, se podian estimar afirmativos los resultados negativos del referéndum andaluz ${ }^{216}$. Como ha afirmado el profesor Luis ORTEGA, la Ley Orgánica 12/1980 «constituye una auténtica ley medida, en cuanto que confiere rango normativo a los caracteres concretos" que acompañaron al referéndum andaluz de iniciativa autonómica ${ }^{217}$.

1.4.3. Referéndum para aprobar los estatutos de autonomía de los territorios que sigan la vía rápida (art. 151-2)

La opción por la via del artículo 143 o por la del artículo 151 no sólo comportaba diferencias en el ritmo de acceso al techo competencial má-

214 La Ley Orgánica 12/1980, de 16 de diciembre, se publicó en el Boletín Oficial del Estado del día 24 de diciembre de 1980.

215 Cfr., entre otros, Antonio Torres del Moral: Principios..., op. cit., vol. I, p. 114; Joaquín TOMAS VILLARROYA: “Proceso autonómico...", op. cit., pp. 39-42 y 50-53; Idem: “Comentario...", op. cit., p. 346; Manuel Ramirez Jiménez: La participación..., op. cit., pp. 130-131; Luis ORTEGA ÁlvaREZ: “La inconstitucionalidad...», op. cit., pp. 203-204.

${ }_{216}^{21}$ La Ley Orgánica 12/1980 incluía una disposición transitoria que le daba efectos retroactivos, con el fin de posibilitar su aplicación a Andalucia. «Lo dispuesto en la presente Ley —decía- será de aplicación a los referéndums de ratificación de la iniciativa autonómica celebrados con anterioridad a su entrada en vigor y desde la vigencia de la Constitución".

${ }_{217}$ Cfr. Luis OrTega Alvarez: "La inconstitucionalidad de...», op. cit., p. 171. Con idéntico criterio, Santiago MuÑoz MaCHado (Derecho Público de las Comunidades Autónomas l, Civitas, Madrid 1982, p. 258) ha afirmado: «La envergadura política del problema, después de diversos avatares, hizo que se buscara una solución particular que, aunque arropada en la forma de una modificación de la Ley Orgánica del Referéndum, consistió en la aprobación de una auténtica ley medida para el caso andaluz». 
ximo, sino que también repercutía en la forma de elaborarse y aprobarse el correspondiente estatuto ${ }^{218}$. Los territorios que podian alcanzar directamente el grado máximo de autogobierno, bien por haber plebiscitado afirmativamente proyectos de estatuto de autonomía durante la Segunda República (caso de Cataluña, País Vasco y Galicia) o bien por haber superado los obstáculos establecidos en el primer párrafo del articulo 151 (caso de Andalucia), debian someter sus proyectos de estatuto de autonomía a «referéndum del cuerpo electoral de las provincias comprendidas en el ámbito territorial del proyectado estatuto" (art. 151-2, $3 .^{\circ}$ y $5 .^{\circ}$ ).

El procedimiento para elaborar el estatuto de autonomía de los territorios que seguian la vía rápida está básicamente regulado en los cinco párrafos del artículo 151-2 de la Constitución y en el artículo 9 de la Ley Orgánica del Referéndum. Por razones obvias no vamos a entrar en el estudio de estos complejos trámites. Ahora sólo queremos subrayar que - tanto si habia acuerdo entre la Comisión Constitucional del Congreso y la delegación de la Asamblea de parlamentarios regionales como si no to habia y, en consecuencia, el proyecto de estatuto debía tramitarse como un proyecto de ley- el texto propuesto debía gozar del respaldo popular manifestado a través de un referéndum afirmativo. En torno a este referéndum, que ya se exigía en el artículo 12 de la Constitución republicana de $1931^{219}$, queremos destacar que el quórum necesario de respuestas afirmativas era sensiblemente inferior al que se requeria en el referéndum para ratificar la iniciativa autonómica. En este último supuesto era preciso, como hemos visto, que en cada provincia hubieran votado afirmativamente «la mayoría absoluta de los electores», en cambio para aprobar los estatutos de autonomía era suficiente "la mayoría de los votos válidamente emitidos en cada provincia” (art. 151-2, $4 .^{\circ}$ y $5 .^{\circ}$ de la Constitución y art. 92 de la LOR). Es evidente, pues, que en el referéndum que ahora estamos analizando no se demandaba quórum mínimo de participación, y era suficiente con que la mitad más uno de los votos válidos hubiera sido

${ }^{218}$ Cfr. Jorge DE Esteban: El régimen..., op. cit., vol. II, pp. 355 y 365.

219 El artículo 12-b de la Constitución de 1931 señalaba que para la aprobación del estatuto de una región autónoma era preciso que lo aceptasen, por el procedimiento que señalase la ley electoral, "por lo menos las dos terceras partes de los electores inscritos en el censo de la región". Añadia este precepto que, si el plebiscito era negativo, no podía "renovarse la propuesta de autonomía hasta transcurridos cinco años". En la breve etapa republicana se llegaron a celebrar tres referéndums autonómicos, todos ellos con resultados positivos: el 2 de agosto de 1931 en Cataluña (porcentaje de votos favorables sobre el censo: 74,86 ), el 5 de noviembre de 1933 en el País Vasco (porcentaje de votos favorables sobre el censo: 84,05) y el 28 de junio de 1936 en Galicia (porcentaje de votos favorables sobre el censo: 73,96). Como señala el profesor HERnÁNDEZ LAFUENTE, destaca el «elevado porcentaje de votantes que acudieron a las urnas para manifestar su voluntad autonomista, superándose en los tres referéndums celebrados durante el periodo republicano el nivel de participación conseguido en las tres elecciones que en el mismo se convocaron... los datos revelan una inequivoca voluntad y entusiasmo en la actuación colectiva de estos pueblos que se movilizaron unánimemente por su autonomia». Cfr. Adolfo HERNANDEZ LAFUENTE: «Los referéndums de autonomía...", op. cit., pp. 97-119; Luis AguIAR DE LuQUE: Democracia..., op. cit., pp. 244-251. 
favorable al texto estatutario propuesto, hecho este cómputo provincia por provincia ${ }^{220}$. Este tipo de referéndum regional se ha utilizado en cuatro Comunidades Autónomas (Cataluña, Euskadi, Galicia y Andalucía) y en todas ellas, con diferentes porcentajes de participación y apoyo, los resultados han sido positivos ${ }^{221}$.

1.4.4. Referéndum para modificar los estatutos de autonomía de las Comunidades Autónomas que hayan seguido la via rápida (art. 152-2)

Los estatutos de autonomía que se han elaborado y aprobado siguiendo los trámites preceptuados en el artículo 151-2 -esto es, los de las Comunidades que han seguido la vía rápida- «solamente podrán ser modificados mediante los procedimientos en ellos establecidos y con referéndum entre los electores inscritos en los censos correspondientes» (art. 1522 de la Constitución). El artículo 10 de la Ley Orgánica 2/1980 precisa que este referéndum requerirá el cumplimiento previo de los trámites de reforma establecidos en el estatuto de autonomía que se quiera modificar, 0 , «en su defecto, de los que fueran precisos para su aprobación, debiendo ser convocado (el referéndum) en el plazo de seis meses desde el cumplimiento de los mismos».

220 Cfr. Enrique Linde Paniagua y Miguel Herrero Lera: “El referéndum en la Constitución...", op. cit., p. 44.

221 La convocatoria de los referéndums sobre los Estatutos vasco y catalán se hizo, ante la falta de desarrollo legisiativo del articulo 92-3 de la Constitución, por la vía del decretoley (Real Decreto-ley 13/1979 y Real Decreto-ley 14/1979, ambos de 14 de septiembre). Esta técnica suscitó en la doctrina serias dudas sobre su corrección constitucional. Cfr. Enrique LINDE PANIAGUA: "Anotaciones a los Decretos-leyes de convocatoria de los referéndums autonómicos en el Pais Vasco y Cataluña: vigencia de la Constitución y reserva de ley orgánica", en Revista de Administración Pública, núm. 89, 1979, pp. 411-417; Joaquín TOMAs VILLARROYA: «Proceso autonómico...", op. cit., pp. 26-30.

Los resultados que se produjeron en los cuatro referéndums celebrados en aplicación del segundo párrato del artículo 151 de la Constitución fueron los siguientes (en porcentajes sobre los votantes):

A) Cataluña (25-X-1979): Sí $(88,1)$, No $(7,8)$, Blanco $(3,5)$ y Nulos $(0,5)$. Cfr. EQUIPO DE SOCIOLOGIA ELECTORAL DE LA UNIVERSIDAD AUTONOMA DE BARCELONA: «EI referéndum del Estatuto de Autonomia en Cataluña», en Revista de Estudios Políticos, núm. 12, 1979, pp. 197-213; Fernando OLLERO BUTLER: «El referendum para la autonomía de Cataluña», en Revista del Departamento de Derecho Político, núm. 5, invierno 1979-1980, pp. 213-225.

B) Euskadi (25-X-1979): Si $(90,2)$, No $(5,1)$, Blanco $(3,4)$ y Nulos $(1,1)$. Cfr. Pilar dEL. Castillo Vera: “Referéndum del Estatuto de Autonomia en el Pais Vasco», en Revista del Departamento de Derecho Político, núm. 5, invierno 1979-1980, pp. 201-211; Javier CoRCUERA Atienza y Alberto Pérez Calvo: «En torno al referéndum del Estatuto de Autonomía del País Vasco. Notas sobre el subsistema de partidos vascos», en Revista de Estudios Políticos, núm. 12, 1979, pp. 179-196.

C) Galicia (21-XII-1980): Sí (73,3), No $(19,7)$, Blanco $(4,6)$ y Nulos $(2,2)$. Cfr. Santiago SANCHEZ GonZÁLEZ: "Referéndum sobre el Estatuto de Autonomía de Galicia", en Revista de Derecho Politico, núm. 9, primavera 1981, pp. 219-220.

D) Andalucía (20-X-1981): Si $(89,3)$, No (7), Blanco $(2,8)$ y Nulos $(0,7)$. Cfr. Pilar MelLado PRADo: «El referéndum sobre el Estatuto de Autonomía andaluz», en Revista de Derecho Político, núm. 13, primavera 1982, pp. 213-215. 
El requisito constitucional de que cualquier reforma de los estatutos elaborados por la vía del artículo 151-2 deba ser ratificada por el pueblo, a través de un referéndum, ha sido recogido y desarrollado por los cuatro estatutos de autonomia de las Comunidades especiales (arts. 56 y 57 del Estatuto catalán, arts. 46 y 47 del Estatuto vasco, arts. 56 y 57 del Estatuto gallego y arts. 74 y 75 del Estatuto andaluz). Con este requisito, justificado por el hecho de que su aprobación también requirió la participación directa de los ciudadanos ${ }^{222}$, se ha querido acentuar el carácter rigido de la «norma institucional básica» de la Comunidad Autónoma ${ }^{223}$. Por otra parte, aunque ni la Constitución ni la Ley Orgánica del Referéndum han previsto el quórum preciso para ratificar la reforma de los estatutos, parece lógico entender que se exigirá el mismo porcentaje que se demandó para aprobarlos (esto es, la mayoría de los votos válidamente emitidos), y también parece evidente que el cómputo deberá efectuarse provincia por provincia ${ }^{224}$.

Añadamos a lo anterior que el Estatuto de Autonomia.del País Vasco contiene, en el tercer apartado del artículo 47, un tipo sui generis de referéndum de reforma estatutaria: el exigido para suprimir el artículo 17-6-b inciso segundo ${ }^{225}$, que faculta a los Cuerpos y Fuerzas de Seguridad del Estado a intervenir en Euskadi, bajo la responsabilidad exclusiva del Gobierno de la Nación, "en supuestos de especial urgencia» ${ }^{226}$.

Para concluir este epígrafe queremos plantear la cuestión de determinar si los estatutos de las Comunidades -Autónomas de segundo grado hubieran podido exigir, amparándose en la cláusula abierta del artículo 147-3, que la reforma de los mismos fuera aprobada en referéndum entre los electores inscritos en los censos correspondientes ${ }^{227}$. En torno a este tema hay que subrayar que la doctrina se ha mostrado dividida. Mientras que algunos autores se inclinan por aceptar esta posibilidad invocando «la li-

222 Cfr. Jorge de Esteban: El régimen..., op. cit., vol. I, p. 98 y vol. II, p. 369.

${ }^{223}$ Con análogo criterio, cfr. Pedro CRUZ VILLALÓN: «El referéndum...», op. cit., p. 165

${ }^{224}$ El artículo 5-2 de la Ley Orgánica del Referéndum, ubicado en el epigrafe dedicado a "Disposiciones generales», precisa que «la circunscripción será, en todo caso, la provincia».

${ }_{225}$ El artículo 47-3 del Estatuto vasco, situado en el capítulo IV bajo el título «De la reforma del Estatuto", está redactado con el siguiente tenor: “El segundo inciso de la letra b) del número $6 \mathrm{del}$ artículo $17 \mathrm{del}$ Estatuto podrá ser suprimido por mayoría de tres quintos del Congreso y el Senado y aprobación del Parlamento Vasco, con posterior referéndum convocado al efecto, debidamente autorizado".

${ }_{226}$ El articulo 17-6- $b$-inciso segundo del Estatuto de Euskadi dice asi: «En supuestos de especial urgencia y para cumplir las funciones que directamente les encomienda la Constitución, los Cuerpos y Fuerzas de Seguridad del Estado podrán intervenir bajo la responsabilidad exclusiva del Gobierno, dando éste cuenta a las Cortes Generales. Las Cortès Generales, a través de los procedimientos constitucionales, podrán ejercitar las competencias que les corresponda".

${ }^{227}$ Cfr. Joan Oliver Araujo: «La reforma del Estatuto de Autonomía para las Islas Baleares", en Cuadernos de la Facultad de Derecho, núm. 11, 1985, pp. 102-103. 
bertad que al respecto establece el artículo 147-3» ${ }^{228}$, otro sector doctrinal estima que seria "poco consecuente" interpretar los preceptos constitucionales en el sentido de admitir que fuese más agravado el procedimiento de reforma de un precepto cualquiera del Estatuto, por insignificante que fuera, que el de aprobación del Estatuto entero (que, como sabemos, en las Comunidades de vía lenta no exige referéndum) ${ }^{229}$.

\subsubsection{Referéndum para la incorporación de Navarra a la Comunidad Autónoma Vasca (disposición transitoria cuarta)}

La provincia de Navarra - por sus peculiaridades históricas, políticas y culturales - fue "objeto de una previsión singular» ${ }^{230}$ en la disposición transitoria cuarta de la Constitución. En el primer párrafo de la misma se establece que, a efectos de su posible incorporación a la Comunidad Autónoma Vasca, "en lugar de lo que establece el artículo 143 de la Constitución, la iniciativa corresponde al Órgano Foral competente -esto es, al Parlamento de Navarra ${ }^{231}$ _, el cual adoptará su decisión por mayoría de los miembros que lo componen. Para la validez de dicha iniciativa - sigue diciendo este precepto- será preciso, además, que la decisión del Órgano Foral competente sea ratificada por referéndum expresamente convocado al efecto, y aprobado por mayoría de los votos válidos emitidos». Lo primero que debemos señalar es que el procedimiento de integración de Navarra en Euskadi es, en la actualidad, impracticable, pues no ha encontrado el más mínimo desarrollo ni en la Ley Orgánica del Referéndum ni en la Ley Orgánica de Reintegración y Amejoramiento del Régimen Foral de Navarra ${ }^{232}$.

En torno al referéndum previsto en la disposición transitoria cuarta de la Constitución - que trạe su causa inmediata en el Real Decreto-ley 2/ 1978 , de 4 de enero ${ }^{233}$ - podemos destacar los siguientes aspectos:

228 Cfr. Rafael EnTRENA CueSTA: “Artículo 147», en Comentarios a la Constitución, Civitas, Madrid 1980, p. 1600. En el mismo sentido, cfr. Antonio TORRES DEL MORAL: Principios..., op. cit., vol. I, p. 127.

229 Cfr. Santiago MuÑoz Machado: Derecho Público..., op. cit., p. 307.

2so Ibidem, p. 276.

231 El articulo primero del Real Decreto 121/1979, de 26 de enero, precisó que el «Organo Foral competente» a que alude la disposición transitoria cuarta de la Constitución es el Parlamento Foral de Navarra.

${ }^{232}$ Cfr. Antonio TORRES del MORAL: Principios..., op. cit., vol. I, pp. 109-110; Luis AgulaR DE LuQue: «Referéndum», op. cit., p. 797; Juan Alfonso SANTAMARÍA PASTOR: "Artículo 92", op. cit., p. 1320.

${ }^{233}$ El Real Decreto-ley 2/1978, de 4 de enero (BOE 6-I-1978), que regulaba el procedimiento para decidir la incorporación de Navarra al Consejo General del País Vasco, precisaba que «en el caso de que el Órgano Foral competente decidiese aprobar la presencia de Navarra en el Consejo General del País Vasco, será necesario, para que tal acuerdo alcance validez, que esta decisión sea ratificada por el pueblo navarro mediante consulta popular directa a través del procedimiento y en los términos que determine el Gobierno de acuerdo con la Diputación Foral» (art. 2). 
1. Para la validez de la iniciativa es preciso que la decisión de las Cortes de Navarra sea ratificada en referéndum por la mayoría de los votos válidamente emitidos. Como vémos, lejos de establecerse las dificultades extremas del artículo 151-1, se exige el mismo porcentaje de apoyo popular que el demandado para aprobar los estatutos de autonomía de los territorios que han seguido la vía rápida (art. 151-2).

2. Aunque la disposición transitoria cuarta no precisa el ámbito territorial y personal de esta consulta, parece claro, como afirman los profesores LINDE PANIAGUA y HERRERO LERA, que «es el de la provincia de Navarra y el cuerpo electoral de la citada provincia» ${ }^{234}$.

$3^{\circ} \quad$ En tercer lugar, debemos subrayar que, de acuerdo con el precepto que estamos comentando, la iniciativa de incorporación adoptada por el Parlamento navarro debe ratificarse en «referéndum expresamente convocado al efecto». Lo que comporta que esta consulta no podrá «acumularse a otras ni entenderse incluida en una más amplia" ${ }^{235}$.

4. Indiquemos, por otra parte, que el segundo párrafo de la disposición transitoria cuarta, violentando tal vez "su condición de transitoria", permite plantear «indefinidamente» el tema de la incorporación de Navarra a la Comunidad Autónoma Vasca ${ }^{236}$. En efecto, de acuerdo con el mismo, si la iniciativa no prosperase, podria volverse a reproducir siempre que no fuera en el mismo «período de mandato del Órgano Foral competente», y en todo caso cuando hubiera transcurrido un plazo mínimo de cinco años.

Finalmente, queremos recordar que el artículo 47-2 del Estatuto de Autonomía del País Vasco ha establecido, en líneas generales, el procedimiento que deberá seguirse una vez que se hayan cumplido los dos trámites que integran, según la disposición transitoria cuarta de la Constitución, la fase de iniciativa del proceso de incorporación (esto es, la aprobación por mayoría absoluta del Parlamento de Navarra y el referéndum afirmativo entre los electores inscritos en los censos de esta provincia). Sin entrar ahora en el análisis de este procedimiento ${ }^{237}$, duramente criti-

${ }^{234}$ Cfr. Enrique Linde Paniagua y Miguel Herrero Lera: «El referéndum en la Constitución...», op. cit., p. 45.

235 Ibidem.

236 Cfr. Joaquín Tomas Villarroya: «Proceso autonómico...», op. cit., p. 60.

${ }^{237}$ El artículo 47-2 del Estatuto de Euskadi, ubicado en el título dedicado a su reforma, dice que «en el caso de que se produjera la hlpótesis prevista en la disposición transitoria cuarta de la Constitución, el Congreso y el Senado, en sesión conjunta y siguiendo el procedimiento reglamentario que de común acuerdo determinen, establecerán, por mayoria absoluta, qué requisitos de los establecidos en el artículo 46 (que regula el procedimiento ordinario de reforma) se aplicarán para la reforma del Estatuto, que deberán en todo caso incluir la aprobación del Organo Foral competente, la aprobación mediante ley orgánica, por las Cortes Generales, y el referéndum del conjunto de los territorios.afectados». 
cado por el profesor TOMÁS VILLARROYA ${ }^{238}$, lo que sí queremos destacar es que deberá finalizar con un nuevo referéndum que, según reza el inciso final del citado precepto, deberá ser en este caso «del conjunto de los territorios afectados" ${ }^{239}$.

\subsection{Referéndum municipal}

Para finalizar la exposición de las diversas modalidades de referéndum previstas en el ordenamiento constitucional español, debemos referirnos a las consultas populares de ámbito municipal. En efecto, aunque la Constitución no las reconoce expresamente, su admisión en nuestro sistema político parece bastante evidente en virtud de lo dispuesto en el articulo 149-1-32. ${ }^{a}$ de la misma ${ }^{240}$. Además, por si quedaba alguna duda, la disposición adicional de la temprana Ley Orgánica del Referéndum precisó que los preceptos de dicha Ley «no alcanzan en su regulación a las consultas populares que puedan celebrarse por los Ayuntamientos, relativas a asuntos relevantes de indole municipal, en sus respectivos territorios, de acuerdo con la legislación de Régimen Local, y a salvo, en todo caso, la competencia exclusiva del Estado para su autorización». A pesar de que esta disposición excluye a los referéndums municipales del ámbito de aplicación de la Ley Orgánica $2 / 1980$, los reconoce de forma inequívoca y además, indirectamente, precisa algunos aspectos de esta modalidad referendaria. Ha sido, sin embargo, la Ley Reguladora de las Bases del Régimen Local, de 2 de abril de $1985^{241}$, la que ha fijado los caracteres esenciales de las consultas populares municipales. Su artículo 71 , situado dentro del capítulo dedicado a la «información y participación ciudadanas», está redactado con el siguiente tenor: «De conformidad con la legislación del Estado y de la Comunidad Autónoma, cuando ésta tenga competencia estatutariamente atribuida para ello, los Alcaldes, previo acuerdo por mayoría absoluta del Pleno y autorización del Gobierno de la Nación, podrán someter a consulta popular aquellos asuntos de la competencia propia

"23a El profesor Joaquín TOMÁs VILLARRoYa («Proceso autonómico...", op. cit., p. 61) ha comentado el artículo 47-2 del Estatuto vasco en los siguientes términos: «asume la regulación de un tema que debiera corresponder, principalmente, a Navarra; prevé la reunión conjunta del Congreso y del Senado en un supuesto que la Constitución no contempla; encomienda a las dos Cámaras la fijación de un procedimiento indeterminado; le permite seleccionar los requisitos fijados en el artículo 46 del mismo Estatuto".

${ }_{239}$ Esta precisión final resulta, según el profesor Joaquín Tomás ViLLARROYA («Proceso autonómico...", op. cit., p. 61), dudosamente constitucional, pues parece estar en "contradicción directa” con el artículo $151-2,4 .^{\circ}$ y $5 .^{\circ}$ de la Ley Fundamental, que exige que el Estatuto sea aprobado en cada provincia.

${ }_{240}$ El artículo 149-1-32." de la Constitución ofrece la siguiente redacción: "El Estado tiene competencia exclusiva sobre las siguientes materias: (...) 32." Autorización para la convocatoria de consultas populares por vía de referéndum».

${ }^{241}$ Ley 7/1985, de 2 de abril, Reguladora de las Bases del Régimen Local (Boletín Oficial del Estado de 3 de abril de 1985). 
municipal y de carácter local que sean de especial relevancia para los intereses de los vecinos, con excepción de los relativos a la Hacienda Local» ${ }^{242}$.

Analizando estos dos preceptos - la disposición adicional de la Ley Orgánica del Referéndum y el artículo 71 de la Ley de Bases del Régimen Local- descubrimos cuáles son los aspectos más destacados de los referéndums municipales:

- En primer lugar, vemos que sólo pueden someterse a consulta popular los asuntos especialmente relevantes de índole municipal, con lo cual es evidente que deberán excluirse los referéndums que recaigan sobre materias que no sean de la competencia de los Ayuntamientos y aquellos otros cuyo resultado pudiera tener repercusiones supramunicipales ${ }^{243}$.

- En segundo lugar, constatamos que hay un límite por razón de la materia de carácter absoluto: los asuntos relativos a la Hacienda Local, aunque tengan especial relevancia para los vecinos, no podrán someterse al veredicto popular. La justificación de esta exclusión hay que buscarla en la particular naturaleza de los temas fiscales, especialmente aptos para su utilización demagógica.

- En tercer lugar, observamos que, para que un Alcalde pueda someter a consulta popular un asunto municipal, es preciso el acuerdo previo del Pleno del Ayuntamiento por mayoría absoluta y la autorización del Gobierno de la Nación. No pueden negarse, a nuestro juicio, algunas coincidencias procedimentales con el referéndum consultivo consagrado en el artículo 92 de la Constitución, que exige —como sabemos- la autorización del Congreso de los Diputados por mayoría absoluta ${ }^{244}$.

- Finalmente, en cuarto lugar, se determina que el ámbito de los referéndums que celebren los Ayuntamientos será el de «sus respectivos territorios», quedando en la penumbra la posibilidad de celebrar consultas de ámbito comarcal, provincial o regional ${ }^{245}$.

${ }^{242}$ El artículo 18 de la Ley Reguladora de las Bases del Régimen Local precisa que: "1. Son derechos y deberes de los vecinos: (...) f) Pedir la consulta popular en los términos previstos en la Ley". A nuestro juicio, se trata de una mera concreción del genérico derecho de petición consagrado en el artículo 29-1 de la Carta Magna, sin que tal solicitud vincule juridicamente a los órganos municipales.

${ }^{243}$ Cfr. Juan Alfonso Santamaria PaStor: “Artículo 92», op. cit., p. 1320.

${ }^{244}$ Con anterioridad, los profesores Linde Paniagua y Herrero Lera habian defendido que la modalidad de los referéndums municipales «está comprendida en el referéndum consultivo del articulo 92». Cfr. Enrique Linde Paniagua y Miguel Herrero Lera: "Comentario a la Ley...", op. cit., p. 94; Enrique LINDE PANIAGUA: «Artículo 92...», op. cit., p. 381.

${ }_{245}$ A pesar del silencio legal, se inclinan por admitir esta posibilidad, entre otros, los siguientes autores: Luis AGUIAR DE LUQUE: «La Ley Orgánica de...», op. cit., p. 168; Enrique LINDE Paniagua y Miguel Herrero Lera: «Comentario a la Ley...», op. cit., p. 94. 
Por otra parte, debemos precisar que algunos estatutos de autonomía se han hecho eco de la posibilidad de que se celebren referéndums municipales, asumiendo competencias en esta materia. A título de ejemplo, recordemos que el artículo 15-2 del Estatuto de Andalucía afirma que «corresponde a la Comunidad Autónoma el desarrollo legislativo del sistema de consultas populares locales en el ámbito de Andalucía, de conformidad con lo que dispongan las leyes a que se refiere el apartado 3 del artículo 92 y el número 1 y 32 del artículo 149-1 de la Constitución, correspondiendo al Estado la autorización de su convocatoria". Cláusulas del mismo tenor pueden verse en el artículo 10-2 del Estatuto de Cataluña, en el artículo 321-8 del Estatuto de Valencia y en el artículo 31-3 del Estatuto de Canarias.

A juicio del profesor TORRES DEL MORAL, estos referéndums municipales «darán a los ciudadanos la oportunidad de autogobierno en los problemas más próximos y presumiblemente más conocidos. La vieja idea de que la democracia directa sólo es posible o resulta más viable en las comunidades reducidas puede tener aquí su plasmación más evidente " ${ }^{246}$.

\section{El extraordinario protagonismo de los partidos políticos en los procesos referendarios. Valoración crítica}

El profesor AGUIAR DE LUQUE defendió, hace ya algunos años, la tesis de que las instituciones de democracia directa en general, y el referéndum en particular, tienen, al menos a nivel teórico, un «claro significado antipartidista» ${ }^{247}$. Fundamentaba esta posición en base a tres consideraciones. Por una parte, porque la consulta directa comporta una «marginación del cauce parlamentario», que es el marco natural de desarrollo de las formaciones políticas. Por otra parte, porque supone una forma de plantear y resolver los problemas «al margen del sistema de partidos». $Y$ en tercer lugar, porque los ciudadanos son mucho menos disciplinados, ante las directrices de los partidos, en los referéndums que en las consultas electorales. Respecto a este último punto, es ilustrativo el razonamiento del profesor SÁNCHEZ AGESTA, cuando señala que «no ha dejado de ser picante el contraste entre la opinión que se forma y se manifiesta a través de los partidos políticos, y las opiniones que ha refrendado el pueblo cuando ha expresado directamente su opinión en una consulta. De una manera patente - sigue diciendo este autor - la clientela electoral de los partidos no ha seguido las indicaciones o las actitudes que los partidos adoptaban ante los problemas planteados en el referéndum» ${ }^{248}$. En esta misma línea, está fresco en nuestra memoria el Ilamativo contraste entre

246 Cfr. Antonio Torres del. Moral: Principios..., op. cit., vol. I, p. 128.

${ }_{247}$ Cfr. Luis AguIAR DE LUQUE: Democracia..., op. cit., p. 316.

248 Cfr. Luis SANCHEZ AgESTA: «Prólogo», op. cit., p. XXII. 
los buenos resultados obtenidos por el «no» en el referéndum sobre la permanencia de España en la Alianza Atlántica, y el escaso apoyo popular que - tres meses más tarde- obtuvieron los partidos políticos que habian propugnado dicha respuesta negativa.

A pesar de que la institución del referéndum puede tener efectivamente algunas connotaciones antipartidistas, lo cierto es que -como afirmaba gráficamente el profesor PÉREZ SERRANO- el peligro más importante es precisamente el contrario, esto es, que el referéndum sufra «la invasión morbosa del partidismo, que da las respuestas, como ofrece candidatos cuando de elegir se trata» ${ }^{249}$. Y muy posiblemente esta «invasión morbosa del partidismo", que denunciaba Pérez Serrano, se ha producido en la legislación que regula la institución del referéndum en nuestro sistema constitucional, especialmente a través de tres preceptos de la Ley Orgánica 2/1980: los artículos 11-2, 14-1 y 19-5. Veamos, brevemente, su contenido.

a) El artículo 11-2 afirma que las facultades atribuidas en el régimen electoral general «a los partidos, federaciones, coaliciones y agrupaciones de electores se entenderán referidas a los grupos políticos con representación parlamentaria, o a los que hubieran obtenido, al menos, un 3 por 100 de los sufragios válidamente emitidos en el ámbito a que se refiera la consulta, en las últimas elecciones generales celebradas para el Congreso de los Diputados".

b) La restricción que establece el primer apartado del artículo 14 de la Ley Orgánica del Referéndum es todavía mayor. De acuerdo con el mismo, sólo tienen derecho a espacios gratuitos en los medios de difusión de titularidad pública «los grupos políticos con representación en las Cortes Generales».

c) Finalmente, de acuerdo con el artículo 19-5 de la citada Ley Orgánica, sólo están «legitimados para interponer el recurso contenciosoelectoral o para oponerse a los que se interpongan, los representantes de los grupos políticos mencionados" en el segundo apartado del artículo 11 de dicha Ley. Es decir, los representantes de los grupos políticos con representación parlamentaria y los de aquellos grupos que en las últimas elecciones generales celebradas para la Cámara Baja hubieran obtenido, al menos, un 3 por ciento de los votos válidos emitidos ${ }^{250}$.

${ }^{249}$ Cfr. Nicolás Pérez Serrano: Tratado... op. cit., pp. 702-703.

250 De acuerdo con el segundo párrafo del artículo 19-5, en los referéndums sobre iniciativa del proceso autonómico, estaban también legitimadas las corporaciones locales en cuyo ámbito territorial se hubiera celebrado el referéndum. 
A tenor de esta normativa, se puede afirmar que los legisladores contemplaron el referéndum, más que como un mecanismo "de participación directa y ocasional de los ciudadanos en las decisiones públicas", como «un instrumento subsidiario, que no circunstancialmente sustitutorio, de los partidos politicos" ${ }^{251}$. El profesor CRUZ VILLALÓN ha criticado con extrema dureza esta regulación. A su juicio, «el golpe más grave que la Ley Orgánica ha venido a infligir al referéndum consultivo es el haber otorgado a los partidos el monopolio del protagonismo en toda la operación referendaria, como si de unas elecciones se tratase». De esta manera, sigue razonando este autor, "la consulta pierde en definitiva su razón de ser, desde el momento en que las alineaciones vuelven a pasar por las divisiones de partidos y, muy concretamente, en base al espectro parlamentario» ${ }^{252}$.

En nuestra opinión, es innegable que la omnipresencia de los partidos políticos - por reacción frente al régimen anterior- ha invadido todos los ámbitos de nuestro sistema constitucional. Incluso instituciones como el referéndum, cuyo máximo valor estriba en la posibilidad de que la voluntad popular se exprese directamente sin intermediarios, se han visto parcialmente desnaturalizadas por esta «invasión morbosa del partidismo", a la que hace cincuenta años ya aludía con preocupación el profesor PÉREZ SERRANO.

${ }^{25 i}$ Cfr. Enrique Linde Paniagua y Miguel Herrero Lera: «Comentario a la Ley...», op. cit., p. 88.

${ }^{252}$ Cfr. Pedro Cruz VILLalón: «El referéndum...», op. cit., p. 164. En su opinión, el desarrollo del referéndum consultivo requiere «la formación y promoción de organizaciones ad hoc que aglutinen a los ciudadanos en razón de su posición ante la cuestión planteada». 


\section{BIBLIOGRAFÍA EN TORNO A LA INSTITUCIÓN DEL REFERÉNDUM}

AgUIAR DE LUQUe, Luis: Democracia directa y Estado constitucional, Edersa, Madrid 1977.

-: «Referéndum», en Diccionario del sistema político español (dirigido por J. J. González Encinar), Akal, Madrid 1984, pp. 791-798.

-: "Referéndum y régimen parlamentario en las democracias de masas", en EI control parlamentario del Gobierno en las democracias pluralistas, Labor, Barcelona 1978, pp. 408-418.

-: «La Ley Orgánica de Referéndum: Un comentario» en Revista de la Facultad de Derecho de la Universidad Complutense, núm. 58, 1980, pp. 167-173.

-: «Sobre el referéndum», en Informaciones Politicas, 24 de junio de 1978.

Aguiar de LuQue, Luis y ARAgon Reyes, Manuel: «Consideraciones en torno a los resultados del referéndum del 15 de diciembre de 1976 en Madrid», en Revista del Instituto de la Opinión Pública, núm. 48, 1977.

Alvarez Conde, Enrique: El régimen politico español, Tecnos, Madrid 1983.

AlzAga VILLAAMIL, Óscar: La Constitución española de 1978, Ediciones del Foro, Madrid 1978.

ARNALdo AlCubilla, Enrique: "Crónica electoral», en Revista de las Cortes Generales, núm. 8, 1986, pp. 343-370.

BAssols Coma, Martín: «Derecho electoral», en Revista de las Cortes Generales, núm. 1, 1984, pp. 284-291.

-: «Derecho electoral», en Revista de las Cortes Generales, núm. 3, 1984, pp. 227232.

BAtelLI, M.: Les institutions de démocratie directe en droit suisse et comparé moderne, Sirey, Paris 1932.

BetTINELLI, E.: «Itineraria della razionalizzazione della convenzione antireferendaria», en Politica del Diritto, IX, 5, 1978, pp. 513-559.

BIscarettI dI Ruffia, Paolo: Derecho Constitucional, Tecnos, Madrid 1973. 
BORTOLI, Gilbert: Sociologia del referéndum en la Francia moderna, L.G.D.J., París 1965.

Boulssou, M.: «La pratique référendaire en France", en Revue Internationale de Droit Comparé, XXVIII, 2, 1976, pp. 265-286.

CADART, J.: «Les inconvénients et les dangers plebiscitaires du référendum d'initiative présidentielle et gouvernementale en France dépuis 1958 et les remèdes désiderables", en Revue Internationale de Droit Comparé, XXVIII, 2, 1976.

CARETTI, P.: "Stato di attuazione degli statuti regionali in tema di iniziativa popolare e referendum», en Rivista di Diritto Pubblico, 1972, pp. 1017-1028.

Carré de Malberg, Raymond: "Considérations théoriques sur la question de la combinaison du référendum avec le parlementarisme", en Revue du Droit Public, núm. 2 de 1931, pp. 225-244.

CONDORCET, Marques de: Sur la nécessité de faire ratifier la Constitution par les citoyens, Oeuvres completes, tomo XV, Paris 1804.

Corcuera Atienza, Javier y Pérez Calvo, Alberto: «En torno al referéndum del Estatuto de Autonomia del País Vasco. Notas sobre el subsistema de partidos vascos", en Revista de Estudios Politicos, núm. 12, 1979, pp. 179-196.

CRUZ VILLALÓN, Pedro: «El referéndum consultivo como modelo de racionalización constitucional», en Revista de Estudios Políticos, núm. 13, 1980, pp. 145-168.

dE Esteban, Jorge: «La participación politica en el ordenamiento constitucional español», en Cuadernos para el Diálogo, núm. extraordinario XXXV, junio 1973.

de Esteban, Jorge y Lopez GuerRa, Luis: El régimen constitucional español, Labor Universitaria, Barcelona 1980-1982, vols. I y II.

-: «Referéndum consultivo y decisión política», en el diario El Pais, 30 de enero de 1986, pp. 11-12.

de Reparaz y Astein, Julián: El referéndum, Hijos de Reus, Madrid 1917.

del Castillo Vera, Pilar: «Referéndum del Estatuto de Autonomía en el País Vasco», en Revista del Departamento de Derecho Político, núm. 5, invierno 1979-1980, pp. 201-211.

-: «Referéndum en Andalucia en aplicación del artículo 151 de la Constitución», en Revista del Departamento de Derecho Politico, núm. 6, primavera 1980, pp. 175-179.

Denouin, J. M.: Référendum et plébiscite. Essai de théorie générale, L.G.D.J., Paris 1976.

Diвоuт, P.: “Référendum et système parlementaire: Étude de la consultation référendaire du 5 juin 1975 dans le Royaume Unim, en Revue Internationale de Droit Comparé, 2, 1976, pp. 291-323. 
Duval, H. y otros: Référendum et plébiscite, Armand Colin, Paris 1970.

Editorial del Diario «El Pals»: “Referéndum o jeroglífico», en el diario El Pais, 30 de enero de 1980.

EDITORIAL DEL DIARIO "YA»: «¿Por qué no un plebiscito?», en el diario Ya, 3 de abril de 1976.

Equipo de Sociología Electoral (Universidad Autónoma de Barcelona): «El referéndum del Estatuto de Autonomía en Cataluña», en Revista de Estudios Pollticos, núm. 12, 1979, pp. 197-213.

-: “El referéndum del 12 de marzo de 1986 sobre la permanencia de España en la OTAN y sus consecuencias para el sistema político", en Revista de Estudios Políticos, núm. 52, 1986, pp. 183-215.

Friedrich, Carl J.: La démocratie constitutionnelle, P.U.F., Paris 1958.

-: Gobierno constitucional y democracia, Instituto de Estudios Politicos, Madrid 1975 , vols. I y II.

Garrigou-Lagrange, Jean-Marie: «Le dédoublement constitutionnel. Essai de rationalisation de la pratique référendaire de la $V$ République", en Revue du Droit Pub/ic, núm. 4 de 1969, pp. 641-685.

Garrorena Morales, Angel: "Teoria y práctica española del referéndum», en Anales do la Universidad de Murcia, vol. XXXI, núm. 3-4, 1977.

-: El Estado español como Estado social y democrático de Derecho, Tecnos, Madrid 1984.

GIACCARDI, Giorgio: «Il referendum nelle regioni a statuto ordinario», en I/ Foro Amministrativo, III, 1971, pp. 791-809.

Hauriou, André: Droit Constitutionnel et institutions politiques, Montchrestien, Paris 1968.

Hermosa Andúar, Antonio: "El camino de Rousseau. De la democracia directa a la democracia representativa", en Revista de Estudios Politicos, núm. 50, 1986, pp. 101-141.

Hernandez Lafuente, Adolfo: “Los referéndums de autonomía en la Il República», en Revista de Estudios Políticos, núm. 5, 1978, pp. 97-119.

Jiménez de Parga, Manuel: «Referéndum y plebiscito", en Diario de Barcelona, 15 de agosto de 1976.

LABOA, Juan M. y VANACLOCHA, Francisco J.: «El referéndum en España», en Historia 16, núm. 7 , noviembre 1976, pp. 24-30. 
Linde Paniagua, Enrique: "Anotaciones a los Decretos-leyes de convocatoria de los referéndums autonómicos en el País Vasco y Cataluña: vigencia de la Constitución y reserva de ley orgánica», en Revista de Administración Pública, núm. 89, 1979, pp. 411-417.

-: "Artículo 92. Referéndum", en Comentarios a las Leyes Politicas. Constitución española de 1978 (dirigidos por Óscar Alzaga Villaamil), Edersa, Madrid 1985, tomo VII, pp. 367-403.

Linde Paniagua, Enrique y Herrero Lera, Miguel: «El referéndum: de las Leyes Fundamentales al Anteproyecto de Constitución", en Revista de Estudios Políticos, núm. 2, 1978, pp. 87-106.

-: “El referendum en la Constitución española de 1978", en Boletín Informativo del Departamento de Derecho Político, núm. 3, primavera 1979, pp. 17-48.

-: "Comentario a la Ley Orgánica de modalidades de referéndum", en Revista del Departamento de Derecho Politico, núm. 6, primavera 1980, pp. 83-105.

LOEWENSTEIN, Karl: Teoría de la Constitución, Ariel, Barcelona 1976.

LÓPEZ GUERRA, Luis: «Algunas notas sobre los resultados de los referéndums españoles de 1947 y 1966». Trabajo mecanografiado.

López Guerra, Luis y Elizalde Pérez, José Maria: Apuntes de Derecho Político I, Universidad de Extremadura, Facultad de Derecho, Departamento de Derecho Político, Cáceres 1979-1980, vol. II.

LuCAS Verdú, Pablo: «Abstención y referéndum», en el diario El Pais, 5 de diciembre de 1976.

Martínez Cuadrado, Miguel: «Representación. Elecciones. Referéndum», en La España de los años 70, vol. III (El Estado y la política), Moneda y Crédito, Madrid 1974.

Mellado Prado, Pilar: «El referéndum sobre el Estatuto de Autonomía andaluz», en Revista de Derecho Politico, núm. 13, primavera 1982, pp. 213-215.

MIRKINE-GUETZEVITCH, Boris: "Le référendum et le parlementarisme dans les nouvelles Constitutions européennes", en Annuaire de I'Institut International de Droit Public, Paris 1931.

Moret y Prendergast, Segismundo: Discurso leído el día 9 de noviembre de 1895 en el Ateneo Cientifico y Literario de Madrid sobre el tema del referéndum, Esti. Ip. Sucesores de Ribadeneyra, Madrid 1895.

Muñoz Machado, Santiago: Derecho Público de las Comunidades Autónomas I, Civitas, Madrid 1982.

Ollero ButLer, Fernando: "El referéndum para la autonomía de Cataluña», en Revista del Departamento de Derecho Político, núm. 5, invierno 1979-1980, pp. 213-225. 
Ortega Álvarez, Luis: "La inconstitucionalidad de la reforma de la Ley Orgánica de Referéndum", en Revista de Administración Pública, núm. 97, 1982, pp. 171-204.

PADIRAC, R.: “Les institutions de democratie directe en Italie», en Revue Internationale de Droit Comparé, julio 1972.

Pérez Serrano, Nicolás: Tratado de Derecho Político, Civitas, Madrid 1976.

RAMIREZ JIMENEZ, Manuel: «Democracia directa y Constitución: problemática y desarrollo legislativo", en El desarrollo de la Constitución española de 1978, Pórtico, Zaragoza 1982, pp. 15-39.

-: «Participación y pluralismo en la Constitución de 1978», en Estudios sobre la Constitución española de 1978, Pórtico, Zaragoza 1979, pp. 55-69.

-: La participación política, Tecnos, Madrid 1985.

Rescigno, U.: «Referendum e istituzioni», en Politica del Diritto, IX, 5 (1978), pp. 605627.

Ripollés Serrano, María Rosa: "Notas acerca de la Ley Orgánica sobre regulación de las distintas modalidades de referéndum", en Comentarios sobre la Constitución española de 1978, Universidad de Valencia, Valencia 1980, pp. 313-339.

RuINI, M.: /l referendum popolare e la revisione della Costituzione, Milán 1953.

Ruiz del Castillo, Carlos: Manual de Derecho Político, Reus, Madrid 1939.

SANCHEZ AgeSta, Luis: «Prólogo» a la obra de Luis Aguiar de Luque Democracia directa y Estado constitucional, Edersa, Madrid 1977, pp. XVII-XXIV.

-: «¿Un referéndum?», en el diario Ya, 23 de abril de 1976.

SANCHEZ GonzÁLEZ, Santiago: "Referendum sobre el Estatuto de Autonomia de Galicia», en Revista de Derecho Politico, núm. 9, primavera 1981, pp. 219-220.

SANTAMARIA Ossorio, Julián: «Participación política y democracia directa», en Estudios de Ciencia Politica y Sociología. Homenaje al profesor Carlos Ollero, Madrid 1972, pp. 743 y siguientes.

-: «La iniciativa popular y el referéndum», en el diario El Pais, 14 de junio de 1978, p. 12.

Santamaria PAstor, Juan Alfonso: “Artículo 92", en Comentarios a la Constitución (dirigidos por F. Garrido Falla), Civitas, Madrid 1985, pp. 1312-1323.

Scudeiro, M.: // referendum nell'ordinamento regionale, Nápoles 1971.

SICARD, G.: «Référendum et plébiscite dans l'histoire de France», en Revue de Sciences Politiques, février-mars-avril 1964, pp. 85-116. 
Tomás VILlarroYa, Joaquín: «Proceso autonómico y observancia de la Constitución»; en Revista Española de Derecho Constitucional, núm. 15, 1985, pp. 25-64.

-: "Comentario al libro El régimen constitucional español 1", en Revista Española de Derecho Constitucional, núm. 3, 1981, pp. 335-352.

TORRES DEL MORAL, Antonio: «Democracia y representación en los origenes del Estado constitucional», en Revista de Estudios Politicos, núm. 203, 1975, pp. 145-212.

-: Principios de Derecho Constitucional español, Atomo Ediciones, Madrid 19851986, vols. I y II.

-: «La participación política a través de las instituciones de democracia directa», en La participación, Estudi General de Lleida, Barcelona 1985, pp. 23-44.

URIBE VARGAS, D.: El referéndum; ensayo sobre la democracia semidirecta, Bogotá 1967.

VIDAL BENEYTO, José: Elecciones municipales y referéndum, Imp. Tanagra, Madrid 1966. 